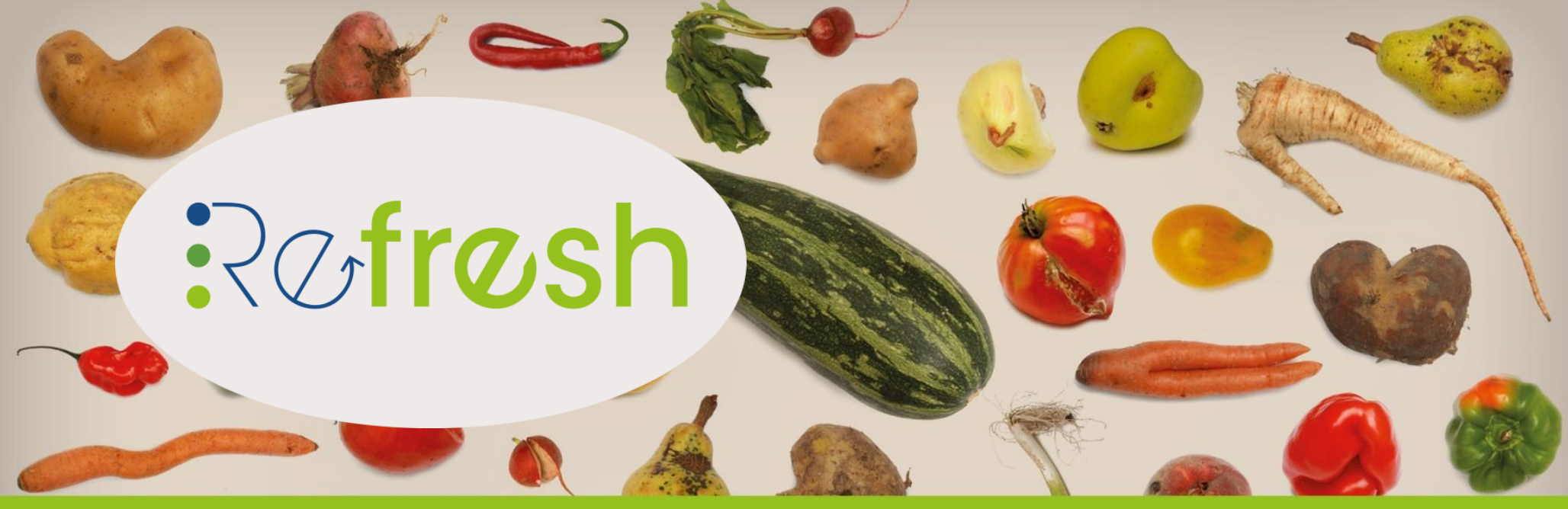

\title{
D4.6 - Pan-European scenarios of food waste levels
}




\section{Authors}

Matteo Masotti, University of Bologna

Gavin Stewart, University of Newcastle

Andrew Close, University of Newcastle

Marco Setti, University of Bologna

Matteo Vittuari, University of Bologna

With thanks to:

Hilke Bos-Brouwers, Wageningen Food \& Biobased Research

Lusine Aramyan, Wageningen Economic Research, formerly LEI

Katja Logatcheva, Wageningen Economic Research, formerly LEI

Karin Östergren, Ri.Se

Erica Van Herpen, Wageningen University

Stephanie Wunder, Ecologic Institute

Project coordination and editing provided by Ecologic Institute.

This document is available on the Internet at: https://eu-refresh.org/

Document title D4.6 - Pan-European scenarios of food waste levels

Work Package WP4

Document Type Deliverable

Date June, 2019

Document Status Final draft

ISBN number 978-94-6395-089-3

DOI number $\quad 10.18174 / 498708$

\section{Acknowledgments \& Disclaimer}

This project has received funding from the European Union's Horizon 2020 research and innovation programme under grant agreement No 641933.

Neither the European Commission nor any person acting on behalf of the Commission is responsible for the use which might be made of the following information. The views expressed in this publication are the sole responsibility of the author and do not necessarily reflect the views of the European Commission.

Reproduction and translation for non-commercial purposes are authorised, provided the source is acknowledged and the publisher is given prior notice and sent a copy. 


\section{Table of Contents}

$\begin{array}{ll}\text { Executive summary } & 7\end{array}$

1 Introduction $\quad 9$

2 European Union $\quad 12$

3 Austria 16

$\begin{array}{llr}4 \text { Belgium } & 18\end{array}$

5 Bulgaria $\quad 21$

6 Croatia 23

7 Czech Republic $\quad 25$

8 Cyprus 28

9 Denmark 29

$\begin{array}{ll}10 \text { Estonia } & 31\end{array}$

11 Finland $\quad 32$

12 France $\quad 34$

13 Germany $\quad 39$

$\begin{array}{ll}14 \text { Greece } & 44\end{array}$

$\begin{array}{ll}15 \text { Hungary } & 47\end{array}$

$\begin{array}{ll}16 \text { Ireland } & 50\end{array}$

17 Italy

$\begin{array}{ll}18 \text { Lithuania } & 56\end{array}$

$\begin{array}{ll}19 \text { Luxembourg } & 58\end{array}$

$\begin{array}{ll}20 \text { Latvia } & 59\end{array}$

$\begin{array}{ll}21 \text { Malta } & 60\end{array}$

$\begin{array}{ll}22 \text { The Netherlands } & 61\end{array}$

$\begin{array}{ll}23 \text { Poland } & 64\end{array}$ 


\section{List of Tables}

Table 3-1: EU28 - parameters for FW estimation at European level

Table 3-2: EU28 -FW estimation at European level

Table 4-1: Austria - parameters for FW estimation at regional level

Table 4-2: Austria - FW estimation at regional level

Table 5-1: Belgium - parameters for FW estimation at regional level

Table 5-2: Belgium - FW estimation at regional level

Table 6-1: Bulgaria - parameters for FW estimation at regional level

Table 6-2: Bulgaria - FW estimation at regional level

Table 7-1: Croatia - parameters for FW estimation at regional level

Table 7-2: Croatia - FW estimation at regional level

Table 8-1: Czech Republic - parameters for FW estimation at regional level

Table 8-2: Czech Republic - FW estimation at regional level

Table 9-1: Cyprus - parameters for FW estimation at regional level

Table 9-2: Cyprus - FW estimation at regional level

Table 10-1: Denmark - parameters for FW estimation at regional level

Table 10-2: Denmark - FW estimation at regional level

Table 11-1: Estonia - parameters for FW estimation at regional level

Table 11-2: Estonia - FW estimation at regional level

Table 12-1: Finland - parameters for FW estimation at regional level 
Table 12-2: Finland - FW estimation at regional level

Table 13-1: France - parameters for FW estimation at regional level

Table 13-2: France - FW estimation at regional level

Table 14-1: Germany - parameters for FW estimation at regional level

Table 14-2: Germany - FW estimation at regional level

Table 15-1: Greece - parameters for FW estimation at regional level

Table 15-2: Greece - FW estimation at regional level

Table 16-1: Hungary - parameters for FW estimation at regional level

Table 16-2: Hungary - FW estimation at regional level

Table 17-1: Ireland - parameters for FW estimation at regional level

Table 17-2: Ireland - FW estimation at regional level

Table 18-1: Italy - parameters for FW estimation at regional level

Table 18-2: Italy - FW estimation at regional level

Table 19-1: Lithuania - parameters for FW estimation at regional level

Table 19-2: Lithuania - FW estimation at regional level

Table 20-1: Luxembourg - parameters for FW estimation at regional level

Table 20-2: Luxembourg - FW estimation at regional level

Table 21-1: Latvia - parameters for FW estimation at regional level

Table 21-2: Latvia - FW estimation at regional level

Table 22-1: Malta - parameters for FW estimation at regional level

Table 22-2: Malta - FW estimation at regional level

Table 23-1: The Netherlands - parameters for FW estimation at regional level 61

Table 23-2: the Netherlands - FW estimation at regional level

Table 24-1: Poland - parameters for FW estimation at regional level

Table 24-2: Poland - FW estimation at regional level

Table 25-1: Portugal - parameters for FW estimation at regional level

Table 25-2: Portugal - FW estimation at regional level

Table 26-1: Romania - parameters for FW estimation at regional level

Table 26-2: Romania - FW estimation at regional level

Table 27-1: Slovenia - parameters for FW estimation at regional level 
Table 27-2: Slovenia - FW estimation at regional level

Table 28-1: Slovakia - parameters for FW estimation at regional level 76

Table 28-2: Slovakia - FW estimation at regional level 77

Table 29-1: Spain - parameters for FW estimation at regional level 78

Table 29-2: Spain - FW estimation at regional level 80

Table 30-1: Sweden - parameters for FW estimation at regional level 82

Table 30-2: Sweden - FW estimation at regional level 84

Table 31-1: United Kingdom - parameters for FW estimation at regional level 86

Table 31-2: United Kingdom - FW estimation at regional level

\section{List of Figures}

Figure 1: estimated FW per household per week in the EU 14

Figure 2: estimated FW per household in Austrian regions 17

Figure 3: estimated FW per household in Belgian regions 19

Figure 4: estimated FW per household in Bulgarian regions 22

Figure 5: estimated FW per household in Croatian regions 23

Figure 6: estimated FW per household in Czech regions 27

Figure 7: estimated FW per household in Danish regions 30

Figure 8: estimated FW per household in Finnish regions 33

Figure 9: estimated FW per household in French regions 37

Figure 10: estimated FW per household in German regions 41

Figure 11: estimated FW per household in Greek regions 45

Figure 12: estimated FW per household in Hungarian regions 48

Figure 13: estimated FW per household in Irish regions 51

Figure 14: estimated FW per household in Italian regions 54

Figure 15: estimated FW per household in Lithuanian regions 57

Figure 16: estimated FW per household in Dutch regions 62

Figure 18: estimated FW per household in Polish regions 66

Figure 19: estimated FW per household in Portuguese regions 69

Figure 20: estimated FW per household in Romanian regions 73 
Figure 21: estimated FW per household in Slovenia regions

Figure 22: estimated FW per household in Slovakia regions

Figure 23: estimated FW per household in Spanish regions

Figure 24: estimated FW per household in Swedish regions

Figure 25: estimated FW per household in English regions

\title{
List of abbreviations
}

\author{
FW Food Waste \\ FSC Food Supply Chain \\ GDP Gross Domestic Product
}

NUTS 2 Nomenclature of territorial units for statistics 2

PPP Purchasing Power Parity 


\section{Executive summary}

REFRESH is an EU research project dedicated to contributing to the achievement of the Target 3 of Sustainable Development Goal 12, which aims to halve per capita food waste at the retail and consumer level as well as to reduce food losses along the food chain by 2030 . Partners across Europe are collecting data on methods to decrease or repurpose food waste.

In developed countries an estimated 30 to $40 \%$ of food is wasted. About half of this waste stems from consumers, while the remaining part is lost through the other phases of the Food Supply Chain (FSC): farm practices, transport and processing, and the retail sector (Godfray et al. 2010; Gustavsson et al. 2011). To meet target 12.3 of the Sustainable Development Goals, a better understanding of food waste drivers is needed, both at the consumer and at the retail level. More importantly, the effectiveness of interventions designed to reduce food waste at every level of the FSC needs to be assessed.

Research on food waste faces several issues. On one side, large number of factors influences the behaviour of the actors in the Food Supply Chain, on the other side, food waste research often lacks reliable data on the amounts of food wasted along FSC. These limitations can be overcome using a simulation approach to predict household food waste levels.

\section{Pan-European scenarios of food waste levels}

This work is part of a collection of reports on household food waste prediction for EU28, Member Countries and European Regions. The collection consists of a methodological report, REFRESH D4.8 - A roadmap to reduce food waste in Europe, which represents the theoretical base for two additional reports, REFRESH D4.6 Pan-European scenarios of food waste levels and REFRESH D4.7 A pan-European simulation of selected interventions, where food waste scenarios for EU28 and for each European Country are presented.

In particular, this work collects 29 single food waste scenarios (28 Country scenarios and a prediction scenario related to the whole EU-28). Scenarios, describing kilograms of food wasted every year by an average household, are based on predictions of food waste levels conducted considering the current values of different socioeconomic and demographic factors: GDP (euros at purchasing power parity), the national tertiary education rates, national employment rate, average household size and house ownership status. No external intervention aimed at reducing the quantity of food waste is considered. 


\section{Method and limitations}

Methodologies and results presented in this work are based on REFRESH D4.8 - $A$ roadmap to reduce food waste in Europe. These simulations represent a first attempt to develop food waste predictions in the European Union and its Member States. The roadmap, published on line ${ }^{1}$, includes a web-based user-friendly tool rooted on a Bayesian hierarchical mixed-effects modelling approach, derived from previous REFRESH works (REFRESH D4.3 Model integration - Integrated socioeconomic model on food waste and REFRESH D4.4 Behavioural Economics: Linking Bayesian and agent-based models to assess consumer food waste).

To overcome the data availability constraint and to gather data in a suitable format for the development of the model, UK data derived from WRAP (2013) relative to household food waste in UK in 2012 has been utilized. After a number of simulations this dataset proved to be the most reliable to address the needs of the hierarchical mixed-effects modelling approach.

The underlying assumption of this choice implies a general similarity between European countries. However, considering the complexity of factors driving households' behaviour and decisions concerning food consumption and management, trends in UK data may not accurately reflect household food waste variations elsewhere. Food waste behaviours are affected by several determinants concerning economic, cultural and social factors, which are in turn influenced by the community where consumers belong. Therefore, utilization of the UK dataset as a proxy to extend food waste data to other EU countries also represents a potential source of bias. In order to address this issue, a pan-European, standardized study design, - as also advocated by Reynolds et al., (2019)- may improve generality, facilitate interpretation, and provide more robust predictions of household food waste capturing underlying socio-economic characteristics at national and regional scales.

So, further research should focus on collecting reliable and validated data on food waste in different Regions and Countries, with the aim to better understand the local peculiarities of food waste habits, both at consumers and retail levels.

However, despite this limitation, the model provides a set of new and interesting information regarding the influence of socio-economic determinants on food waste generation, potentially suggesting some of the targets that policy interventions might consider to prioritize.

${ }^{1}$ https://refresh-determinants-of-consumers-food-waste.shinyapps.io/predicted food waste/ 


\section{Introduction}

Food waste (FW) is a widespread and complex problem, which relates to the functioning of the food supply chain (FSC) as a whole. Estimates suggest that, in the EU-28, annual FW amounts to 88 million tonnes, i.e. 173 kilograms per person (Stenmarck et al., 2016). Food waste has become a major global concern because of its diversified and interconnected implications on the different FSCs (Canali et al., 2016; Parfitt et al., 2010; Piras et al., 2016).

The generation of food waste stems from a complex set of interacting behaviours of both food consumers and suppliers. Therefore, systemic approaches might have the potential to capture this complexity in a more comprehensive and reliable manner (Grainger et al., 2018).

A combination of approaches based on Bayesian Networks (BN) and Agent Based Models (ABM) can represent an effective way to understand the drivers that underpin the FW phenomenon

While being powerful tools for the analysis of complex systems, these modelling approaches require reliable data to be able to produce robust predictions.

Following these approaches, integrated models of household food waste as an emergent property of a complex system were generated. Machine learnt Bayesian Networks and Agent Based Models were utilized to develop systems maps of the consumer food waste nexus. Through those models, different linkages were emphasised both in the retail environment and in the home predicted food waste. Therefore, modelling of consumer behaviour should not be restricted to a single environment and the key element for each of them should be identified.

Finally, an integrated whole-of-system modelling approach was built to allow the creation of a decision-relevant and dynamic support tool as base for the development of a road map to the reduction of European FW by $50 \%$ by 2030 .

A first version of the integrated model was developed in Grainger et al. (2018). As stated above, the use of a simulation approach is crucial for assessing food waste since empirical data are still limited in scale or have a high potential for bias (such as self-reported consumer food waste). This leads to high levels of uncertainty in the available data, additional to the complexity associated with understanding the socio-economic drivers of food waste.

Bayesian Networks (BNs) can incorporate uncertainty and complexity in the model structure, but they are less effective at incorporating behavioural factors (i.e. specific biases of single actors, and interactions among actors) and temporal dynamics (interactions among variables or actors across time). For these types of information, Agent-Based Models (ABMs) are much better suited. To represent food system complexity more accurately whilst incorporating interactions among and within actors (businesses, consumers, etc.), a BNs-ABMs dynamic interaction proved to be a suitable method (Grainger et al., 2018).

These modelling developments represented the basis for the structure of the REFRESH Roadmap, presented in REFRESH D4.8 - A roadmap to reduce food waste in Europe, which is focused on food waste generation at the household level and 
allows simulations - based on a Bayesian hierarchical mixed-effects modelling approach - that quantify the relationships between socioeconomic and demographic indicators and household food waste.

Starting from this roadmap, a web-based, user-friendly tool simulating household food waste generation at the Regional, National and European level has been developed. This web-based tool allows to simulate a number of different scenarios, based on a set of socioeconomic variables, such as income per capita, tertiary education rate and national employment rate.

\section{Methodological background}

This work is part of a collection of reports on household food waste prediction for EU28, Member Countries and European Regions. The collection consists of a methodological report, REFRESH D4.8 - A roadmap to reduce food waste in Europe, which represents the theoretical base for two additional reports, REFRESH D4.6 Pan-European scenarios of food waste levels and REFRESH D4.7 A pan-European simulation of selected interventions, where food waste scenarios both for EU28 and for each single European Country are presented.

Moreover, methodologies and results presented in REFRESH D4.8 - A roadmap to reduce food waste in Europe are built on the results presented in REFRESH D4.3 Model integration - Integrated socio-economic model on food waste and in REFRESH D4.4 Behavioural Economics: Linking Bayesian and agent-based models to assess consumer food waste.

\section{Limitations and future developments of the hierarchical mixed-effects modelling approach}

The hierarchical mixed-effects modelling approach utilized to develop these estimations represents a first attempt to predict food waste at the EU level using a simulation model and it had to face, among others, important limitations in terms of data availability on food waste amounts.

To overcome the data availability constraint in a format suitable for the development of the model, UK data derived from WRAP (2013) Household food and drink waste in the UK 2012 has been used. This choice is due to the statistical characteristics of WRAP dataset: while being UK specific, this data has the principal advantage of providing a validated measure of household food waste. Such a feature makes this dataset reliable for the simulation approach adopted in the roadmap, despite its limited territorial coverage.

The underlying assumption of this choice implies a general similarity between European countries. However, considering the complexity of factors driving households' behaviour and decisions concerning food consumption and management, trends in UK data may not accurately reflect household food waste variations elsewhere. Food waste behaviours are affected by several determinants concerning economic, cultural and social factors, which are often in turn influenced by the community where consumers belong. Therefore, utilization of the UK dataset as a proxy to extend food waste data to other EU countries represents also a potential source of bias. In order to address this likely source of bias, a panEuropean, standardized study design, - as also advocated by Reynolds et al. (2019) - may improve generality, facilitate interpretation, and provide more robust 
predictions of household food waste that capture underlying socio-economic characteristics at national and regional scales.

However, despite this limitation, the model provides a set of new information regarding the influence of socio-economic determinants on food waste generation. Furthermore, the model can suggest some of the targets that policy interventions might consider to prioritize.

To increase the reliability of the results obtained through the roadmap, future research should focus on obtaining more consistent national data on food waste and on the impact of food waste reduction interventions. Research on the impact of interventions is particularly urgent since there is a scarcity of reliable and solid quantitative data able to improve the predictive capacity of the model. 


\section{European Union}

According to 2017 Eurostat data, the EU population amounts to $\mathbf{5 1 1 , 3 7 3 , 2 7 8}$. The Gross Domestic Product (GDP) per capita on purchasing power parity is $\mathbf{2 9 , 5 0 0}$ euro at the European level, with consistent regional differences, ranging from $\mathbf{1 4 , 5 0 0}$ euro per capita in Bulgaria to $\mathbf{7 4 , 5 0 0}$ euro per capita in Luxemburg. There are $\mathbf{2 2 1}, \mathbf{4 3 0}, \mathbf{5 0 0}$ households, with an average size of $\mathbf{2 . 3}$ persons.

The average employment rate is $\mathbf{6 1 . 1 \%}$, while the level of tertiary education is $\mathbf{3 2 . 3 \%}$. Table 2-1 summarizes the baseline values disclosed on Eurostat data.

Table 2-1: EU28 - parameters for FW estimation at European level

\begin{tabular}{|c|c|c|c|c|c|}
\hline Country & $\begin{array}{l}\text { GDP } \\
\text { PPP } \\
\text { (Eur) }\end{array}$ & $\begin{array}{l}\text { Tertiary } \\
\text { education } \\
\text { level }\end{array}$ & $\begin{array}{l}\text { Median } \\
\text { age }\end{array}$ & Population & $\begin{array}{l}N^{\circ} \text { of } \\
\text { households }\end{array}$ \\
\hline Austria & 37,400 & $32.7 \%$ & 43.0 & $8,772,865$ & $3,915,500$ \\
\hline Belgium & 34,300 & $40.6 \%$ & 41.5 & $11,351,727$ & $4,761,700$ \\
\hline Bulgaria & 14,500 & $28.2 \%$ & 43.9 & $7,101,859$ & $2,905,400$ \\
\hline Cyprus & 25,000 & $44.1 \%$ & 37.4 & 854,802 & 321,200 \\
\hline $\begin{array}{l}\text { Czech } \\
\text { Republic }\end{array}$ & 26,400 & $24.3 \%$ & 41.9 & $10,578,820$ & $4,699,000$ \\
\hline Germany & 36,400 & $29.1 \%$ & 45.9 & $82,521,653$ & $40,722,600$ \\
\hline Denmark & 37,700 & $39.7 \%$ & 41.6 & $5,748,769$ & $2,395,900$ \\
\hline Estonia & 23,200 & $41.2 \%$ & 41.8 & $1,315,635$ & 584,000 \\
\hline Greece & 19,800 & $31.7 \%$ & 44.2 & $10,768,193$ & $4,393,900$ \\
\hline Finland & 32,100 & $44.5 \%$ & 42.5 & $5,503,297$ & $18,512,500$ \\
\hline France & 30,600 & $36.9 \%$ & 41.4 & $66,804,121$ & $2,655,500$ \\
\hline Croatia & 18,200 & $25.4 \%$ & 43.4 & $4,154,213$ & $29,375,800$ \\
\hline Hungary & 20,000 & $25.1 \%$ & 42.3 & $9,797,561$ & $1,471,600$ \\
\hline Ireland & 53,300 & $46.9 \%$ & 36.9 & $4,784,383$ & $4,131,400$ \\
\hline Italy & 28,400 & $19.3 \%$ & 45.9 & $60,589,445$ & $1,795,000$ \\
\hline Lithuania & 23,000 & $41.7 \%$ & 43.4 & $2,847,904$ & $25,864,700$ \\
\hline Luxembourg & 74,500 & $44.1 \%$ & 39.4 & 590,667 & $1,357,000$ \\
\hline Latvia & 19,600 & $33.9 \%$ & 43.1 & $1,950,116$ & 242,400 \\
\hline
\end{tabular}




\begin{tabular}{|lrlrrr|}
\hline Malta & 28,700 & $26.3 \%$ & 40.6 & 460,297 & 850,100 \\
\hline $\begin{array}{l}\text { The } \\
\text { Netherlands }\end{array}$ & 37,700 & $38.3 \%$ & 42.5 & $17,081,507$ & 183,400 \\
\hline Poland & 20,500 & $30.9 \%$ & 40.3 & $37,972,964$ & $3,100,052$ \\
\hline Portugal & 22,600 & $25.0 \%$ & 44.4 & $10,309,573$ & $14,465,800$ \\
\hline Romania & 18,400 & $17.8 \%$ & 41.8 & $19,644,350$ & $4,102,700$ \\
\hline Spain & 27,100 & $37.3 \%$ & 43.2 & $46,528,024$ & $7,482,400$ \\
\hline $\begin{array}{l}\text { Sweden } \\
\text { Slovenia }\end{array}$ & 35,600 & $43.3 \%$ & 40.8 & $9,995,153$ & $4,862,700$ \\
\hline $\begin{array}{l}\text { Slovakia } \\
\text { United }\end{array}$ & 25,100 & $32.5 \%$ & 43.5 & $2,065,895$ & 881,100 \\
\hline $\begin{array}{l}\text { Kingdom } \\
\text { EU 28 }\end{array}$ & 31,100 & $24.6 \%$ & 39.8 & $5,435,343$ & $1,874,500$ \\
\hline Norway & $\mathbf{2 9 , 5 0 0}$ & $43.2 \%$ & 40.0 & $65,844,142$ & $28,830,100$ \\
\hline
\end{tabular}

Source: author's elaboration on Eurostat data

Figure 1 and Table 2-2 summarize the food waste estimations for the European Union, both at the national and EU level, as developed on the basis of simulations run with the REFRESH Road Map (Stewart et al. 2019). 
Figure 1: estimated FW per household per week in the EU

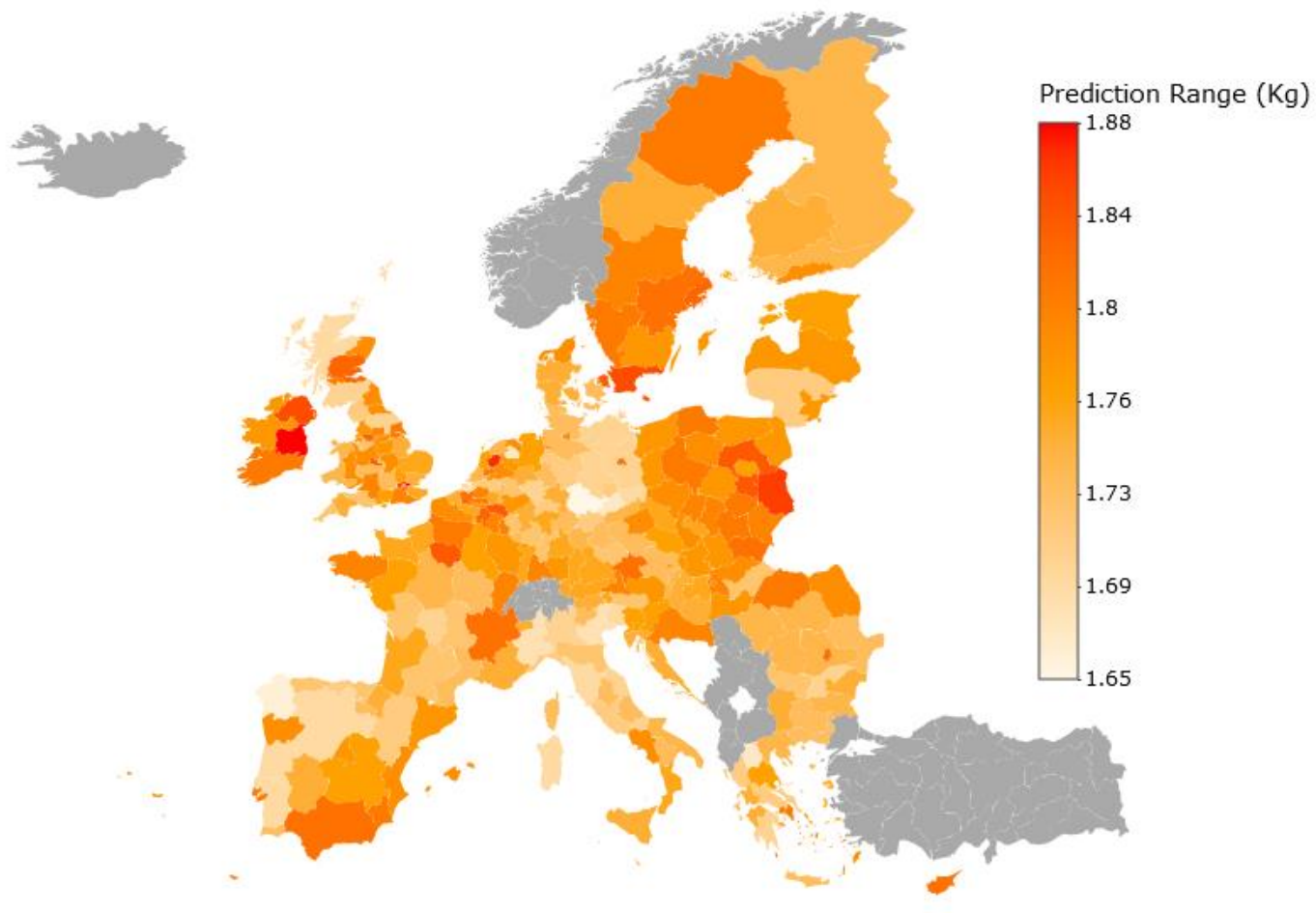

Table 2-2: EU28 -FW estimation at European level

\begin{tabular}{|llll|l|l|l|}
\hline Country & $\begin{array}{l}\text { Household } \\
\text { FW(kg/ } \\
\text { year) }\end{array}$ & $\begin{array}{l}\text { Low } \\
95 \% \\
\text { (kg/ } \\
\text { year) }\end{array}$ & $\begin{array}{l}\text { Up 95\% } \\
\text { (kg/year) }\end{array}$ & $\begin{array}{l}\text { Total } \\
\text { tons/ } \\
\text { year) }\end{array}$ & $\begin{array}{l}\text { Low } \\
\text { tons/ } \\
\text { year) }\end{array}$ & $\begin{array}{l}\text { Up } \\
\text { (tons/ } \\
\text { year) }\end{array}$ \\
\hline Ireland & 131.04 & 78.52 & 144.82 & 235,217 & 140,943 & 259,952 \\
\hline Cyprus & 131.04 & 117.52 & 145.08 & 42,090 & 37,747 & 46,600 \\
\hline Malta & 129.48 & 77.31 & 143.52 & 23,747 & 14,178 & 26,322 \\
\hline Poland & 129.48 & 77.31 & 143.00 & $1,873,032$ & $1,118,303$ & $2,068,609$ \\
\hline Slovakia & 128.96 & 77.31 & 142.74 & 241,736 & 144,911 & 267,566 \\
\hline Croatia & 127.40 & 76.27 & 141.18 & 187,482 & 112,234 & 207,760 \\
\hline Portugal & 125.84 & 75.05 & 139.36 & 516,284 & 307,921 & 571,752 \\
\hline Romania & 122.20 & 76.44 & 141.70 & 914,349 & 571,955 & $1,060,256$ \\
\hline Spain & 122.20 & 76.27 & 141.44 & $2,262,228$ & $1,411,887$ & $2,618,408$ \\
\hline Belgium & 98.54 & 56.85 & 112.32 & 469,218 & 270,719 & 534,834 \\
\hline
\end{tabular}




\begin{tabular}{|c|c|c|c|c|c|c|}
\hline Latvia & 98.28 & 56.85 & 111.80 & 83,548 & 48,331 & 95,041 \\
\hline Norway & 98.02 & 56.51 & 111.54 & 303,867 & 175,174 & 345,780 \\
\hline France & 97.76 & 56.33 & 111.80 & $2,871,778$ & $1,654,837$ & $3,284,214$ \\
\hline Lithuania & 97.76 & 56.33 & 111.28 & 132,660 & 76,444 & 151,007 \\
\hline Slovenia & 97.76 & 56.33 & 111.28 & 86,136 & 49,635 & 98,049 \\
\hline $\begin{array}{l}\text { United } \\
\text { Kingdom }\end{array}$ & 97.76 & 56.16 & 111.28 & $2,818,431$ & $1,619,098$ & $3,208,214$ \\
\hline Sweden & 97.50 & 56.16 & 111.28 & 474,113 & 273,089 & 541,121 \\
\hline Hungary & 97.24 & 56.16 & 111.02 & 401,737 & 232,019 & 458,668 \\
\hline Denmark & 96.98 & 55.81 & 110.76 & 232,354 & 133,723 & 265,370 \\
\hline Estonia & 96.72 & 55.47 & 110.76 & 56,484 & 32,393 & 64,684 \\
\hline $\begin{array}{l}\text { The } \\
\text { Netherlands }\end{array}$ & 96.72 & 55.64 & 110.24 & 756,254 & 435,049 & 861,967 \\
\hline Finland & 96.46 & 55.47 & 110.24 & 256,150 & 147,292 & 292,742 \\
\hline Greece & 96.46 & 55.47 & 110.24 & 423,836 & 243,715 & 484,384 \\
\hline Austria & 95.94 & 55.12 & 109.72 & 375,653 & 215,822 & 429,609 \\
\hline Bulgaria & 95.16 & 54.43 & 108.68 & 276,478 & 158,131 & 315,759 \\
\hline Italy & 94.64 & 54.08 & 108.16 & $2,447,835$ & $1,398,763$ & $2,797,526$ \\
\hline Deutschland & 94.12 & 53.73 & 107.64 & $3,832,811$ & $2,188,161$ & $4,383,381$ \\
\hline Luxembourg & 93.08 & 39.78 & 107.12 & 22,563 & 9,643 & 25,966 \\
\hline $\begin{array}{l}\text { Czech } \\
\text { Republic }\end{array}$ & 91.00 & 55.64 & 110.24 & 427,609 & 261,452 & 518,018 \\
\hline EU 28 & 98.02 & 56.46 & 111.71 & $21,705,610$ & $12,502,226$ & $24,735,250$ \\
\hline
\end{tabular}

Note: differences among the national values estimation and the sum of single regional values are due to computational approximations.

Source: REFRESH Road Map

The predicted food waste for the EU 28, considering the current national values for GDP per capita and higher education level amounts to about $\mathbf{2 1 , 8 5 1 , 3 5 3}$ tons per year.

At the national level, Czech Republic has the lowest estimated values of household food waste, with an average value of $91 \mathrm{~kg}$ per year, while Ireland and Cyprus shows the highest value of $\mathbf{1 3 1 . 0 4} \mathrm{kg}$ per year. 


\section{Austria}

Austria is divided in 9 regions (NUTS 2): Burgenland, Lower Austria, Vienna, Carinthia, Styria, Upper Austria, Salzburg, Tyrol, and Vorarlberg.

According to 2017 Eurostat data, the population amounts to $\mathbf{8 , 7 7 2 , 8 6 5}$ The Gross Domestic Product (GDP) per capita on purchasing power parity is $\mathbf{3 7 , 4 0 0}$ euro at the regional level, with consistent regional differences, ranging from $\mathbf{2 6 , 6 0 0}$ euro per capita in Burgenland to $\mathbf{4 4 , 5 0 0}$ euro per capita of the Salzburg region.

There are 3,915,5002 households, with an average size of. $\mathbf{2} . \mathbf{3}$ persons, and the number of households is, according to Eurostat data.

The average employment rate is $\mathbf{7 3 \%}$, while the level of tertiary education is $\mathbf{3 2 . 7 \%}$. Table 3-1 summarizes the baseline values disclosed on Eurostat data.

Table 3-1: Austria - parameters for FW estimation at regional level

\begin{tabular}{|c|c|c|c|c|c|}
\hline Region & $\begin{array}{l}\text { GDP } \\
\text { PPP } \\
\text { (EUR) }\end{array}$ & $\begin{array}{l}\text { Tertiary } \\
\text { education level }\end{array}$ & $\begin{array}{l}\text { Median } \\
\text { age }\end{array}$ & Population & $\begin{array}{l}\mathrm{N}^{\circ} \text { of } \\
\text { households }\end{array}$ \\
\hline Burgenland & 26,600 & $28.4 \%$ & 46.7 & 291,942 & 124,700 \\
\hline Lower Austria & 30,500 & $31.9 \%$ & 44.9 & $1,665,753$ & 722,300 \\
\hline Carinthia & 32,000 & $30.6 \%$ & 46.3 & 561,077 & 252,300 \\
\hline Styria & 33,900 & $28.7 \%$ & 44.5 & $1,237,298$ & 544,200 \\
\hline Upper Austria & 38,300 & $29.0 \%$ & 43.0 & $1,465,045$ & 631,900 \\
\hline Salzburg & 44,500 & $32.3 \%$ & 42.8 & 549,263 & 239,200 \\
\hline Tyrol & 40,100 & $29.9 \%$ & 42.0 & 746,153 & 325,000 \\
\hline Vorarlberg & 39,900 & $27.6 \%$ & 41.4 & 388,752 & 166,800 \\
\hline Vienna & 44,400 & $42.3 \%$ & 39.6 & $1,867,582$ & 909,200 \\
\hline Austria & 37,400 & $32.7 \%$ & 43.0 & $8,772,865$ & $3,915,500$ \\
\hline
\end{tabular}

Source: author's elaboration on Eurostat data

Figure 2 and Table 3-2 summarize the food waste estimations for the country, both at the regional and national level, as developed on the basis of simulations run with the REFRESH Road Map (Stewart et al. 2019). 
Figure 2: estimated FW per household in Austrian regions

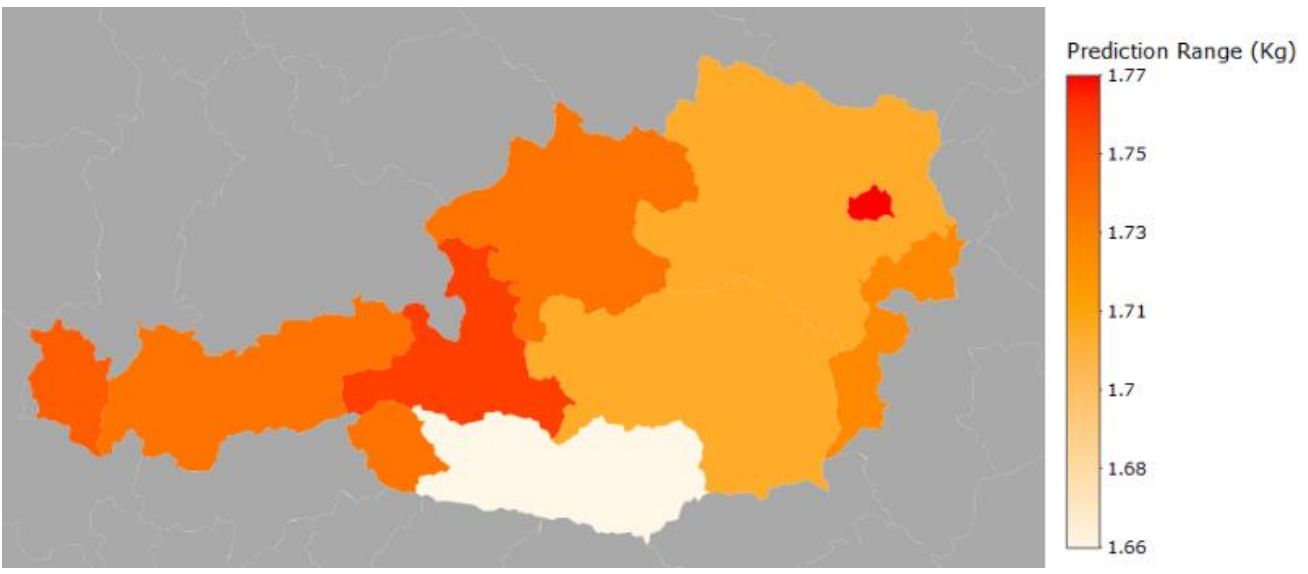

Table 3-2: Austria - FW estimation at regional level

\begin{tabular}{|c|c|c|c|c|c|c|}
\hline Region & $\begin{array}{l}\text { Household } \\
\text { FW (kg/ } \\
\text { year) }\end{array}$ & $\begin{array}{l}\text { Low } 95 \% \\
\text { (kg/ year) }\end{array}$ & $\begin{array}{l}\text { Up } 95 \% \\
\text { (kg/year) }\end{array}$ & $\begin{array}{l}\text { Total FW } \\
\text { (tons/year) }\end{array}$ & $\begin{array}{l}\text { Low } \\
95 \% \\
\text { (tons/ } \\
\text { year) }\end{array}$ & $\begin{array}{l}\text { Up 95\% } \\
\text { (tons/ } \\
\text { year) }\end{array}$ \\
\hline Vienna & 99.84 & 57.72 & 113.36 & 90,538 & 52,321 & 103,067 \\
\hline Upper Austria & 98.28 & 56.68 & 111.8 & 62,103 & 35,926 & 70,646 \\
\hline Salzburg & 97.76 & 56.68 & 111.28 & 23,384 & 13,516 & 26,618 \\
\hline Vorarlberg & 97.76 & 56.68 & 111.28 & 16,306 & 9,454 & 18,562 \\
\hline Carinthia & 96.72 & 55.64 & 109.72 & 24,337 & 14,082 & 27,682 \\
\hline Lower Austria & 96.20 & 55.64 & 109.72 & 69,485 & 40,064 & 79,251 \\
\hline Tyrol & 96.20 & 55.64 & 109.72 & 31,265 & 18,027 & 35,659 \\
\hline Burgenland & 96.20 & 55.64 & 109.72 & 11,996 & 6,917 & 13,682 \\
\hline Styria & 94.64 & 54.08 & 108.16 & 51,503 & 29,525 & 58,861 \\
\hline Austria & 95.94 & 55.12 & 109.72 & 306,197 & 175,918 & 350,177 \\
\hline
\end{tabular}

Note: differences among the national values estimation and the sum of single regional values are due to computational approximations.

Source: REFRESH Road Map

The predicted food waste for Austria, considering the actual regional values for GDP per capita and higher education level amounts to $95.94 \mathrm{~kg}$ per household and an overall total of almost $\mathbf{3 8 2 , 5 7 7}$ tons per year.

At the regional level the lowest estimated values of food waste are registered in the Styria, with an average household FW of $\mathbf{9 4 . 6 4} \mathbf{k g}$ per year, while the highest are recorded in the Vienna region, with a value of $\mathbf{9 9 . 8 4} \mathbf{k g}$ per year. 


\section{Belgium}

Belgium is divided in 9 regions (NUTS 2): Brussels, Antwerp, Limburg, East Flanders, Flemish Brabant, West Flanders, Walloon Brabant, Hainaut, Liège, Luxembourg, and Namur.

According to 2017 Eurostat data, the population amounts to $\mathbf{1 1 , 3 5 1 , 7 2 7}$. The Gross Domestic Product (GDP) per capita on purchasing power parity is $\mathbf{3 4 , 3 0 0}$ euro at the regional level, with consistent regional differences, ranging from $\mathbf{2 1 , 6 0 0}$ euro per capita in Luxembourg area to $\mathbf{5 7 , 7 0 0}$ euro per capita of the Brussels region.

There are 4,761,700 households, with an average size of $\mathbf{2 . 3}$ persons.

The average employment rate is $\mathbf{6 1 . 1 \%}$, while the level of tertiary education is $\mathbf{4 0 . 6 \%}$. Table 4-1 summarizes the baseline values disclosed on Eurostat data.

Table 4-1: Belgium - parameters for FW estimation at regional level

\begin{tabular}{|c|c|c|c|c|c|}
\hline Region & $\begin{array}{l}\text { GDP } \\
\text { PPP } \\
\text { (EUR) }\end{array}$ & $\begin{array}{l}\text { Tertiary } \\
\text { education level }\end{array}$ & $\begin{array}{l}\text { Median } \\
\text { age }\end{array}$ & Population & $\begin{array}{l}\text { No of } \\
\text { households }\end{array}$ \\
\hline Brussels & 57,700 & $40.6 \%$ & 41.5 & $1,199,095$ & 533,700 \\
\hline Antwerp & 41,300 & $47.5 \%$ & 35.7 & $1,838,863$ & 760,000 \\
\hline Limburg & 28,400 & $40.0 \%$ & 42.0 & 869,664 & 349,500 \\
\hline East Flanders & 31,800 & $35.8 \%$ & 43.9 & $1,498,483$ & 632,600 \\
\hline $\begin{array}{l}\text { Flemish } \\
\text { Brabant }\end{array}$ & 36,800 & $42.8 \%$ & 42.5 & $1,130,644$ & 451,200 \\
\hline West Flanders & 33,800 & $48.7 \%$ & 42.5 & $1,188,407$ & 501,600 \\
\hline $\begin{array}{l}\text { Walloon } \\
\text { Brabant }\end{array}$ & 38,800 & $37.3 \%$ & 45.6 & 399,735 & 155,300 \\
\hline Hainaut & 22,000 & $58.4 \%$ & 41.8 & $1,342,053$ & 571,300 \\
\hline Liège & 24,800 & $31.4 \%$ & 41.5 & $1,106,039$ & 476,300 \\
\hline Luxembourg & 21,600 & $35.9 \%$ & 41.2 & 284,617 & 113,200 \\
\hline Namur & 23,400 & $38.8 \%$ & 39.5 & 494,127 & 217,100 \\
\hline Belgium & 34,300 & $40.6 \%$ & 41.5 & $11,351,727$ & $4,761,700$ \\
\hline
\end{tabular}

Source: author's elaboration on Eurostat data 


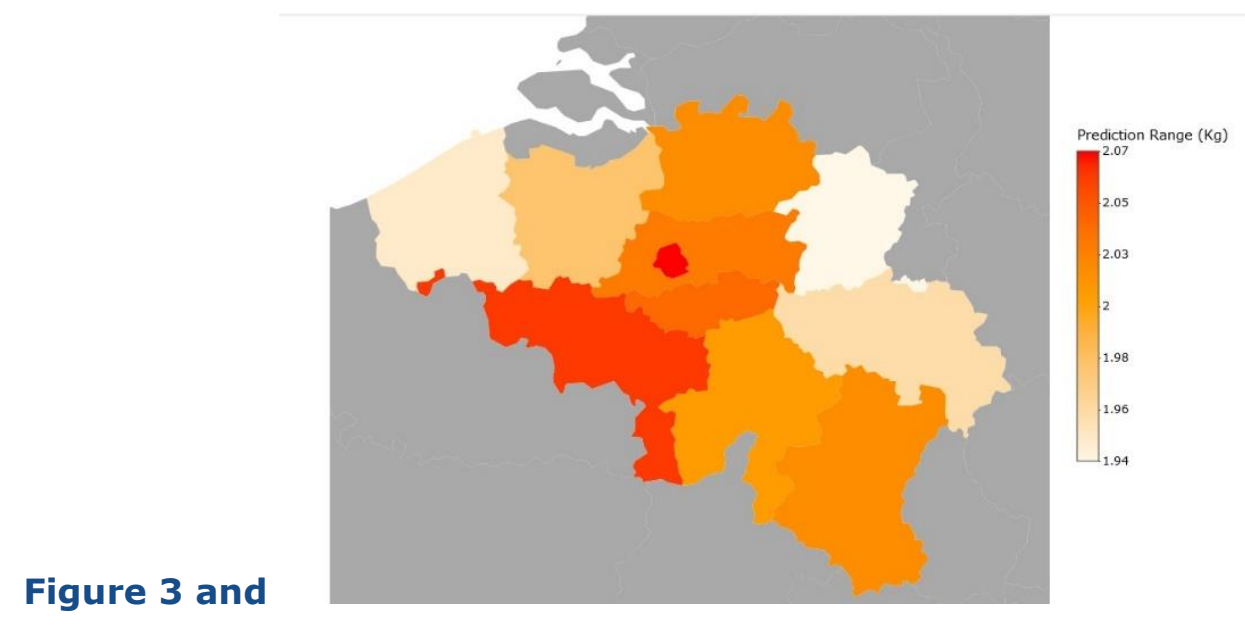

Table 4-2 summarize the food waste estimations for the country, both at the regional and national level, as developed by on basis of simulations run with the REFRESH Road Map (Stewart et al, 2019).

Figure 3: estimated FW per household in Belgian regions

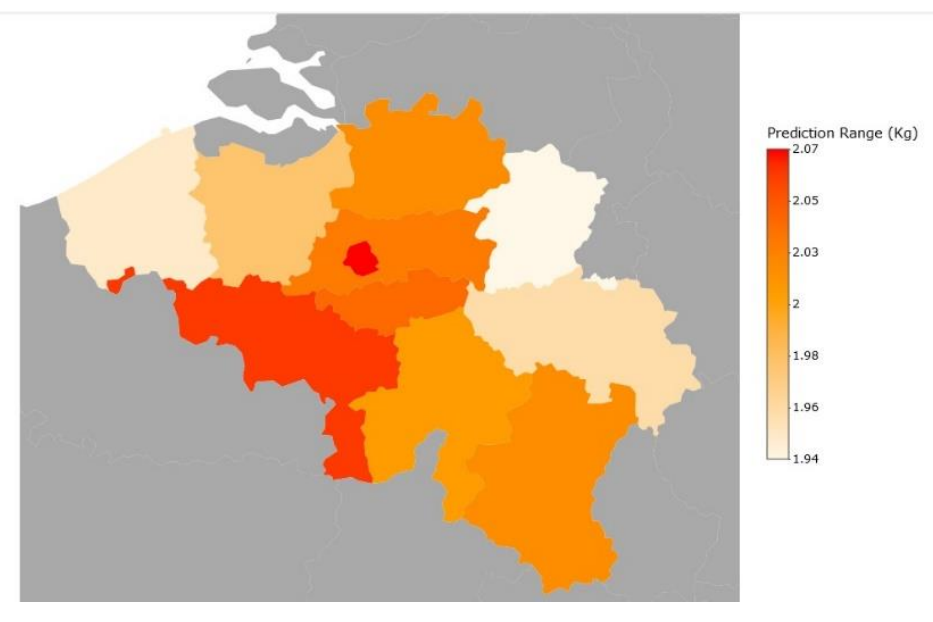

Table 4-2: Belgium - FW estimation at regional level

\begin{tabular}{lrrrr|rrr|}
\hline Region & $\begin{array}{l}\text { Household } \\
\text { FW (kg/ } \\
\text { year) }\end{array}$ & $\begin{array}{l}\text { Low 95\% } \\
\text { (kg/ year) }\end{array}$ & $\begin{array}{l}\text { Up 95\% } \\
\text { (kg/year) }\end{array}$ & $\begin{array}{l}\text { Total } \\
\text { (tons/year) }\end{array}$ & $\begin{array}{l}\text { Low } \\
95 \% \\
\text { (tons/ } \\
\text { year) }\end{array}$ & $\begin{array}{l}\text { Up } 95 \% \\
\text { (tons/ } \\
\text { year) }\end{array}$ \\
\hline Brussels & 103.48 & 59.97 & 117.52 & 55,227 & 32,008 & 62,720 \\
\hline $\begin{array}{l}\text { Walloon } \\
\text { Brabant }\end{array}$ & 101.66 & 59.28 & 114.92 & 15,788 & 9,206 & 17,847 \\
\hline Luxembourg & 101.40 & 58.59 & 115.44 & 11,478 & 6,632 & 13,068 \\
\hline Liège & 99.32 & 57.55 & 112.84 & 47,306 & 27,409 & 53,746 \\
\hline Namur & 99.32 & 57.55 & 112.84 & 21,562 & 12,493 & 24,498 \\
\hline
\end{tabular}




\begin{tabular}{lrrr|rrr|}
\hline Hainaut & 98.80 & 57.03 & 112.32 & 56,444 & 32,579 & 64,168 \\
\hline Antwerp & 98.28 & 57.03 & 111.8 & 74,693 & 43,340 & 84,968 \\
\hline Limburg & 98.28 & 56.68 & 111.8 & 34,349 & 19,810 & 39,074 \\
\hline $\begin{array}{l}\text { Flemish } \\
\text { Brabant }\end{array}$ & 97.76 & 56.51 & 110.76 & 44,109 & 25,496 & 49,975 \\
\hline East Flanders & 96.46 & 55.81 & 109.72 & 61,021 & 35,308 & 69,409 \\
\hline West Flanders & 93.08 & 53.39 & 106.6 & 46,689 & 26,779 & 53,471 \\
\hline Belgium & 98.54 & 56.85 & 112.32 & 469,218 & 270,719 & 534,834 \\
\hline
\end{tabular}

Note: differences among the national values estimation and the sum of single regional values are due to computational approximations,

Source: REFRESH Road Map

The predicted food waste for Belgium, considering the actual regional values for GDP per capita and higher education level amounts to $\mathbf{9 8 . 5 4} \mathrm{kg}$ per household and an overall total of almost $\mathbf{4 6 9 , 2 1 8}$ tons per year, At the regional level the lowest estimated values of food waste are registered in West Flanders, with an average household FW of $93.08 \mathrm{~kg}$ per year, while the highest are recorded in Brussels, with a value of $\mathbf{1 0 3 . 4 8} \mathrm{kg}$ per year. 


\section{Bulgaria}

Bulgaria is divided in 6 regions (NUTS 2): Severozapaden, Severen tsentralen, Severoiztochen, Yugoiztochen, Yugozapaden, and Yuzhen tsentralen.

According to 2017 Eurostat data, the population amounts to $\mathbf{7 , 1 0 1 , 8 5 9}$. The Gross Domestic Product (GDP) per capita on purchasing power parity is $\mathbf{1 4 , 5 0 0}$ euro at the regional level, with consistent regional differences, ranging from 9,100 euro per capita of Severozapaden area to $\mathbf{2 3 , 3 0 0}$ euro per capita of the Yugozapaden region.

There are $\mathbf{2 , 9 0 5 , 4 0 0}$ households, with an average size of $\mathbf{2 . 3}$ persons.

The average employment rate is $\mathbf{6 6 . 9 \%}$, while the level of tertiary education is $\mathbf{2 8 . 2} \%$. Table 5-1 summarizes the baseline values disclosed on Eurostat data.

Table 5-1: Bulgaria - parameters for FW estimation at regional level

\begin{tabular}{|c|c|c|c|c|c|}
\hline Region & $\begin{array}{l}\text { GDP } \\
\text { PPP } \\
\text { (EUR) }\end{array}$ & $\begin{array}{l}\text { Tertiary } \\
\text { education } \\
\text { level }\end{array}$ & $\begin{array}{l}\text { Median } \\
\text { age }\end{array}$ & Population & $\begin{array}{l}N^{\circ} \text { of } \\
\text { households }\end{array}$ \\
\hline Severozapaden & 57,700 & $40.6 \%$ & 41.5 & $1,199,095$ & 533,700 \\
\hline $\begin{array}{l}\text { Severen } \\
\text { tsentralen }\end{array}$ & 41,300 & $47.5 \%$ & 35.7 & $1,838,863$ & 760,000 \\
\hline Severoiztochen & 28,400 & $40.0 \%$ & 42.0 & 869,664 & 349,500 \\
\hline Yugoiztochen & 31,800 & $35.8 \%$ & 43.9 & $1,498,483$ & 632,600 \\
\hline Yugozapaden & 36,800 & $42.8 \%$ & 42.5 & $1,130,644$ & 451,200 \\
\hline $\begin{array}{l}\text { Yuzhen } \\
\text { tsentralen }\end{array}$ & 33,800 & $48.7 \%$ & 42.5 & $1,188,407$ & 501,600 \\
\hline Bulgaria & 14,500 & $28.2 \%$ & 43.9 & $7,101,859$ & $2,905,400$ \\
\hline
\end{tabular}

Source: author's elaboration on Eurostat data

Figure 4 and
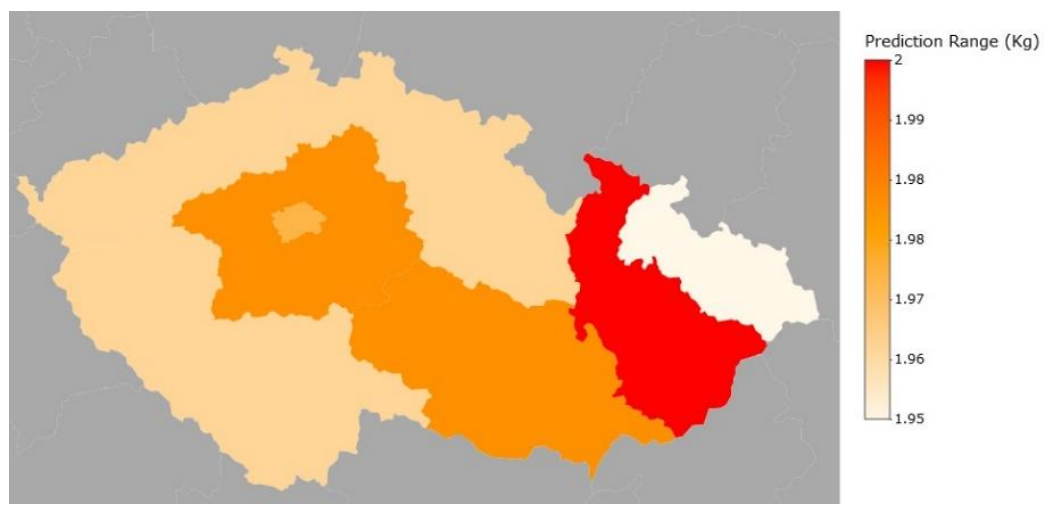

Table 7-2 summarize the food waste estimations for the country, both at the regional and national level, as developed by on basis of simulations run with the REFRESH Road Map (Stewart et al, 2019). 
Figure 4: estimated FW per household in Bulgarian regions

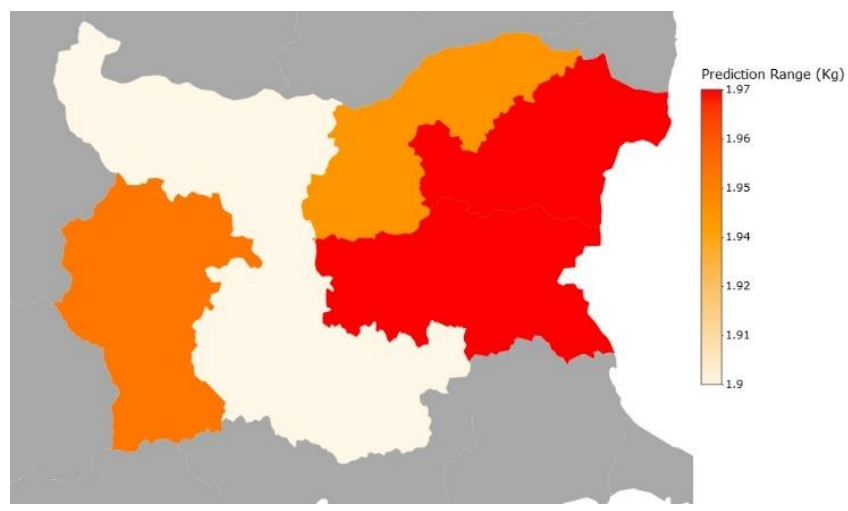

Table 5-2: Bulgaria - FW estimation at regional level

\begin{tabular}{|c|c|c|c|c|c|c|}
\hline Region & $\begin{array}{l}\text { Household } \\
\text { FW (kg/ } \\
\text { year) }\end{array}$ & $\begin{array}{l}\text { Low 95\% } \\
\text { (kg/ } \\
\text { year) }\end{array}$ & $\begin{array}{l}\text { Up } 95 \% \\
\text { (kg/year) }\end{array}$ & $\begin{array}{l}\text { Total FW } \\
\text { (tons/year) }\end{array}$ & $\begin{array}{l}\text { Low } \\
95 \% \\
\text { (tons/ } \\
\text { year) }\end{array}$ & $\begin{array}{l}\text { Up } 95 \% \\
\text { (tons/ } \\
\text { year) }\end{array}$ \\
\hline Severoiztochen & 96.72 & 55.47 & 109.98 & 36,995 & 21,216 & 42,067 \\
\hline Yugoiztochen & 96.72 & 55.47 & 110.76 & 42,615 & 24,439 & 48,801 \\
\hline Yugozapaden & 96.20 & 55.12 & 109.72 & 84,618 & 48,484 & 96,510 \\
\hline $\begin{array}{l}\text { Severen } \\
\text { Tsentralen }\end{array}$ & 94.64 & 54.43 & 108.42 & 31,155 & 17,917 & 35,692 \\
\hline $\begin{array}{l}\text { Yuzhen } \\
\text { Tsentralen }\end{array}$ & 92.82 & 53.04 & 106.6 & 51,738 & 29,564 & 59,419 \\
\hline Severozapaden & 92.56 & 52.87 & 106.6 & 29,249 & 16,706 & 33,686 \\
\hline Bulgaria & 95.16 & 54.43 & 108.68 & 276,478 & 158,131 & 315,759 \\
\hline
\end{tabular}

Note: differences among the national values estimation and the sum of single regional values are due to computational approximations.

Source: REFRESH Road Map

The predicted food waste for Bulgaria, considering the actual regional values for GDP per capita and higher education level amounts to $95.16 \mathrm{~kg}$ per household and an overall total of almost $\mathbf{2 7 6 , 4 7 8}$ tons per year.

At the regional level the lowest estimated values of food waste are registered in Severozapaden, with an average household FW of $\mathbf{9 2 . 5 6} \mathbf{k g}$ per year, while the highest are recorded in Severoiztochen, with a value of $\mathbf{9 6 . 7 2} \mathbf{k g}$ per year. 


\section{Croatia}

Croatia is divided in 2 regions (NUTS 2): Jadranska Hrvatska, and Kontinentalna Hrvatska.

According to 2017 Eurostat data, the population amounts to $\mathbf{4 , 2 5 4 , 3 1 3 . ~ T h e ~ G r o s s ~}$ Domestic Product (GDP) per capita on purchasing power parity is 18,200 euro, $\mathbf{1 7 , 5 0 0}$ euro per capita in Jadranska Hrvatska area and 18,200 euro per capita in the Kontinentalna Hrvatska region.

There are $\mathbf{2 , 6 5 5 , 5 0 0}$ households, with an average size of $\mathbf{2 . 8}$ persons.

The average employment rate is $\mathbf{5 8 . 9} \%$, while the level of tertiary education is $\mathbf{2 5 . 4 \%}$. Table 6-1 summarizes the baseline values disclosed on Eurostat data.

Table 6-1: Croatia - parameters for FW estimation at regional level

\begin{tabular}{lrrrrr} 
Region & $\begin{array}{l}\text { GDP } \\
\text { PPP } \\
\text { (EUR) }\end{array}$ & $\begin{array}{l}\text { Tertiary } \\
\text { education level }\end{array}$ & $\begin{array}{l}\text { Median } \\
\text { age }\end{array}$ & Population & $\begin{array}{l}\mathrm{N}^{\circ} \text { of } \\
\text { households }\end{array}$ \\
$\begin{array}{l}\text { Jadranska } \\
\text { Hrvatska }\end{array}$ & 17,500 & $26.6 \%$ & 44.4 & $1,387,363$ & 502,200 \\
$\begin{array}{l}\text { Kontinentalna } \\
\text { Hrvatska }\end{array}$ & 18,600 & $24.8 \%$ & 42.9 & $2,766,850$ & 969,300 \\
\hline Croatia & 18,200 & $25.4 \%$ & 43.4 & $4,154,213$ & $1,471,600$
\end{tabular}

Source: author's elaboration on Eurostat data

Figure 5 and Table 6-2 summarize the food waste estimations for the country, both at the regional and national level, as developed by on basis of simulations run with the REFRESH Road Map (Stewart et al, 2019).

Figure 5: estimated FW per household in Croatian regions

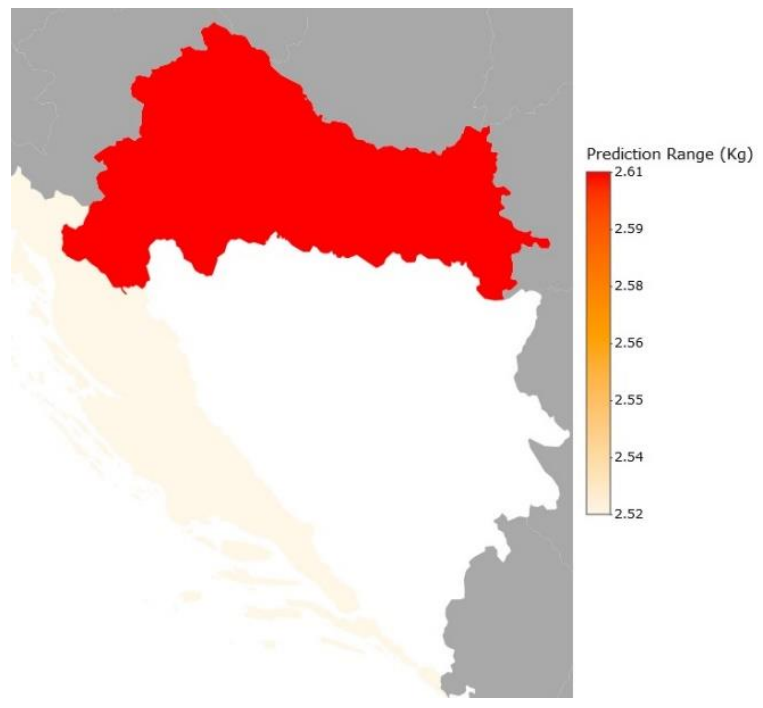


Table 6-2: Croatia - FW estimation at regional level

\begin{tabular}{lrlr|rrr|} 
Region & $\begin{array}{l}\text { Household } \\
\text { FW (kg/ } \\
\text { year) }\end{array}$ & $\begin{array}{l}\text { Low } \\
95 \% \\
\text { (kg/ } \\
\text { year) }\end{array}$ & $\begin{array}{l}\text { Up 95\% } \\
\text { (kg/year) }\end{array}$ & $\begin{array}{l}\text { Total FW } \\
\text { (tons/year) }\end{array}$ & $\begin{array}{l}\text { Low } \\
95 \% \\
\text { (tons/ } \\
\text { year) }\end{array}$ & $\begin{array}{l}\text { Up 95\% } \\
\text { (tons/ } \\
\text { year) }\end{array}$ \\
\hline $\begin{array}{l}\text { Jadranska } \\
\text { Hrvatska }\end{array}$ & 132.08 & 79.04 & 145.6 & 66,331 & 39,694 & 73,120 \\
$\begin{array}{l}\text { Kontinentalna } \\
\text { Hrvatska }\end{array}$ & 127.40 & 76.27 & 141.18 & 123,489 & 73,925 & 136,846 \\
\hline Croatia & 127.40 & 76.27 & 141.18 & 187,482 & 112,234 & 207,760 \\
\hline
\end{tabular}

Note: differences among the national values estimation and the sum of single regional values are due to computational approximations.

Source: REFRESH Road Map

The predicted food waste for Croatia. Considering the actual regional values for GDP per capita and higher education level amounts to $\mathbf{1 2 7 . 4} \mathrm{kg}$ per household and an overall total of almost $\mathbf{1 8 7 , 4 8 2}$ tons per year.

At the regional level, the lowest estimated values of food waste are registered in Kontinentalna Hrvatska with an average household FW of $\mathbf{1 2 7 . 4} \mathrm{kg}$ per year, while the highest are recorded in Jadranska Hrvatska with a value of $\mathbf{1 3 2 . 8} \mathrm{kg}$ per year. 


\section{Czech Republic}

Czech Republic is divided in 8 regions (NUTS 2): Prague, Střední Čechy, Jihozápad, Severozápad, Severovýchod, Jihovýchod, Střední Morava, andMoravskoslezsko.

According to 2017 Eurostat data, the population amounts to $\mathbf{1 0 , 5 7 8 , 8 2 0}$, The Gross Domestic Product (GDP) per capita on purchasing power parity is $\mathbf{2 6 , 4 0 0}$ euro, with some regional differences ranging from 18,700 euro per capita of Severozápad area to the 55,200 euro per capita of the Prague region.

There are 4,699,000 households, with an average size of $\mathbf{2 . 3}$ persons.

The average employment rate is $\mathbf{7 3 . 6 \%}$, while the level of tertiary education is $\mathbf{2 4 . 3 \%}$. Table 7-1 summarizes the baseline values disclosed on Eurostat data.

Table 7-1: Czech Republic - parameters for FW estimation at regional level

\begin{tabular}{|c|c|c|c|c|c|}
\hline Region & $\begin{array}{l}\text { GDP } \\
\text { PPP } \\
\text { (EUR) }\end{array}$ & $\begin{array}{l}\text { Tertiary } \\
\text { education } \\
\text { level }\end{array}$ & $\begin{array}{l}\text { Median } \\
\text { age }\end{array}$ & Population & $\begin{array}{l}N^{\circ} \text { of } \\
\text { households }\end{array}$ \\
\hline Prague & 55,200 & $46.4 \%$ & 41.1 & $1,280,508$ & 652,900 \\
\hline Střední Čechy & 24,700 & $23.6 \%$ & 41.1 & $1,338,982$ & 583,600 \\
\hline Jihozápad & 22,800 & $20.1 \%$ & 42.4 & $1,217,411$ & 526,100 \\
\hline Severozápad & 18,700 & $13.9 \%$ & 42.1 & $1,118,126$ & 526,800 \\
\hline Severovýchod & 22,200 & $20.6 \%$ & 42.2 & $1,508,527$ & 641,600 \\
\hline Jihovýchod & 23,900 & $25.8 \%$ & 42.0 & $1,687,764$ & 684,200 \\
\hline Střední Morava & 21,600 & $19.5 \%$ & 42.5 & $1,217,623$ & 532,600 \\
\hline Moravskoslezsko & 21,700 & $21.1 \%$ & 42.4 & $1,209,879$ & 551,200 \\
\hline Czech Republic & 26,400 & $24.3 \%$ & 41.9 & $10,578,820$ & $4,699,000$ \\
\hline
\end{tabular}

Source: author's elaboration on Eurostat data

Figure 6 and

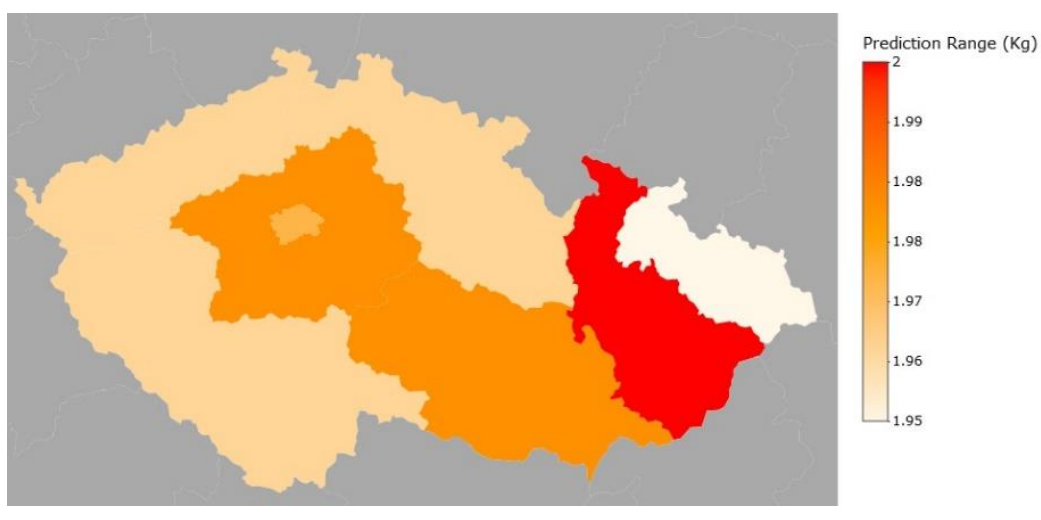

Table 7-2 summarize the food waste estimations for the country, both at the regional and national level, as developed by on basis of simulations run with the REFRESH Road Map (Stewart et al, 2019). 
Figure 6: estimated FW per household in Czech regions

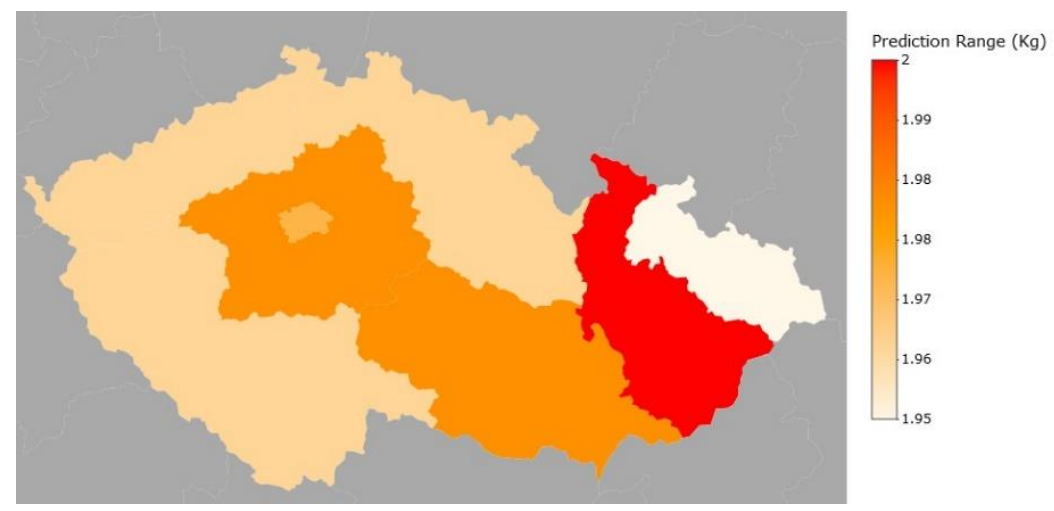

Table 7-2: Czech Republic - FW estimation at regional level

\begin{tabular}{|c|c|c|c|c|c|c|}
\hline Region & $\begin{array}{l}\text { Household } \\
\text { FW ( } \mathrm{kg} / \\
\text { year) }\end{array}$ & $\begin{array}{l}\text { Low } \\
95 \% \\
\text { (kg/ } \\
\text { year) }\end{array}$ & $\begin{array}{l}\text { Up } 95 \% \\
\text { (kg/year) }\end{array}$ & $\begin{array}{l}\text { Total FW } \\
\text { (tons/year) }\end{array}$ & $\begin{array}{l}\text { Low } \\
95 \% \\
\text { (tons/ } \\
\text { year) }\end{array}$ & $\begin{array}{l}\text { Up 95\% } \\
\text { (tons/ } \\
\text { year) }\end{array}$ \\
\hline Střední Morava & 92.56 & 56.68 & 112.32 & 49,297 & 30,188 & 59,822 \\
\hline Střední Čechy & 91.52 & 55.99 & 111.02 & 53,411 & 32,674 & 64,791 \\
\hline Prague & 91.52 & 56.16 & 111.02 & 59,753 & 36,667 & 72,485 \\
\hline Jihovýchod & 91.52 & 55.81 & 111.02 & 62,618 & 38,187 & 75,960 \\
\hline Jihozápad & 90.48 & 55.29 & 109.72 & 47,602 & 29,090 & 57,724 \\
\hline Severovýchod & 90.48 & 55.29 & 109.72 & 58,052 & 35,476 & 70,396 \\
\hline Severozápad & 89.96 & 54.77 & 109.2 & 47,391 & 28,855 & 57,527 \\
\hline Moravskoslezsko & 89.96 & 55.12 & 109.2 & 49,586 & 30,382 & 60,191 \\
\hline Czech Republic & 91.00 & 55.64 & 110.24 & 427,609 & 261,452 & 518,018 \\
\hline
\end{tabular}

Note: differences among the national values estimation and the sum of single regional values are due to computational approximations.

Source: REFRESH Road Map

The predicted food waste for Czech Republic, considering the actual regional values for GDP per capita and higher education level amounts to $91 \mathrm{~kg}$ per household and an overall total of almost 427,609 tons per year.

At the regional level, the lowest estimated values of food waste are registered in Moravskoslezsko, with an average household FW of $\mathbf{8 9 . 9 6} \mathbf{k g}$ per year, while the highest are recorded in Střední Morava, with a value of $\mathbf{9 2 . 5 6} \mathbf{k g}$ per year. 


\section{Cyprus}

The whole Cyprus territory is considered as a unique NUTS 2 Region.

According to 2017 Eurostat data, the population amounts to $\mathbf{8 5 4 , 8 0 2}$. The Gross Domestic Product (GDP) per capita on purchasing power parity is 25,000 euro.

There are $\mathbf{3 2 1 , 2 0 0}$ households with an average size of $\mathbf{2 . 3}$ persons.

The average employment rate is $\mathbf{6 5 . 6 \%}$, while the level of tertiary education is $\mathbf{4 4 . 1} \%$. Table 8-1 summarizes the baseline values disclosed on Eurostat data.

Table 8-1: Cyprus - parameters for FW estimation at regional level

$\begin{array}{lllrrr}\text { Region } & \begin{array}{l}\text { GDP } \\ \text { PPP } \\ \text { (EUR) }\end{array} & \begin{array}{l}\text { Tertiary } \\ \text { education } \\ \text { level }\end{array} & \begin{array}{l}\text { Median } \\ \text { age }\end{array} & \text { Population } & \begin{array}{l}N^{\circ} \text { of } \\ \text { households }\end{array} \\ \text { Cyprus } & 25,000 & 44.1 \% & 37.4 & 854,802 & 321,200\end{array}$

Source: author's elaboration on Eurostat data

Table 8-2 summarizes the food waste estimations for the country as developed by on basis of simulations run with the REFRESH Road Map (Stewart et al, 2019).

Table 8-2: Cyprus - FW estimation at regional level

\begin{tabular}{llrr|rrr|} 
Region & $\begin{array}{l}\text { Household } \\
\text { FW }(\mathrm{kg} / \\
\text { year) }\end{array}$ & $\begin{array}{l}\text { Low 95\% } \\
\text { (kg/ year) }\end{array}$ & $\begin{array}{l}\text { Up 95\% } \\
\text { (kg/year) }\end{array}$ & $\begin{array}{l}\text { Total FW } \\
\text { (tons/year) }\end{array}$ & $\begin{array}{l}\text { Low } \\
95 \% \\
\text { (tons/ } \\
\text { year) }\end{array}$ & $\begin{array}{l}\text { Up 95\% } \\
\text { (tons/ } \\
\text { year) }\end{array}$ \\
Cyprus & 131.04 & 117.52 & 145.08 & 42,090 & 37,747 & 46,600
\end{tabular}

Note: differences among the national values estimation and the sum of single regional values are due to computational approximations.

Source: REFRESH Road Map

The predicted food waste for Cyprus, considering the actual regional values for GDP per capita and higher education level amounts to $\mathbf{1 3 1 . 0 4} \mathrm{kg}$ per household and an overall total of almost $\mathbf{4 2 , 0 9 0}$ tons per year. 


\section{Denmark}

Denmark is divided in 5 regions (NUTS 2): Hovedstaden, Sjælland, Southern Denmark, Midtjylland, and Nordjylland.

According to 2017 Eurostat data, the population amounts to $\mathbf{5 , 7 4 8 , 7 6 9}$. The Gross Domestic Product (GDP) per capita on purchasing power parity is $\mathbf{3 7 , 7 0 0}$ euro, with some regional differences ranging from $\mathbf{2 5 , 8 0 0}$ euro per capita of Sjælland area to the 48,900 euro per capita of the Hovedstaden region.

There are 2,395,900 households, with an average size of $\mathbf{2}$ persons.

The average employment rate is $\mathbf{7 4 . 2} \%$, while the level of tertiary education is $\mathbf{3 9 . 7 \%}$. Table 9-1 summarizes the baseline values disclosed on Eurostat data.

Table 9-1: Denmark - parameters for FW estimation at regional level

\begin{tabular}{llrrrr} 
Region & $\begin{array}{l}\text { GDP } \\
\text { PPP } \\
\text { (EUR) }\end{array}$ & \multicolumn{1}{l}{$\begin{array}{l}\text { Tertiary } \\
\text { education } \\
\text { level }\end{array}$} & $\begin{array}{l}\text { Median } \\
\text { age }\end{array}$ & Population & \multicolumn{2}{l}{$\begin{array}{l}N^{\circ} \text { of } \\
\text { households }\end{array}$} \\
\hline Hovedstaden & 48,900 & $51.5 \%$ & 38.8 & $1,807,404$ & 714,300 \\
\hline Sjælland & 25,800 & $31.2 \%$ & 45.4 & 832,553 & 332,900 \\
\hline $\begin{array}{l}\text { Southern } \\
\text { Denmark }\end{array}$ & 33,600 & $32.7 \%$ & 43.5 & $1,217,224$ & 531,800 \\
\hline Midtjylland & 33,800 & $37.8 \%$ & 40.8 & $1,304,253$ & 579,800 \\
\hline Nordjylland & 32,200 & $32.2 \%$ & 43.2 & 587,335 & 237,000 \\
\hline Denmark & 37,700 & $39.7 \%$ & 41.6 & $5,748,769$ & $2,395,900$ \\
\hline
\end{tabular}

Source: author's elaboration on Eurostat data

Figure 7 and

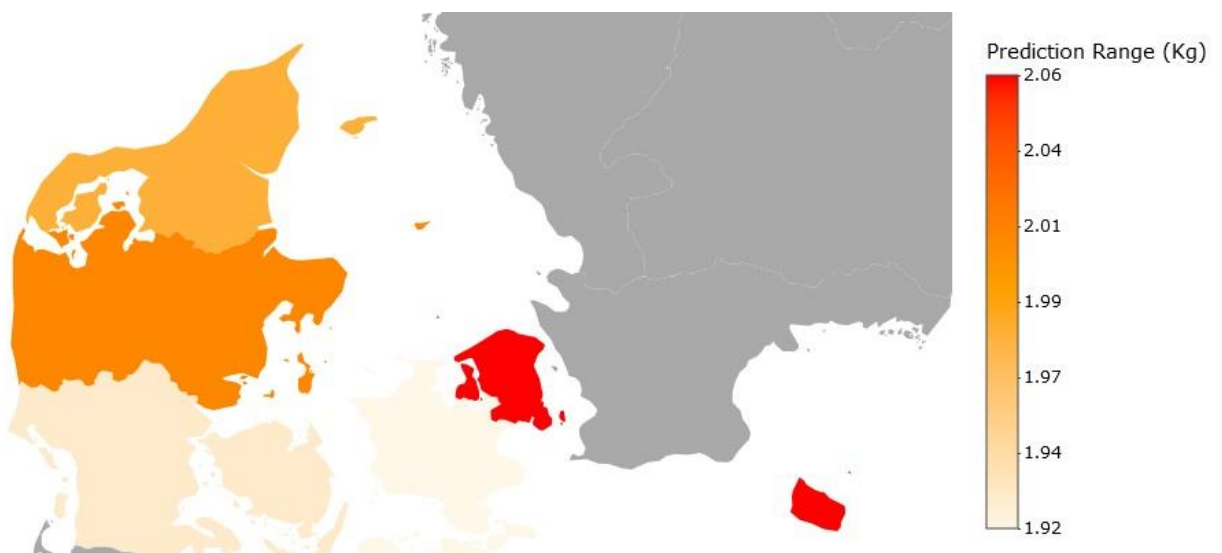

Table 9-2 summarize the food waste estimations for the country, both at the regional and national level, as developed by on basis of simulations run with the REFRESH Road Map (Stewart et al, 2019). 
Figure 7: estimated FW per household in Danish regions

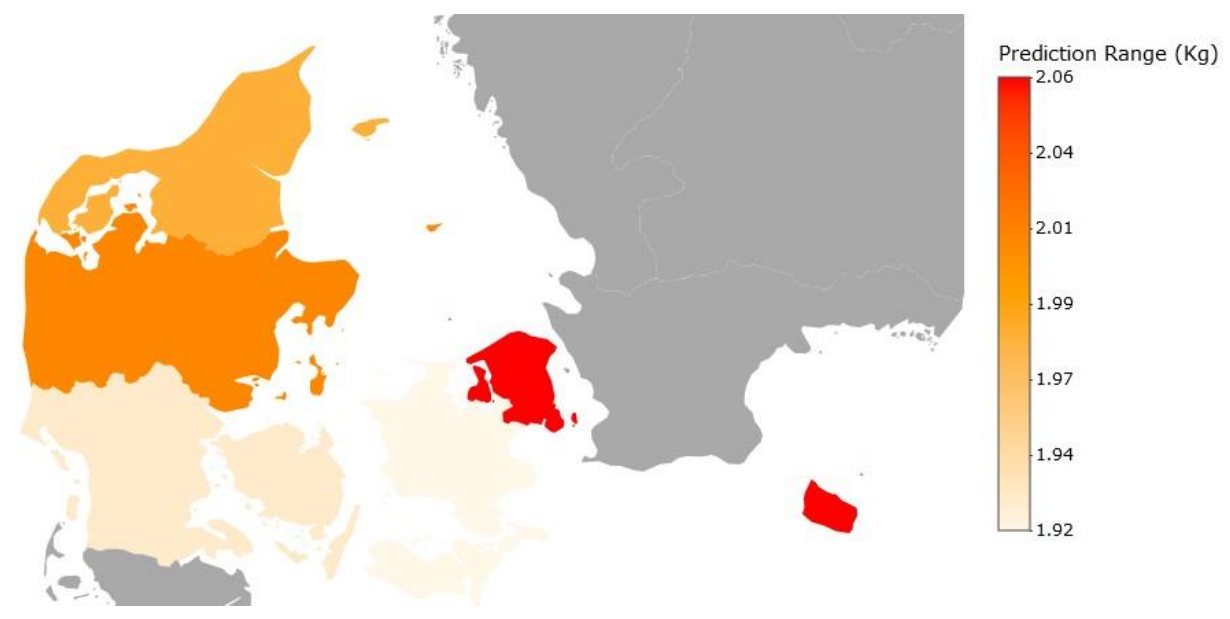

Table 9-2: Denmark - FW estimation at regional level

\begin{tabular}{|c|c|c|c|c|c|c|}
\hline Region & $\begin{array}{l}\text { Household } \\
\text { FW (kg/ } \\
\text { year) }\end{array}$ & $\begin{array}{l}\text { Low } 95 \% \\
\text { (kg/ year) }\end{array}$ & $\begin{array}{l}\text { Up } 95 \% \\
\text { (kg/year) }\end{array}$ & $\begin{array}{l}\text { Total FW } \\
\text { (tons/year) }\end{array}$ & $\begin{array}{l}\text { Low } \\
95 \% \\
\text { (tons/ } \\
\text { year) }\end{array}$ & $\begin{array}{l}\text { Up 95\% } \\
\text { (tons/ } \\
\text { year) }\end{array}$ \\
\hline Hovedstaden & 101.92 & 58.93 & 115.44 & 72,801 & 42,096 & 82,459 \\
\hline Midtjylland & 98.80 & 56.85 & 112.32 & 57,284 & 32,964 & 65,123 \\
\hline Nordjylland & 96.72 & 55.47 & 110.24 & 22,923 & 13,146 & 26,127 \\
\hline $\begin{array}{l}\text { Southern } \\
\text { Denmark }\end{array}$ & 94.12 & 53.91 & 107.64 & 50,053 & 28,668 & 57,243 \\
\hline Sjælland & 93.60 & 53.39 & 107.64 & 31,159 & 17,772 & 35,833 \\
\hline Denmark & 96.98 & 55.81 & 110.76 & 232,354 & 133,723 & 265,370 \\
\hline
\end{tabular}

Note: differences among the national values estimation and the sum of single regional values are due to computational approximations.

Source: REFRESH Road Map

The predicted food waste for Denmark, considering the actual regional values for GDP per capita and higher education level amounts to $\mathbf{9 6 . 9 8} \mathbf{k g}$ per household and an overall total of almost $\mathbf{2 3 2 , 2 5 4}$ tons per year.

At the regional level the lowest estimated values of food waste are registered in Sjælland, with an average household FW of $\mathbf{9 3 . 6 0} \mathrm{kg}$ per year, while the highest are recorded in Hovedstaden, with a value of $\mathbf{1 0 1 . 9 2} \mathrm{kg}$ per year. 


\section{Estonia}

The whole Estonia territory is considered as a unique NUTS 2 Region.

According to 2017 Eurostat data, the population amounts to $\mathbf{1 , 3 1 5 , 6 3 5}$. The Gross Domestic Product (GDP) per capita on purchasing power parity is $\mathbf{2 3 , 2 0 0}$ euro.

There are 584,000 households with an average size of $\mathbf{2 . 1}$ persons.

The average employment rate is $\mathbf{6 6 . 9 \%}$, while the level of tertiary education is 44.1\%. Table 10-1 summarizes the baseline values based on Eurostat data.

Table 10-1: Estonia - parameters for FW estimation at regional level

$\begin{array}{lllrrr}\text { Region } & \begin{array}{l}\text { GDP } \\ \text { PPP } \\ \text { (EUR) }\end{array} & \begin{array}{l}\text { Tertiary } \\ \text { education } \\ \text { level }\end{array} & \begin{array}{l}\text { Median } \\ \text { age }\end{array} & \text { Population } & \begin{array}{l}N^{\circ} \text { of } \\ \text { households }\end{array} \\ \text { Estonia } & 23,200 & 41.2 \% & 41.8 & 1,315,635 & 584,000\end{array}$

Source: author's elaboration on Eurostat data

Table 10-2 summarize the food waste estimations for the country as developed by on basis of simulations run with the REFRESH Road Map (Stewart et al, 2019)

Table 10-2: Estonia - FW estimation at regional level

\begin{tabular}{|c|c|c|c|c|c|c|}
\hline Region & $\begin{array}{l}\text { Household } \\
\text { FW (kg/ } \\
\text { year) }\end{array}$ & $\begin{array}{l}\text { Low } 95 \% \\
\text { (kg/ year) }\end{array}$ & $\begin{array}{l}\text { Up } 95 \% \\
\text { (kg/year) }\end{array}$ & $\begin{array}{l}\text { Total FW } \\
\text { (tons/year) }\end{array}$ & $\begin{array}{l}\text { Low } \\
95 \% \\
\text { (tons/ } \\
\text { year) }\end{array}$ & $\begin{array}{l}\text { Up 95\% } \\
\text { (tons/ } \\
\text { year) }\end{array}$ \\
\hline Estonia & 96.72 & 55.47 & 110.76 & 56,484 & 32,393 & 64,684 \\
\hline
\end{tabular}

Note: differences among the national values estimation and the sum of single regional values are due to computational approximations,

Source: REFRESH Road Map

The predicted food waste for Estonia, considering the actual regional values for GDP per capita and higher education level amounts to $\mathbf{9 6 . 7 2} \mathbf{k g}$ per household and an overall total of almost $\mathbf{5 6 , 4 8 4}$ tons per year. 


\section{Finland}

Finland is divided in 5 regions (NUTS 2): West Finland, Helsinki-Uusimaa, South Finland, North \& East Finland, and Åland.

According to 2017 Eurostat data, the population amounts to 5,503,297 The Gross Domestic Product (GDP) per capita on purchasing power parity is $\mathbf{3 2 , 1 0 0}$ euro, with relevant regional differences ranging from $\mathbf{2 6 , 7 0 0}$ euro per capita of North \& East Finland area to $\mathbf{4 1 , 6 0 0}$ euro per capita of the Helsinki-Uusimaa region.

There are 2,655,500 households, with an average size of $\mathbf{2 . 1}$ persons.

The average employment rate is $\mathbf{7 0} \%$, while the level of tertiary education is 44.5\%. Table 11-1 summarizes the baseline values based on Eurostat data.

Table 11-1: Finland - parameters for FW estimation at regional level

\begin{tabular}{|c|c|c|c|c|c|}
\hline Region & $\begin{array}{l}\text { GDP } \\
\text { PPP } \\
\text { (EUR) }\end{array}$ & $\begin{array}{l}\text { Tertiary } \\
\text { education level }\end{array}$ & $\begin{array}{l}\text { Median } \\
\text { age }\end{array}$ & Population & $\begin{array}{l}\text { No of } \\
\text { households }\end{array}$ \\
\hline West Finland & 28,500 & $42.2 \%$ & 43.0 & $1,380,593$ & 666,800 \\
\hline $\begin{array}{l}\text { Helsinki- } \\
\text { Uusimaa }\end{array}$ & 41,600 & $52.0 \%$ & 39.4 & $1,638,293$ & 766,600 \\
\hline South Finland & 28,800 & $40.9 \%$ & 45.8 & $1,159,174$ & 582,900 \\
\hline $\begin{array}{l}\text { North \& East } \\
\text { Finland }\end{array}$ & 26,700 & $39.5 \%$ & 44.4 & $1,296,023$ & 625,600 \\
\hline Åland & 37,200 & $36.4 \%$ & 44.2 & 29,214 & 13,600 \\
\hline Finland & 32,100 & $37.3 \%$ & 44.5 & $5,503,297$ & $2,655,500$ \\
\hline
\end{tabular}

Source: author's elaboration on Eurostat data

Figure 8 and Table 11-2 summarize the food waste estimations for the country, both at the regional and national level, as developed by on basis of simulations run with the REFRESH Road Map (Stewart et al, 2019). 
Figure 8: estimated FW per household in Finnish regions

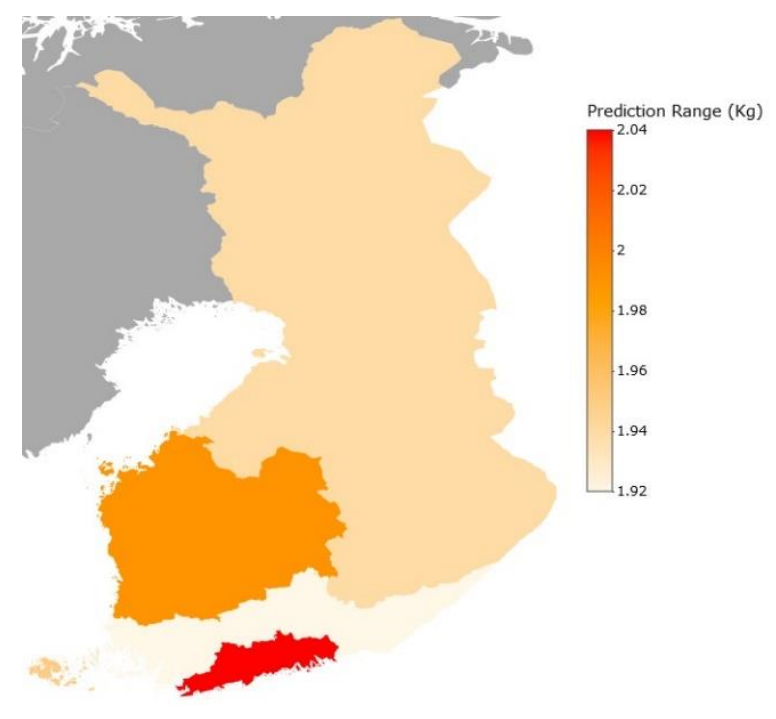

Table 11-2: Finland - FW estimation at regional level

\begin{tabular}{|c|c|c|c|c|c|c|}
\hline Region & $\begin{array}{l}\text { Household } \\
\text { FW }(\mathrm{kg} / \\
\text { year) }\end{array}$ & $\begin{array}{l}\text { Low } \\
95 \% \\
\text { (kg/ } \\
\text { year) }\end{array}$ & $\begin{array}{l}\text { Up } 95 \% \\
\text { (kg/year) }\end{array}$ & $\begin{array}{l}\text { Total FW } \\
\text { (tons/year) }\end{array}$ & $\begin{array}{l}\text { Low } 95 \% \\
\text { (tons/ } \\
\text { year) }\end{array}$ & $\begin{array}{l}\text { Up } 95 \% \\
\text { (tons/ } \\
\text { year) }\end{array}$ \\
\hline $\begin{array}{l}\text { Helsinki- } \\
\text { Uusimaa }\end{array}$ & 99.06 & 57.03 & 112.58 & 75,939 & 43,717 & 86,304 \\
\hline $\begin{array}{l}\text { West } \\
\text { Finland }\end{array}$ & 97.50 & 56.16 & 111.28 & 65,013 & 37,447 & 74,202 \\
\hline Åland & 95.16 & 54.60 & 108.94 & 1,294 & 743 & 1,482 \\
\hline $\begin{array}{l}\text { North \& } \\
\text { East } \\
\text { Finland }\end{array}$ & 94.90 & 54.43 & 108.68 & 59,369 & 34,049 & 67,990 \\
\hline $\begin{array}{l}\text { South } \\
\text { Finland }\end{array}$ & 93.86 & 53.73 & 107.64 & 54,711 & 31,321 & 62,743 \\
\hline Finland & 96.46 & 55.47 & 110.24 & 256,150 & 147,292 & 292,742 \\
\hline
\end{tabular}

Note: differences among the national values estimation and the sum of single regional values are due to computational approximations.

Source: REFRESH Road Map

The predicted food waste for Finland. considering the actual regional values for GDP per capita and higher education level amounts to $\mathbf{9 6 . 4 6} \mathrm{kg}$ per household and an

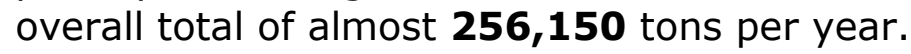

At the regional level the lowest estimated values of food waste are registered in South Finland. with an average household FW of $\mathbf{9 3 . 8 6} \mathbf{k g}$ per year. while the highest are recorded in Helsinki-Uusimaa with a value of $\mathbf{9 9 . 0 6} \mathbf{k g}$ per year. 


\section{France}

France is divided in 27 regions (NUTS 2): Île de France, Centre-Val de Loire, Bourgogne, Franche-Comté, Lower Normandy, Upper Normandy, Nord-Pas-deCalais, Picardy, Alsace, Champagne-Ardenne, Lorraine, Pays de la Loire, Brittany, Aquitaine, Limousin, Poitou-Charentes, Languedoc-Roussillon, Midi-Pyrénées, Auvergne, Rhône-Alpes, Provence-Alpes-Côte d'Azur, Corsica, Guadaloupe, Martinique, French Guyana, La Réunion, and Mayotte.

According to 2017 Eurostat data, the population amounts to $\mathbf{6 6 , 8 0 4 , 1 2 1}$ The Gross Domestic Product (GDP) per capita on purchasing power parity is $\mathbf{3 6 . 6 0 0}$ euro, with relevant regional differences ranging from 10,100 euro per capita of Mayotte overseas area to $\mathbf{5 2 , 1 0 0}$ euro per capita of the Île de France region.

There are 2,655,500 households, with an average size of $\mathbf{2 . 1}$ persons.

The average employment rate is $\mathbf{6 4 . 7 \%}$, while the level of tertiary education is $\mathbf{3 6 . 9} \%$. Table $12-1$ summarizes the baseline values based on Eurostat data.

Table 12-1: France - parameters for FW estimation at regional level

\begin{tabular}{|c|c|c|c|c|c|}
\hline Region & $\begin{array}{l}\text { GDP } \\
\text { PPP } \\
\text { (EUR) }\end{array}$ & $\begin{array}{l}\text { Tertiary } \\
\text { education level }\end{array}$ & $\begin{array}{l}\text { Median } \\
\text { age }\end{array}$ & Population & $\begin{array}{l}N^{\circ} \text { of } \\
\text { households }\end{array}$ \\
\hline Île de France & 52,100 & $49.4 \%$ & 37.2 & $12,152,461$ & $5,121,900$ \\
\hline $\begin{array}{l}\text { Centre-Val de } \\
\text { Loire }\end{array}$ & 24,800 & $31.8 \%$ & 43.9 & $2,575,917$ & $1,125,000$ \\
\hline Bourgogne & 24,400 & $30.1 \%$ & 45.5 & $1,633,186$ & 773,400 \\
\hline Franche-Comté & 23,100 & $30.4 \%$ & 42.6 & $1,179,419$ & 509,900 \\
\hline $\begin{array}{l}\text { Lower } \\
\text { Normandy }\end{array}$ & 23,900 & $28.3 \%$ & 44.8 & $1,473,939$ & 670,000 \\
\hline $\begin{array}{l}\text { Upper } \\
\text { Normandy }\end{array}$ & 26,000 & $27.0 \%$ & 41.3 & $1,858,680$ & 802,500 \\
\hline $\begin{array}{l}\text { Nord-Pas-de- } \\
\text { Calais }\end{array}$ & 24,500 & $31.9 \%$ & 38.8 & $4,071,241$ & $1,731,800$ \\
\hline Picardy & 22,100 & $28.0 \%$ & 40.8 & $1,930,305$ & 822,200 \\
\hline Alsace & 28,300 & $32.8 \%$ & 41.8 & $1,886,550$ & 821,400 \\
\hline $\begin{array}{l}\text { Champagne- } \\
\text { Ardenne }\end{array}$ & 25,000 & $28.0 \%$ & 42.7 & $1,328,826$ & 594,800 \\
\hline Lorraine & 22,200 & $29.0 \%$ & 42.9 & $2,331,204$ & $1,040,100$ \\
\hline Pays de la Loire & 27,600 & $34.5 \%$ & 41.7 & $3,756,053$ & $1,672,600$ \\
\hline Brittany & 26,000 & $37.5 \%$ & 43.6 & $3,315,901$ & $1,599,000$ \\
\hline
\end{tabular}




\begin{tabular}{llllll}
\hline Aquitaine & 26,900 & $35.3 \%$ & 44.2 & $3,414,116$ & $1,547,500$ \\
\hline Limousin & 23,600 & $32.0 \%$ & 47.5 & 734,296 & 367,200 \\
\hline $\begin{array}{l}\text { Poitou- } \\
\text { Charentes }\end{array}$ & 24,400 & $30.8 \%$ & 46.0 & $1,808,700$ & 814,000 \\
\hline $\begin{array}{l}\text { Languedoc- } \\
\text { Roussillon }\end{array}$ & 22,500 & $33.3 \%$ & 44.3 & $2,809,609$ & $1,298,500$ \\
\hline Midi-Pyrénées & 28,000 & $44.1 \%$ & 43.3 & $3,030,683$ & $1,390,600$ \\
\hline Auvergne & 23,500 & $29.5 \%$ & 45.7 & $1,363,035$ & 606,300 \\
\hline Rhône-Alpes & 30,700 & $40.7 \%$ & 40.2 & $6,594,307$ & $2,863,600$ \\
\hline $\begin{array}{l}\text { Provence-Alpes- } \\
\text { Côte d'Azur }\end{array}$ & 28,000 & $38.0 \%$ & 44.1 & $5,036,446$ & $2,279,600$ \\
\hline Corsica & 24,600 & $30.2 \%$ & 45.3 & 333,542 & 99,800 \\
\hline Guadaloupe & 21,500 & $21.2 \%$ & 43.2 & 426,449 & 190,800 \\
\hline Martinique & 22,300 & $25.5 \%$ & 46.0 & 372,666 & 178,100 \\
\hline French Guyana & 14,500 & $21.1 \%$ & 26.1 & 278,165 & 68,300 \\
\hline La Réunion & 20,500 & $21.9 \%$ & 35.6 & 857,816 & 325,300 \\
\hline Mayotte & 10,100 & $10.0 \%$ & 17.7 & 250,609 & 61,400 \\
\hline France & 30,600 & $36.9 \%$ & 41.4 & $66,804,121$ & $29,375,800$ \\
\hline & & & & & \\
\hline
\end{tabular}

Source: author's elaboration on Eurostat data

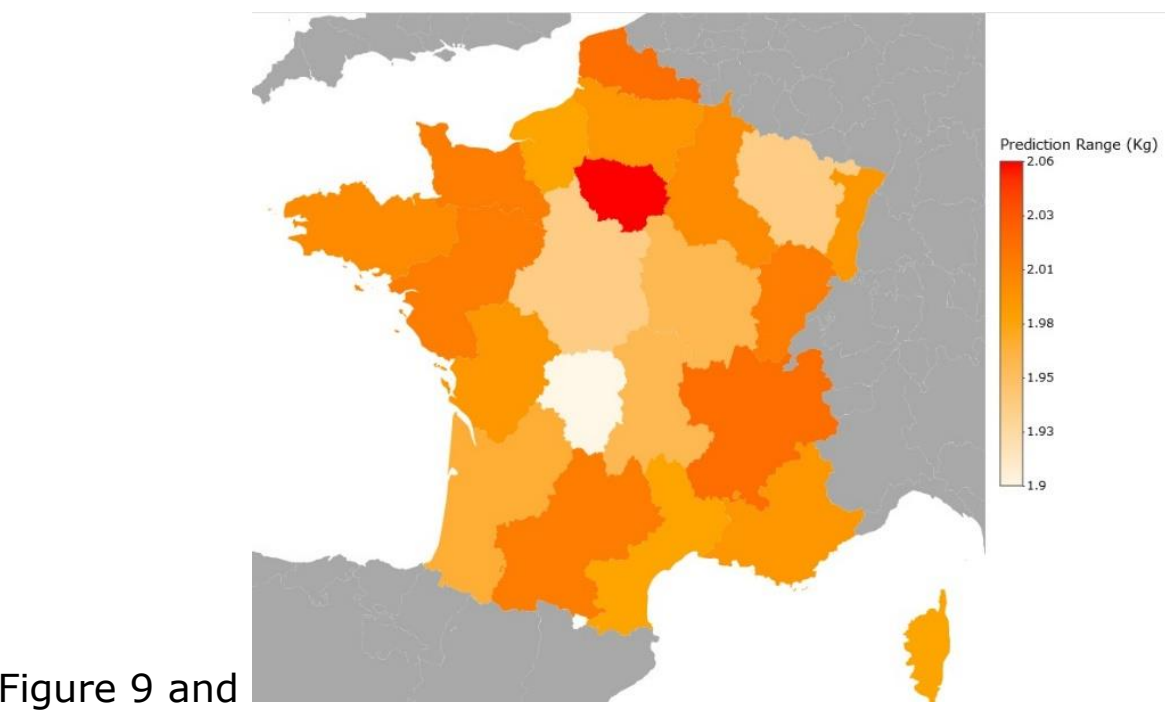

Table 12-2 summarize the food waste estimations for the country, both at the regional and national level, as developed by on basis of simulations run with the REFRESH Road Map (Stewart et al, 2019). 
Figure 9: estimated FW per household in French regions

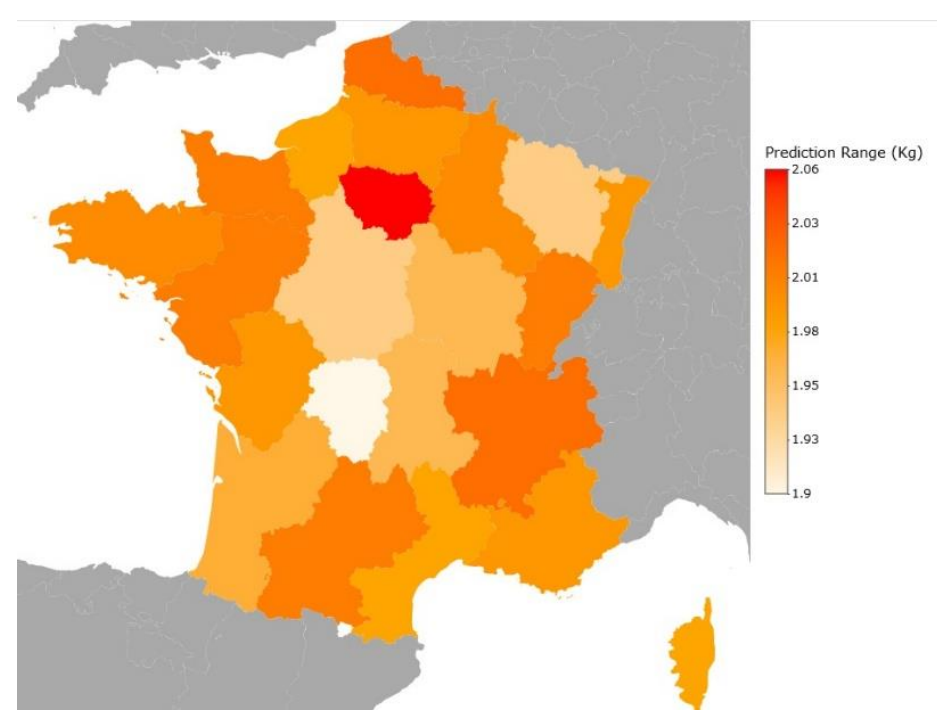

Table 12-2: France - FW estimation at regional level

\begin{tabular}{|c|c|c|c|c|c|c|}
\hline Region & $\begin{array}{l}\text { Household } \\
\text { FW (kg/ } \\
\text { year) }\end{array}$ & $\begin{array}{l}\text { Low } \\
95 \% \\
(\mathrm{~kg} / \\
\text { year) }\end{array}$ & $\begin{array}{l}\text { Up } 95 \% \\
\text { (kg/year) }\end{array}$ & $\begin{array}{l}\text { Total FW } \\
\text { (tons/year) }\end{array}$ & $\begin{array}{l}\text { Low 95\% } \\
\text { (tons/ } \\
\text { year) }\end{array}$ & $\begin{array}{l}\text { Up } 95 \% \\
\text { (tons/ } \\
\text { year) }\end{array}$ \\
\hline Mayotte & 120.38 & 69.68 & 136.5 & 7,391 & 4,278 & 8,381 \\
\hline $\begin{array}{l}\text { French } \\
\text { Guyana }\end{array}$ & 113.88 & 66.21 & 128.96 & 7,778 & 4,522 & 8,808 \\
\hline La Réunion & 104.00 & 59.63 & 119.08 & 33,831 & 19,397 & 38,737 \\
\hline Île de France & 101.66 & 58.93 & 115.44 & 520,692 & 301,851 & 591,272 \\
\hline $\begin{array}{l}\text { Nord-Pas- } \\
\text { de-Calais }\end{array}$ & 99.32 & 57.20 & 113.1 & 172,002 & 99,059 & 195,867 \\
\hline $\begin{array}{l}\text { Midi- } \\
\text { Pyrénées }\end{array}$ & 99.32 & 57.20 & 113.1 & 138,114 & 79,542 & 157,277 \\
\hline Rhône-Alpes & 99.32 & 57.55 & 113.1 & 284,413 & 164,791 & 323,873 \\
\hline $\begin{array}{l}\text { Franche- } \\
\text { Comté }\end{array}$ & 98.54 & 56.85 & 112.06 & 50,246 & 28,990 & 57,139 \\
\hline $\begin{array}{l}\text { Pays de la } \\
\text { Loire }\end{array}$ & 98.54 & 56.85 & 112.06 & 164,818 & 95,093 & 187,432 \\
\hline $\begin{array}{l}\text { Lower } \\
\text { Normandy }\end{array}$ & 98.28 & 56.51 & 111.8 & 65,848 & 37,859 & 74,906 \\
\hline Brittany & 98.28 & 56.51 & 111.8 & 157,150 & 90,354 & 178,768 \\
\hline
\end{tabular}




\begin{tabular}{|c|c|c|c|c|c|c|}
\hline Alsace & 97.76 & 56.16 & 111.28 & 80,300 & 46,130 & 91,405 \\
\hline $\begin{array}{l}\text { Champagne- } \\
\text { Ardenne }\end{array}$ & 97.76 & 56.16 & 111.28 & 58,148 & 33,404 & 66,189 \\
\hline $\begin{array}{l}\text { Provence- } \\
\text { Alpes-Côte } \\
\text { d'Azur }\end{array}$ & 97.76 & 56.16 & 111.28 & 222,854 & 128,022 & 253,674 \\
\hline $\begin{array}{l}\text { Poitou- } \\
\text { Charentes }\end{array}$ & 97.50 & 56.16 & 111.28 & 79,365 & 45,714 & 90,582 \\
\hline Picardy & 97.24 & 55.99 & 111.02 & 79,951 & 46,032 & 91,281 \\
\hline $\begin{array}{l}\text { Languedoc- } \\
\text { Roussillon }\end{array}$ & 97.24 & 55.81 & 110.76 & 126,266 & 72,474 & 143,822 \\
\hline Corsica & 97.24 & 55.81 & 110.76 & 9,705 & 5,570 & 11,054 \\
\hline $\begin{array}{l}\text { Upper } \\
\text { Normandy }\end{array}$ & 96.72 & 55.64 & 110.24 & 77,618 & 44,651 & 88,468 \\
\hline Aquitaine & 96.72 & 55.81 & 110.24 & 149,674 & 86,371 & 170,596 \\
\hline Guadaloupe & 96.46 & 55.47 & 109.98 & 18,405 & 10,583 & 20,984 \\
\hline Bourgogne & 96.20 & 55.12 & 110.24 & 74,401 & 42,630 & 85,260 \\
\hline Auvergne & 95.94 & 55.12 & 109.46 & 58,168 & 33,419 & 66,366 \\
\hline Lorraine & 95.16 & 54.43 & 108.68 & 98,976 & 56,609 & 113,038 \\
\hline $\begin{array}{l}\text { Centre-Val } \\
\text { de Loire }\end{array}$ & 94.64 & 54.43 & 108.16 & 106,470 & 61,230 & 121,680 \\
\hline Limousin & 92.56 & 52.69 & 106.6 & 33,988 & 19,349 & 39,144 \\
\hline Martinique & 92.56 & 53.04 & 106.08 & 16,485 & 9,446 & 18,893 \\
\hline France & 97.76 & 56.33 & 111.8 & 2.871 .778 & 1.654 .837 & 3.284 .214 \\
\hline
\end{tabular}

Note: differences among the national values estimation and the sum of single regional values are due to computational approximations.

Source: REFRESH Road Map

The predicted food waste for France. considering the actual regional values for GDP per capita and higher education level amounts to $\mathbf{9 7 . 7 6} \mathrm{kg}$ per household and an overall total of almost $\mathbf{2 , 8 7 1 , 7 7 8}$ tons per year.

At the regional level the lowest estimated values of food waste are registered in Martinique. with an average household FW of $\mathbf{9 2 . 5 6} \mathrm{kg}$ per year. while the highest are recorded in Mayotte with a value of $\mathbf{1 2 0 . 3 8} \mathrm{kg}$ per year. 


\section{Germany}

Germany is divided in 38 regions (NUTS 2): Stuttgart, Karlsrue, Freiburg, Tübingen, Oberbayern, Niederbayern, Oberpfalz, Oberfranken, Mittelfranken, Unterfranken, Schwaben, Berlin, Brandenburg, Bremen, Hamburg, Darmstadt, Giessen, Kassel, Mecklenburg-Vorpommern, Braunshweig, Hannover, Lüneburg, Weser-Ems, Düsseldorf, Köln, Münster, Detmold, Arnsberg, Koblenz, Trier, Rheinhessen-Pfalz, Saarland, Chemnitz, Dresden, Leipzig, Saxony-Anhalt, Schleswig-Holstein, and Thüringen.

According to 2017 Eurostat data, the population amounts to $\mathbf{8 2 , 5 2 1 , 6 5 3}$ The Gross Domestic Product (GDP) per capita on purchasing power parity is $\mathbf{3 6 , 4 0 0}$ euro, with consistent regional differences ranging from 24,500 euro per capita of Mecklenburg-Vorpommern area to 59,500 euro per capita of the Hamburg region. There are 40,722,600 households, with an average size of $\mathbf{2}$ persons, and the number of households is, according to Eurostat data.

The average employment rate is $\mathbf{7 5 . 2} \%$, while the level of tertiary education is $\mathbf{2 9 . 1 \%}$. Table 13-1 summarizes the baseline values based on Eurostat data.

Table 13-1: Germany - parameters for FW estimation at regional level

\begin{tabular}{|c|c|c|c|c|c|}
\hline Region & $\begin{array}{l}\text { GDP } \\
\text { PPP } \\
\text { (EUR) }\end{array}$ & $\begin{array}{l}\text { Tertiary } \\
\text { education } \\
\text { level }\end{array}$ & $\begin{array}{l}\text { Median } \\
\text { age }\end{array}$ & Population & $\begin{array}{l}N^{\circ} \text { of } \\
\text { households }\end{array}$ \\
\hline Stuttgart & 46,900 & $32.7 \%$ & 44.0 & $4,098,278$ & $1,916,400$ \\
\hline Karlsruhe & 40,100 & $31.2 \%$ & 44.6 & $2,779,314$ & $1,347,100$ \\
\hline Freiburg & 34,900 & $29.5 \%$ & 44.9 & $2,239,734$ & $1,067,800$ \\
\hline Tübingen & 39,700 & $30.6 \%$ & 44.2 & $1,834,567$ & 839,300 \\
\hline Oberbayern & 52,000 & $40.6 \%$ & 43.2 & $4,633,323$ & $2,266,900$ \\
\hline Niederbayern & 35,800 & $21.5 \%$ & 45.6 & $1,219,397$ & 551,600 \\
\hline Oberpfalz & 38,000 & $24.9 \%$ & 45.4 & $1,098,378$ & 539,900 \\
\hline Oberfranken & 34,000 & $24.7 \%$ & 47.4 & $1,062,394$ & 523,300 \\
\hline Mittelfranken & 39,900 & $30.7 \%$ & 44.9 & $1,750,059$ & 882,500 \\
\hline Unterfranken & 36,900 & $27.4 \%$ & 46.6 & $1,309,209$ & 634,400 \\
\hline Schwaben & 36,200 & $26.7 \%$ & 45.0 & $1,857,991$ & 890,900 \\
\hline Berlin & 34,800 & $42.1 \%$ & 41.7 & $3,574,830$ & $1,982,000$ \\
\hline Brandenburg & 25,600 & $28.2 \%$ & 49.9 & $2,494,648$ & $1,239,900$ \\
\hline Bremen & 45,700 & $28.4 \%$ & 44.0 & 678,753 & 360,600 \\
\hline
\end{tabular}




\begin{tabular}{|c|c|c|c|c|c|}
\hline Hamburg & 59,500 & $36.9 \%$ & 41.1 & $1,810,438$ & 980,300 \\
\hline Darmstadt & 46,400 & $33.9 \%$ & 44.3 & $3,951,234$ & $1,926,200$ \\
\hline Giessen & 30,700 & $27.5 \%$ & 45.4 & $1,043,643$ & 498,000 \\
\hline Kassel & 33,900 & $25.4 \%$ & 47.2 & $1,218,211$ & 588,400 \\
\hline $\begin{array}{l}\text { Mecklenburg- } \\
\text { Vorpommern }\end{array}$ & 24,500 & $25.5 \%$ & 49.8 & $1,610,674$ & 817,300 \\
\hline Braunschweig & 41,500 & $28.5 \%$ & 46.9 & $1,595,609$ & 829,100 \\
\hline Hannover & 34,900 & $27.4 \%$ & 46.6 & $2,139,976$ & $1,082,800$ \\
\hline Lüneburg & 25,800 & $23.5 \%$ & 47.3 & $1,703,945$ & 816,900 \\
\hline Weser-Ems & 32,600 & $21.5 \%$ & 45.2 & $2,506,155$ & $1,182,900$ \\
\hline Düsseldorf & 37,900 & $25.9 \%$ & 46.1 & $5,190,790$ & $2,582,400$ \\
\hline Köln & 39,000 & $30.5 \%$ & 44.5 & $4,439,416$ & $2,191,000$ \\
\hline Münster & 30,700 & $24.4 \%$ & 45.4 & $2,619,376$ & $1,230,000$ \\
\hline Detmold & 35,000 & $23.5 \%$ & 45.2 & $2,054,205$ & 964,000 \\
\hline Arnsberg & 31,900 & $22.7 \%$ & 46.4 & $3,586,313$ & $1,745,800$ \\
\hline Koblenz & 31,500 & $25.5 \%$ & 47.6 & $1,492,187$ & 698,100 \\
\hline Trier & 28,800 & $28.4 \%$ & 45.9 & 528,728 & 257,100 \\
\hline $\begin{array}{l}\text { Rheinhessen- } \\
\text { Pfalz }\end{array}$ & 34,800 & $28.5 \%$ & 46.2 & $2,045,138$ & 980,000 \\
\hline Saarland & 32,700 & $24.5 \%$ & 48.7 & 996,651 & 491,000 \\
\hline Chemnitz & 27,900 & $32.2 \%$ & 48.3 & $1,600,155$ & 820,100 \\
\hline Dresden & 26,000 & $24.7 \%$ & 51.3 & $1,454,144$ & 757,400 \\
\hline Leipzig & 29,000 & $32.9 \%$ & 45.6 & $1,027,484$ & 544,900 \\
\hline Saxony-Anhalt & 25,200 & $21.5 \%$ & 50.4 & $2,236,252$ & $1,165,300$ \\
\hline $\begin{array}{l}\text { Schleswig- } \\
\text { Holstein }\end{array}$ & 29,800 & $24.4 \%$ & 47.2 & $2,881,926$ & $1,440,100$ \\
\hline Thüringen & 26,500 & $28.3 \%$ & 49.7 & $2,158,128$ & $1,091,100$ \\
\hline Germany & 36,400 & $29.1 \%$ & 45.9 & $82,521,653$ & $40,722,600$ \\
\hline
\end{tabular}

Source: author's elaboration on Eurostat data 
Figure 10 and

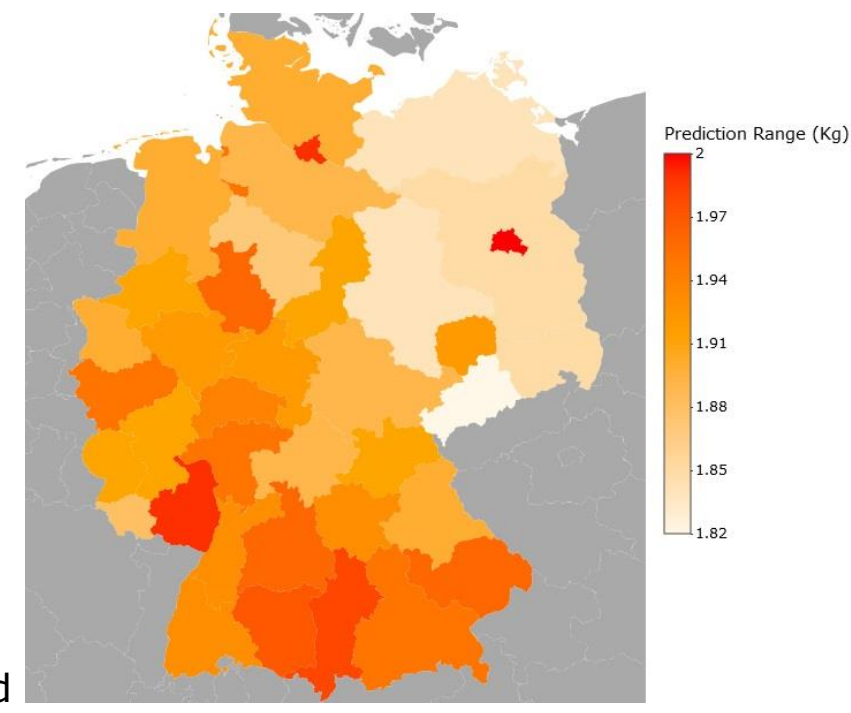

Table 13-2 summarize the food waste estimations for the country, both at the regional and national level, as developed by on basis of simulations run with the REFRESH Road Map (Stewart et al, 2019).

Figure 10: estimated FW per household in German regions

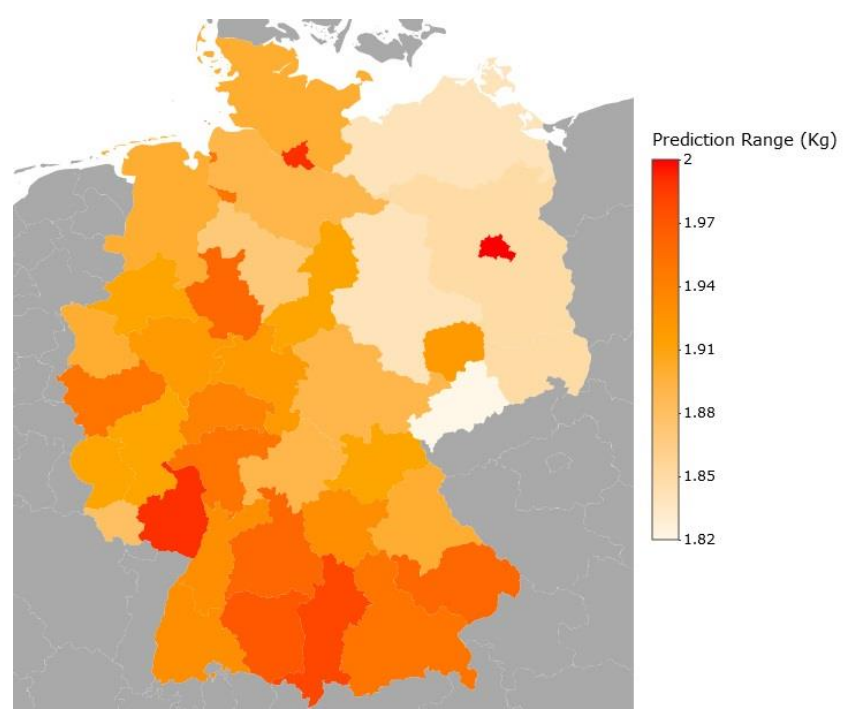

Table 13-2: Germany - FW estimation at regional level

\begin{tabular}{|c|c|c|c|c|c|c|}
\hline Region & $\begin{array}{l}\text { Household } \\
\text { FW ( } \mathrm{kg} / \\
\text { year) }\end{array}$ & $\begin{array}{l}\text { Low } \\
95 \% \\
\text { (kg/ } \\
\text { year) }\end{array}$ & $\begin{array}{l}\text { Up } 95 \% \\
\text { (kg/year) }\end{array}$ & $\begin{array}{l}\text { Total } F W \\
\text { (tons/year) }\end{array}$ & $\begin{array}{l}\text { Low 95\% } \\
\text { (tons/ } \\
\text { year) }\end{array}$ & $\begin{array}{l}\text { Up } 95 \% \\
\text { (tons/ } \\
\text { year) }\end{array}$ \\
\hline Berlin & 99.06 & 57.20 & 112.84 & 196,337 & 113,370 & 223,649 \\
\hline Hamburg & 97.50 & 55.99 & 111.28 & 95,579 & 54,884 & 109,088 \\
\hline $\begin{array}{l}\text { Rheinhessen- } \\
\text { Pfalz }\end{array}$ & 97.76 & 56.16 & 111.8 & 95,805 & 55,037 & 109,564 \\
\hline
\end{tabular}




\begin{tabular}{|c|c|c|c|c|c|c|}
\hline Schwaben & 96.98 & 55.81 & 110.24 & 86,399 & 49,724 & 98,213 \\
\hline Tübingen & 96.72 & 55.47 & 110.76 & 81,177 & 46,553 & 92,961 \\
\hline Stuttgart & 96.20 & 55.47 & 109.72 & 184,358 & 106,296 & 210,267 \\
\hline Oberbayern & 95.68 & 55.12 & 109.2 & 216,897 & 124,952 & 247,545 \\
\hline Niederbayern & 95.68 & 54.77 & 109.72 & 52,777 & 30,213 & 60,522 \\
\hline Bremen & 95.68 & 54.95 & 109.2 & 34,502 & 19,814 & 39,378 \\
\hline Darmstadt & 95.68 & 54.95 & 109.46 & 184,299 & 105,838 & 210,842 \\
\hline Köln & 95.68 & 54.77 & 109.72 & 209,635 & 120,008 & 240,397 \\
\hline Detmold & 95.68 & 55.12 & 109.2 & 92,236 & 53,136 & 105,269 \\
\hline Giessen & 95.16 & 54.43 & 108.68 & 47,390 & 27,104 & 54,123 \\
\hline Karlsruhe & 94.64 & 54.08 & 108.16 & 127,490 & 72,851 & 145,702 \\
\hline Freiburg & 94.64 & 54.25 & 108.16 & 101,057 & 57,932 & 115,493 \\
\hline Mittelfranken & 94.64 & 54.43 & 108.16 & 83,520 & 48,032 & 95,451 \\
\hline Kassel & 94.12 & 54.08 & 107.64 & 55,380 & 31,821 & 63,335 \\
\hline Leipzig & 94.12 & 54.08 & 107.9 & 51,286 & 29,468 & 58,795 \\
\hline Oberfranken & 93.60 & 53.56 & 107.12 & 48,981 & 28,028 & 56,056 \\
\hline Braunschweig & 93.60 & 53.73 & 107.12 & 77,604 & 44,550 & 88,813 \\
\hline Arnsberg & 93.60 & 53.73 & 107.38 & 163,407 & 93,808 & 187,464 \\
\hline Koblenz & 93.60 & 53.39 & 107.12 & 65,342 & 37,269 & 74,780 \\
\hline Trier & 93.60 & 53.39 & 107.12 & 24,065 & 13,726 & 27,541 \\
\hline Düsseldorf & 92.82 & 53.04 & 106.6 & 239,698 & 136,970 & 275,284 \\
\hline Münster & 93.08 & 53.39 & 106.6 & 114,488 & 65,666 & 131,118 \\
\hline $\begin{array}{l}\text { Schleswig- } \\
\text { Holstein }\end{array}$ & 93.08 & 53.04 & 106.6 & 134,045 & 76,383 & 153,515 \\
\hline Oberpfalz & 92.56 & 53.04 & 106.08 & 49,973 & 28,636 & 57,273 \\
\hline Unterfranken & 92.56 & 52.69 & 106.08 & 58,720 & 33,429 & 67,297 \\
\hline Lüneburg & 92.56 & 53.04 & 106.34 & 75,612 & 43,328 & 86,869 \\
\hline Weser-Ems & 92.56 & 52.87 & 106.08 & 109,489 & 62,536 & 125,482 \\
\hline
\end{tabular}




\begin{tabular}{lrlr|rrr|}
\hline Thüringen & 92.56 & 53.04 & 106.08 & 100,992 & 57,872 & 115,744 \\
\hline Saarland & 92.04 & 52.52 & 105.56 & 45,192 & 25,787 & 51,830 \\
\hline Hannover & 91.52 & 52.35 & 105.04 & 99,098 & 56,681 & 113,737 \\
\hline $\begin{array}{l}\text { Brandenburg } \\
\text { Mecklenburg- }\end{array}$ & 90.48 & 51.65 & 104.26 & 112,186 & 64,045 & 129,272 \\
\hline $\begin{array}{l}\text { Vorpommern } \\
\text { Chemnitz }\end{array}$ & 90.22 & 51.31 & 103.74 & 73,737 & 41,933 & 84,787 \\
\hline $\begin{array}{l}\text { Saxony- } \\
\text { Anhalt }\end{array}$ & 90.48 & 51.65 & 104 & 74,203 & 42,361 & 85,290 \\
\hline Dresden & 89.96 & 51.31 & 103.22 & 104,830 & 59,788 & 120,282 \\
\hline Germany & 88.92 & 50.61 & 102.96 & 67,348 & 38,335 & 77,982 \\
\hline
\end{tabular}

Note: differences among the national values estimation and the sum of single regional values are due to computational approximations.

Source: REFRESH Road Map

The predicted food waste for Germany, considering the actual regional values for GDP per capita and higher education level amounts to $\mathbf{9 4 . 1 2} \mathrm{kg}$ per household and an overall total of almost $\mathbf{3}, \mathbf{8 3 2}, \mathbf{8 1 1}$ tons per year.

At the regional level the lowest estimated values of food waste are registered in Dresden, with an average household FW of $\mathbf{8 8 . 9 2} \mathrm{kg}$ per year, while the highest are recorded in Berlin, with a value of $\mathbf{9 9 . 0 6} \mathrm{kg}$ per year. 


\section{Greece}

Greece is divided in 13 regions (NUTS 2): Attica, North Aegan, South Aegan, Crete, Eastern Macedonia and Thrace, Central Macedonia, Western Macedonia, Epirus, Thessaly, Ionian Island, Western Greece, Central Greece, and Peloponnese.

According to 2017 Eurostat data, the population amounts to $\mathbf{1 0 , 7 3 8 , 1 9 3}$ The Gross Domestic Product (GDP) per capita on purchasing power parity is $\mathbf{1 9 , 8 0 0}$ euro, with some regional differences ranging from 13,600 euro per capita of Eastern Macedonia and Thrace area to the $\mathbf{2 6 , 8 0 0}$ euro per capita of the Attica region.

There are 4,393,900 households, with an average size of $\mathbf{2 . 3}$ persons.

The average employment rate is $\mathbf{5 3 . 5 \%}$, while the level of tertiary education is $\mathbf{3 1 . 7 \%}$. Table 14-1 summarizes the baseline values based on Eurostat data.

Table 14-1: Greece - parameters for FW estimation at regional level

\begin{tabular}{|c|c|c|c|c|c|}
\hline Region & $\begin{array}{l}\text { GDP PPP } \\
\text { (EUR) }\end{array}$ & $\begin{array}{l}\text { Tertiary } \\
\text { education } \\
\text { level }\end{array}$ & $\begin{array}{l}\text { Median } \\
\text { age }\end{array}$ & Population & $\begin{array}{l}N^{\circ} \text { of } \\
\text { households }\end{array}$ \\
\hline Attica & 26.800 & $39.3 \%$ & 43.7 & $3,773,559$ & 245,800 \\
\hline North Aegan & 14.200 & $24.5 \%$ & 43.1 & 203,700 & 761,100 \\
\hline South Aegan & 21.300 & $20.8 \%$ & 41.0 & 338,383 & 101,700 \\
\hline Crete & 16.700 & $26.6 \%$ & 41.4 & 632,674 & 148,700 \\
\hline $\begin{array}{l}\text { Eastern } \\
\text { Macedonia and } \\
\text { Thrace }\end{array}$ & 13.600 & $25.1 \%$ & 44.2 & 602,799 & 273,700 \\
\hline $\begin{array}{l}\text { Central } \\
\text { Macedonia }\end{array}$ & 15.700 & $31.7 \%$ & 44.5 & $1,880,122$ & 82,800 \\
\hline $\begin{array}{l}\text { Western } \\
\text { Macedonia }\end{array}$ & 17.500 & $26.0 \%$ & 46.5 & 271,488 & 267,400 \\
\hline Epirus & 14.100 & $33.8 \%$ & 47.3 & 335,250 & 219,000 \\
\hline Thessaly & 15.400 & $32.1 \%$ & 45.8 & 725,874 & 227,800 \\
\hline Ionian Island & 18.200 & $22.8 \%$ & 45.6 & 205,431 & $1,597,000$ \\
\hline Western Greece & 14.600 & $21.9 \%$ & 44.0 & 663,970 & 82,500 \\
\hline Central Greece & 18.200 & $23.6 \%$ & 45.2 & 555,761 & 131,000 \\
\hline Peloponnese & 16.700 & $23.8 \%$ & 46.5 & 579,182 & 255,600 \\
\hline Greece & 19.800 & $31.7 \%$ & 44.2 & $10,768,193$ & $4,393,900$ \\
\hline
\end{tabular}

Source: author's elaboration on Eurostat data 
Figure 11 and

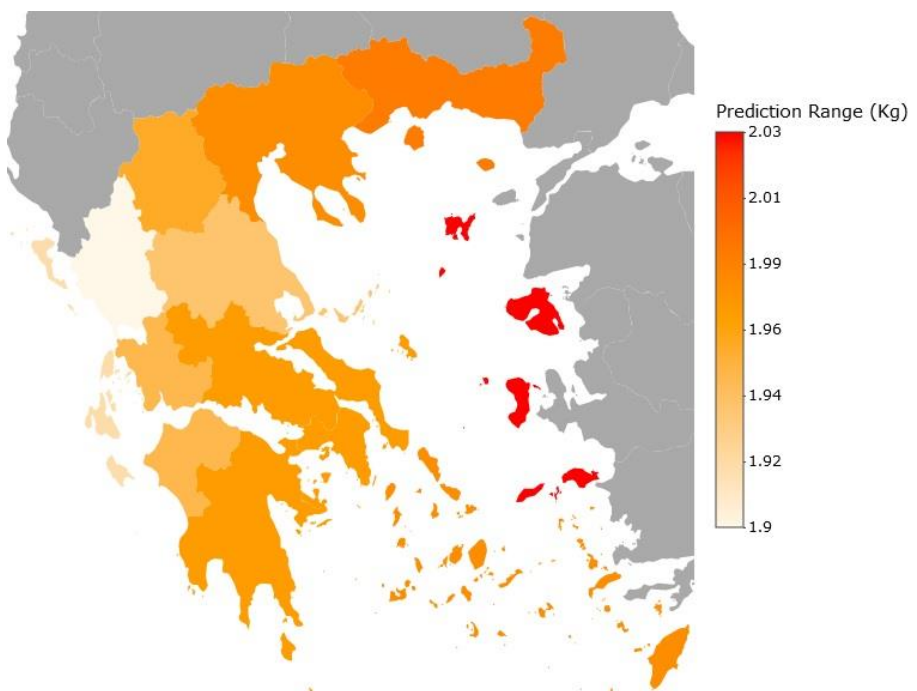

Table 14-2 summarize the food waste estimations for the country, both at the regional and national level, as developed by on basis of simulations run with the REFRESH Road Map (Stewart et al, 2019).

Figure 11: estimated FW per household in Greek regions

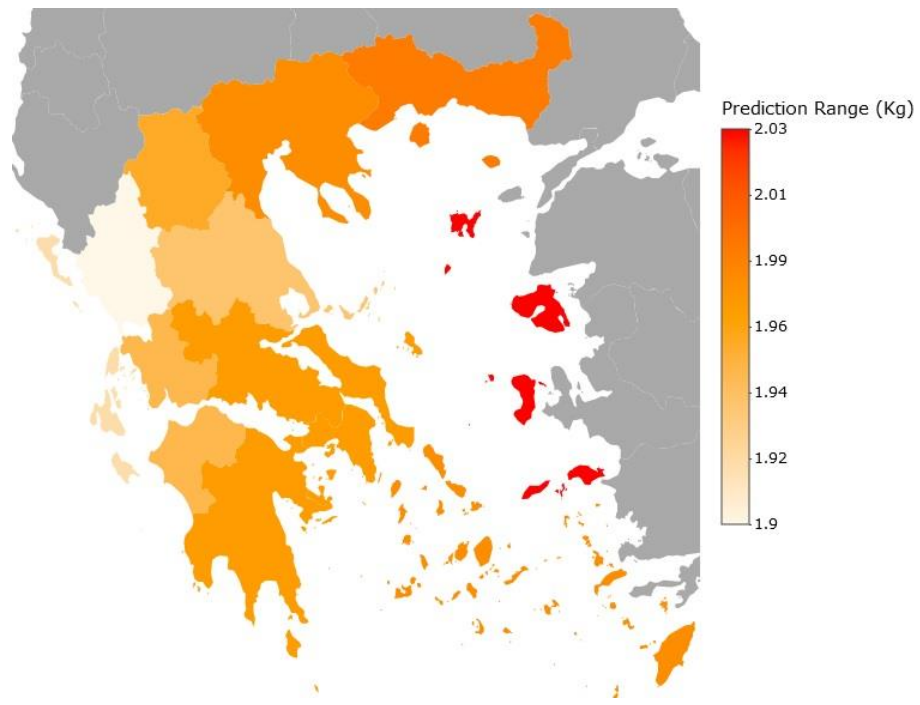

Table 14-2: Greece - FW estimation at regional level

\begin{tabular}{|c|c|c|c|c|c|c|}
\hline Region & $\begin{array}{l}\text { Household } \\
\text { FW (kg/ } \\
\text { year) }\end{array}$ & $\begin{array}{l}\text { Low } 95 \% \\
\text { (kg/ year) }\end{array}$ & $\begin{array}{l}\text { Up } 95 \% \\
\text { (kg/year) }\end{array}$ & $\begin{array}{l}\text { Total } F W \\
\text { (tons/year) }\end{array}$ & $\begin{array}{l}\text { Low } \\
95 \% \\
\text { (tons/ } \\
\text { year) }\end{array}$ & $\begin{array}{l}\text { Up } 95 \% \\
\text { (tons/ } \\
\text { year) }\end{array}$ \\
\hline North Aegan & 99.32 & 57.55 & 112.84 & 75,592 & 43,799 & 85,883 \\
\hline Crete & 98.28 & 56.51 & 111.8 & 14,614 & 8,403 & 16,625 \\
\hline $\begin{array}{l}\text { Central } \\
\text { Macedonia }\end{array}$ & 97.50 & 55.99 & 111.28 & 8,073 & 4,636 & 9,214 \\
\hline
\end{tabular}




\begin{tabular}{llll|rrr|}
\hline Attica & 96.98 & 55.81 & 110.76 & 23,838 & 13,719 & 27,225 \\
$\begin{array}{l}\text { Eastern } \\
\begin{array}{l}\text { Macedonia } \\
\text { and Thrace }\end{array}\end{array}$ & 97.24 & 56.16 & 110.76 & 26,615 & 15,371 & 30,315 \\
\hline $\begin{array}{l}\text { South Aegan } \\
\text { Western }\end{array}$ & 96.72 & 55.47 & 110.24 & 9,836 & 5,641 & 11,211 \\
\hline $\begin{array}{l}\text { Macedonia } \\
\text { Central }\end{array}$ & 96.20 & 55.47 & 109.72 & 25,724 & 14,832 & 29,339 \\
Greece & 96.20 & 55.47 & 110.24 & 12,602 & 7,266 & 14,441 \\
\hline $\begin{array}{l}\text { Peloponnese } \\
\text { Thessaly }\end{array}$ & 96.20 & 55.47 & 109.72 & 24,589 & 14,177 & 28,044 \\
\hline $\begin{array}{l}\text { Western } \\
\text { Greece }\end{array}$ & 95.16 & 54.60 & 108.68 & 21,677 & 12,438 & 24,757 \\
\hline Ionian Island & 95.16 & 54.77 & 108.68 & 7,851 & 4,519 & 8,966 \\
\hline Epirus & 93.86 & 53.73 & 107.64 & 149,894 & 85,812 & 171,901 \\
\hline Greece & 93.34 & 53.56 & 106.86 & 20,441 & 11,730 & 23,402 \\
\hline & 96.46 & 55.47 & 110.24 & 423,836 & 243,715 & 484,384 \\
\hline
\end{tabular}

Note: differences among the national values estimation and the sum of single regional values are due to computational approximations.

Source: REFRESH Road Map

The predicted food waste for Greece, considering the actual regional values for GDP per capita and higher education level amounts to $\mathbf{9 6 . 4 6} \mathrm{kg}$ per household and an overall total of almost $\mathbf{4 2 3 , 8 3 6}$ tons per year.

At the regional level the lowest estimated values of food waste are registered in Epirus, with an average household FW of $\mathbf{9 3 . 3 4} \mathbf{k g}$ per year, while the highest are recorded in North Aegan, with a value of $\mathbf{9 9 . 3 2} \mathbf{~ k g}$ per year. 


\section{Hungary}

Hungary is divided in 8 regions (NUTS 2): Budapest, Pest, Central Transdanubia, Western Transdanubia, Southern Transdanubia, Northern Hungary, Northern Great Plain, and Southern Great Plain.

According to 2017 Eurostat data, the population amounts to $\mathbf{9 , 7 9 7 , 5 6 1}$ The Gross Domestic Product (GDP) per capita on purchasing power parity is $\mathbf{2 0 , 0 0 0}$ euro, with relevant regional differences ranging from 12,700 euro per capita of Northern Great Plain area to 41,100 euro per capita of the Budapest region.

There are 4,131,400 households, with an average size of $\mathbf{2 . 3}$ persons.

The average employment rate is $\mathbf{6 8 . 2} \%$, while the level of tertiary education reaches $\mathbf{2 5 . 1 \%}$. Table $\mathbf{1 5 - 1}$ summarizes the baseline values based on Eurostat data.

Table 15-1: Hungary - parameters for FW estimation at regional level

\begin{tabular}{|c|c|c|c|c|c|}
\hline Region & $\begin{array}{l}\text { GDP PPP } \\
\text { (EUR) }\end{array}$ & $\begin{array}{l}\text { Tertiary } \\
\text { education } \\
\text { level }\end{array}$ & $\begin{array}{l}\text { Median } \\
\text { age }\end{array}$ & Population & $\begin{array}{l}N^{\circ} \text { of } \\
\text { households }\end{array}$ \\
\hline Budapest & 41,100 & $46.5 \%$ & 41.8 & $1,752,704$ & $1,307,800$ \\
\hline Pest & 15,800 & $26.4 \%$ & 41.0 & $1,247,372$ & 503,100 \\
\hline $\begin{array}{l}\text { Central } \\
\text { Transdanubia }\end{array}$ & 18,400 & $19.9 \%$ & 42.6 & $1,056,097$ & 438,700 \\
\hline $\begin{array}{l}\text { Western } \\
\text { Transdanubia }\end{array}$ & 21,100 & $20.5 \%$ & 42.9 & 983,251 & 404,600 \\
\hline $\begin{array}{l}\text { Southern } \\
\text { Transdanubia }\end{array}$ & 13,200 & $18.1 \%$ & 44.1 & 894,223 & 376,500 \\
\hline $\begin{array}{l}\text { Northern } \\
\text { Hungary }\end{array}$ & 13,500 & $17.4 \%$ & 42.5 & $1,143,902$ & 465,000 \\
\hline $\begin{array}{l}\text { Northern Great } \\
\text { Plain }\end{array}$ & 12,700 & $18.5 \%$ & 41.4 & $1,468,088$ & 581,100 \\
\hline $\begin{array}{l}\text { Southern Great } \\
\text { Plain }\end{array}$ & 14,200 & $20.9 \%$ & 43.5 & $1,251,924$ & 557,700 \\
\hline Hungary & 20,000 & $25.1 \%$ & 42.3 & $9,797,561$ & $4,131,400$ \\
\hline
\end{tabular}

Source: author's elaboration on Eurostat data 
Figure 12 and

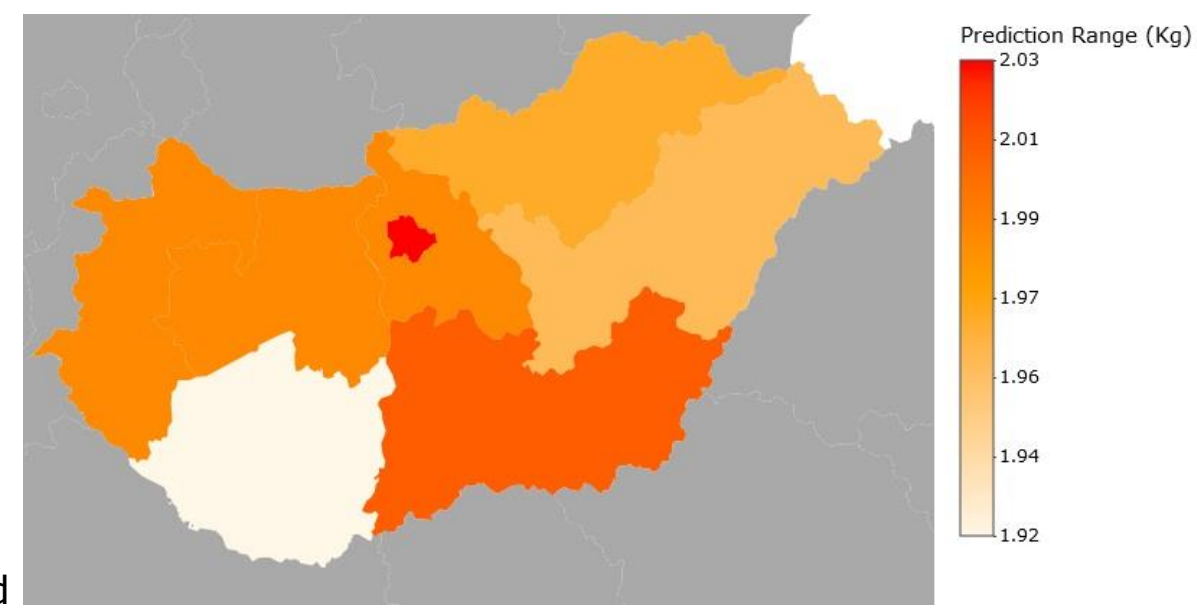

Table 15-2 summarize the food waste estimations for the country, both at the regional and national level, as developed by on basis of simulations run with the REFRESH Road Map (Stewart et al, 2019).

Figure 12: estimated FW per household in Hungarian regions

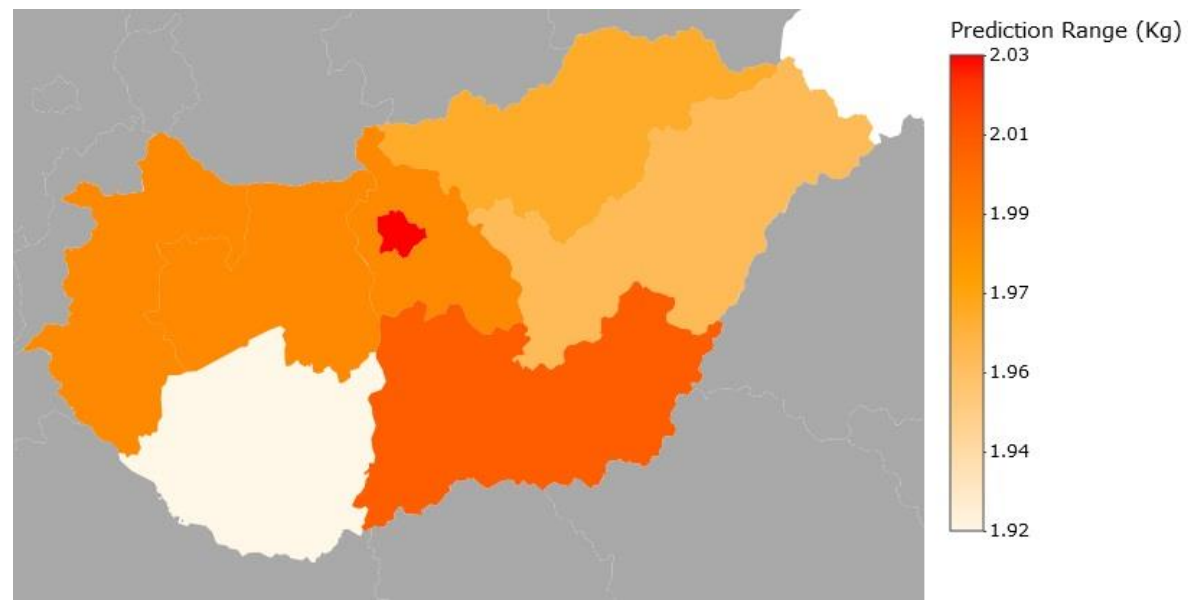

Table 15-2: Hungary - FW estimation at regional level

\begin{tabular}{|c|c|c|c|c|c|c|}
\hline Region & $\begin{array}{l}\text { Household } \\
\text { FW (kg/ } \\
\text { year) }\end{array}$ & $\begin{array}{l}\text { Low } 95 \% \\
\text { (kg/ year) }\end{array}$ & $\begin{array}{l}\text { Up } 95 \% \\
\text { (kg/year) }\end{array}$ & $\begin{array}{l}\text { Total FW } \\
\text { (tons/year) }\end{array}$ & $\begin{array}{l}\text { Low } \\
95 \% \\
\text { (tons/ } \\
\text { year) }\end{array}$ & $\begin{array}{l}\text { Up } 95 \% \\
\text { (tons/ } \\
\text { year) }\end{array}$ \\
\hline Budapest & 99.32 & 57.20 & 112.84 & 129,891 & 74,806 & 147,572 \\
\hline $\begin{array}{l}\text { Southern } \\
\text { Great Plain }\end{array}$ & 98.28 & 56.68 & 112.06 & 54,811 & 31,610 & 62,496 \\
\hline Pest & 97.76 & 56.51 & 111.28 & 49,183 & 28,429 & 55,985 \\
\hline $\begin{array}{l}\text { Western } \\
\text { Transdanubia }\end{array}$ & 97.50 & 56.16 & 111.28 & 39,449 & 22,722 & 45,024 \\
\hline Hungary & 97.24 & 56.16 & 111.02 & 401,737 & 232,019 & 458,668 \\
\hline
\end{tabular}




\begin{tabular}{llrr|rrr|}
$\begin{array}{l}\text { Central } \\
\text { Transdanubia }\end{array}$ & 97.24 & 55.99 & 110.76 & 42,659 & 24,561 & 48,590 \\
$\begin{array}{l}\text { Northern } \\
\text { Hungary }\end{array}$ & 96.20 & 55.29 & 110.24 & 44,733 & 25,711 & 51,262 \\
$\begin{array}{l}\text { Northern } \\
\text { Great Plain }\end{array}$ & 95.94 & 55.12 & 109.46 & 55,751 & 32,030 & 63,607 \\
\hline Hungary & 97.24 & 56.16 & 111.02 & 401,737 & 232,019 & 458,668 \\
\hline
\end{tabular}

Note: differences among the national values estimation and the sum of single regional values are due to computational approximations.

Source: REFRESH Road Map

The predicted food waste for Hungary, considering the actual regional values for GDP per capita and higher education level amounts to $\mathbf{9 7 . 2 4} \mathrm{kg}$ per household and an overall total of almost $\mathbf{4 0 1 , 7 3 7}$ tons per year.

At the regional level the lowest estimated values of food waste are registered in Northern Great Plain, with an average household FW of $\mathbf{9 5 . 9 5}$ kg per year, while the highest are recorded in Budapest, with a value of $\mathbf{9 9 . 3 2} \mathbf{k g}$ per year. 


\section{Ireland}

Hungary is divided in 3 regions (NUTS 2): Northern and Western Ireland, Southern Ireland, and Eastern and Midland.

According to 2017 Eurostat data, the population amounts to 4,784,383 The Gross Domestic Product (GDP) per capita on purchasing power parity is 53,500 euro, with relevant regional differences ranging from $\mathbf{2 4 , 7 0 0}$ euro per capita of Northern and Western Ireland area to 65,000 euro per capita of the Southern Ireland region. There are 1,795,000 households, with an average size of $\mathbf{2 . 6}$ persons.

The average employment rate is $\mathbf{6 7 . 7 \%}$, while the level of tertiary education is $\mathbf{4 6 . 9 \%}$. Table 16-1 summarizes the baseline values based on Eurostat data.

Table 16-1: Ireland - parameters for FW estimation at regional level

\begin{tabular}{|c|c|c|c|c|c|}
\hline Region & $\begin{array}{l}\text { GDP PPP } \\
\text { (EUR) }\end{array}$ & $\begin{array}{l}\text { Tertiary } \\
\text { education } \\
\text { level }\end{array}$ & $\begin{array}{l}\text { Median } \\
\text { age }\end{array}$ & Population & $\begin{array}{l}N^{\circ} \text { of } \\
\text { households }\end{array}$ \\
\hline $\begin{array}{l}\text { Northern and } \\
\text { Western Ireland }\end{array}$ & 24,700 & $41.2 \%$ & 38.3 & 848,383 & 323,300 \\
\hline $\begin{array}{l}\text { Southern } \\
\text { Ireland }\end{array}$ & 65,000 & $42.5 \%$ & 38.0 & $1,591,718$ & 600,000 \\
\hline $\begin{array}{l}\text { Eastern and } \\
\text { Midland }\end{array}$ & 55,700 & $51.7 \%$ & 35.9 & $2,344,282$ & 871,800 \\
\hline Hungary & 53,300 & $46.9 \%$ & 36.9 & $4,784,383$ & $1,795,000$ \\
\hline
\end{tabular}

Source: author's elaboration on Eurostat data

Figure 13 and

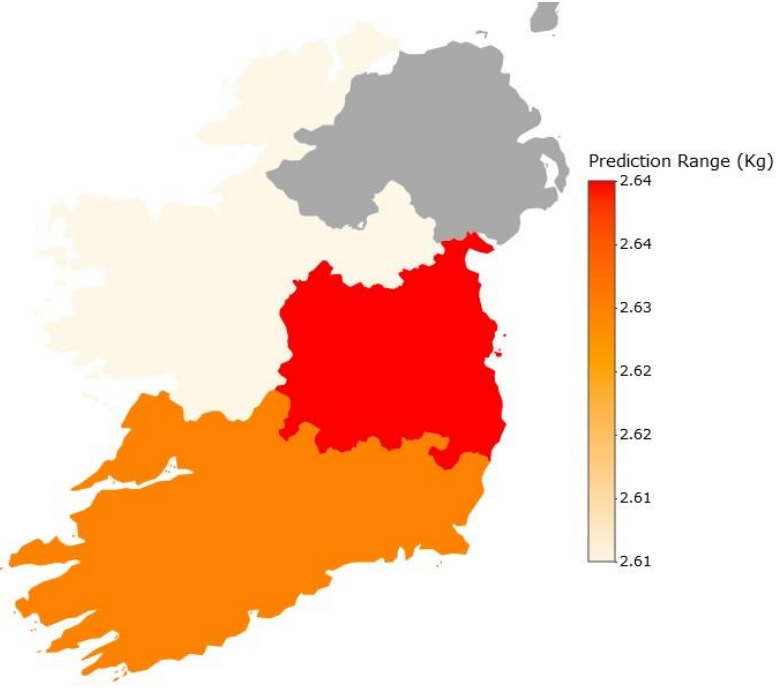

Table 16-2 summarize the food waste estimations for the country, both at the regional and national level, as developed by on basis of simulations run with the REFRESH Road Map (Stewart et al, 2019). 
Figure 13: estimated FW per household in Irish regions

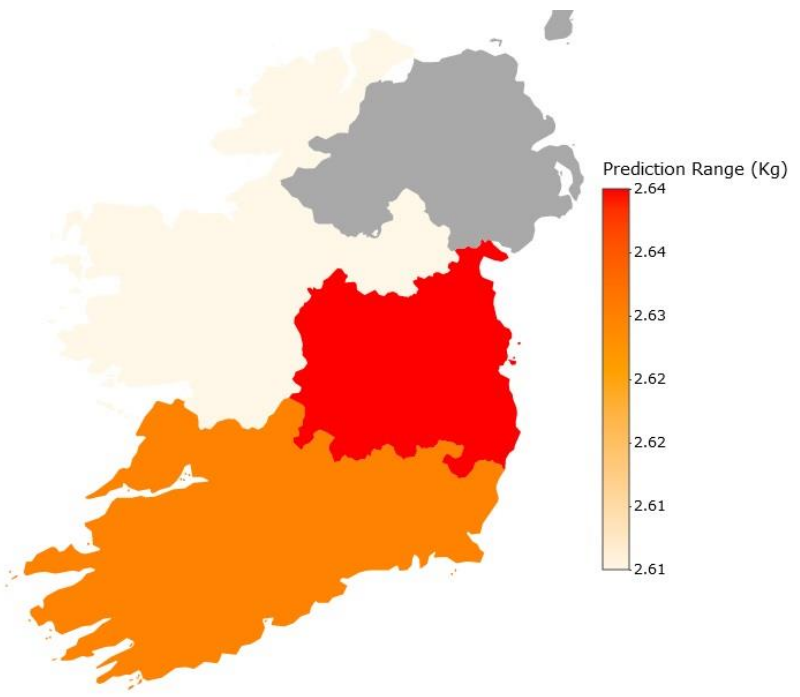

Table 16-2: Ireland - FW estimation at regional level

\begin{tabular}{|c|c|c|c|c|c|c|}
\hline Region & $\begin{array}{l}\text { Household } \\
\text { FW (kg/ } \\
\text { year) }\end{array}$ & $\begin{array}{l}\text { Low } 95 \% \\
\text { (kg/ year) }\end{array}$ & $\begin{array}{l}\text { Up } 95 \% \\
\text { (kg/year) }\end{array}$ & $\begin{array}{l}\text { Total FW } \\
\text { (tons/year) }\end{array}$ & $\begin{array}{l}\text { Low } \\
95 \% \\
\text { (tons/ } \\
\text { year) }\end{array}$ & $\begin{array}{l}\text { Up 95\% } \\
\text { (tons/ } \\
\text { year) }\end{array}$ \\
\hline $\begin{array}{l}\text { Eastern and } \\
\text { Midland }\end{array}$ & 132.08 & 79.04 & 145.6 & 115,147 & 68,907 & 126,934 \\
\hline $\begin{array}{l}\text { Southern } \\
\text { Ireland }\end{array}$ & 130.52 & 78.00 & 144.04 & 78,312 & 46,800 & 86,424 \\
\hline $\begin{array}{l}\text { Northern and } \\
\text { Western } \\
\text { Ireland }\end{array}$ & 130.00 & 78.00 & 144.04 & 42,029 & 25,217 & 46,568 \\
\hline Ireland & 131.04 & 78.52 & 144.82 & 235,217 & 140,943 & 259,952 \\
\hline
\end{tabular}

Note: differences among the national values estimation and the sum of single regional values are due to computational approximations.

Source: REFRESH Road Map

The predicted food waste for Ireland, considering the actual regional values for GDP per capita and higher education level amounts to $131.04 \mathrm{~kg}$ per household and an overall total of almost $\mathbf{2 3 5 , 2 1 7}$ tons per year.

At the regional level the lowest estimated values of food waste are registered in Northern and Western Ireland, with an average household FW of $\mathbf{1 3 0} \mathrm{kg}$ per year, while the highest are recorded in Eastern and Midland, with a value of $\mathbf{1 3 2 . 0 8} \mathbf{k g}$ per year. 


\section{Italy}

Italy is divided in 21 regions (NUTS 2): Piedmont, Valle d'Aosta, Liguria, Lombardy, Abruzzo, Molise, Campania, Puglia, Basilicata, Calabria, Sicily, Sardinia, South Tyrol, Trento, Veneto, Friuli-Venezia Giulia, Emilia-Romagna, Tuscany, Umbria, Marche, and Lazio.

According to 2017 Eurostat data, the population amounts to $\mathbf{6 0 , 5 8 9 , 4 4 5}$, The Gross Domestic Product (GDP) per capita on purchasing power parity is $\mathbf{2 8 , 4 0 0}$ euro, with relevant regional differences ranging from 17,100 euro per capita of Calabria area to $\mathbf{4 2 , 2 0 0}$ euro per capita of the South Tyrol region.

There are $\mathbf{2 5 , 8 6 4 , 5 0 0}$ households, with an average size of $\mathbf{2 . 3}$ persons.

The average employment rate is $\mathbf{5 8 \%}$, while the level of tertiary education is $\mathbf{1 9 . 3 \%}$. Table 17-1 summarizes the baseline values based on Eurostat data.

Table 17-1: Italy - parameters for FW estimation at regional level

\begin{tabular}{|c|c|c|c|c|c|}
\hline Region & $\begin{array}{l}\text { GDP } \\
\text { PPP } \\
\text { (EUR) }\end{array}$ & $\begin{array}{l}\text { Tertiary } \\
\text { education level }\end{array}$ & $\begin{array}{l}\text { Median } \\
\text { age }\end{array}$ & Population & $\begin{array}{l}N^{\circ} \text { of } \\
\text { households }\end{array}$ \\
\hline Piedmont & 30,100 & $19.3 \%$ & 47.9 & $4,392,526$ & $2,006,400$ \\
\hline Valle d'Aosta & 35,000 & $18.8 \%$ & 47.1 & 126,883 & 60,900 \\
\hline Liguria & 31,400 & $22.0 \%$ & 50.3 & $1,565,307$ & 770,700 \\
\hline Lombardia & 37,800 & $21.2 \%$ & 45.9 & $10,019,166$ & $4,430,800$ \\
\hline Abruzzo & 24,600 & $19.3 \%$ & 46.6 & $1,322,247$ & 554,500 \\
\hline Molise & 19,700 & $19.7 \%$ & 47.2 & 310,449 & 130,600 \\
\hline Campania & 18,200 & $15.5 \%$ & 42.5 & $5,839,084$ & $2,162,600$ \\
\hline Puglia & 18,300 & $14.8 \%$ & 44.7 & $4,063,888$ & $1,588,400$ \\
\hline Baslicata & 21,000 & $15.9 \%$ & 46.1 & 570,365 & 232,900 \\
\hline Calabria & 17,100 & $15.1 \%$ & 44.4 & $1,965,128$ & 801,800 \\
\hline Sicily & 17,400 & $14.0 \%$ & 44.0 & $5,056,641$ & $2,020,100$ \\
\hline Sardinia & 20,500 & $16.1 \%$ & 47.2 & $1,653,135$ & 720,900 \\
\hline South Tirol & 42,200 & $17.8 \%$ & 43.4 & 524,256 & 218,700 \\
\hline Trento & 35,900 & $21.3 \%$ & 45.4 & 538,604 & 233,500 \\
\hline Veneto & 32,900 & $18.8 \%$ & 46.4 & $4,907,529$ & $2,063,200$ \\
\hline $\begin{array}{l}\text { Friuli-Venezia } \\
\text { Giulia }\end{array}$ & 30,800 & $21.1 \%$ & 48.5 & $1,217,872$ & 559,200 \\
\hline
\end{tabular}




\begin{tabular}{lrrrrr|}
$\begin{array}{l}\text { Emilia- } \\
\text { Romagna }\end{array}$ & 35,200 & $22.0 \%$ & 46.9 & $4,448,841$ & $1,995,000$ \\
\hline Tuscany & 30,300 & $21.4 \%$ & 47.8 & $3,742,437$ & $1,646,000$ \\
\hline Umbria & 24,400 & $20.7 \%$ & 47.5 & 888,908 & 383,500 \\
\hline Marche & 26,700 & $20.5 \%$ & 47.1 & $1,538,055$ & 643,800 \\
\hline Lazio & 32,600 & $25.6 \%$ & 45.5 & $5,898,124$ & $2,641,200$ \\
\hline Italy & 28,400 & $19.3 \%$ & 45.9 & $60,589,445$ & $25,864,700$ \\
\hline
\end{tabular}

Source: author's elaboration on Eurostat data

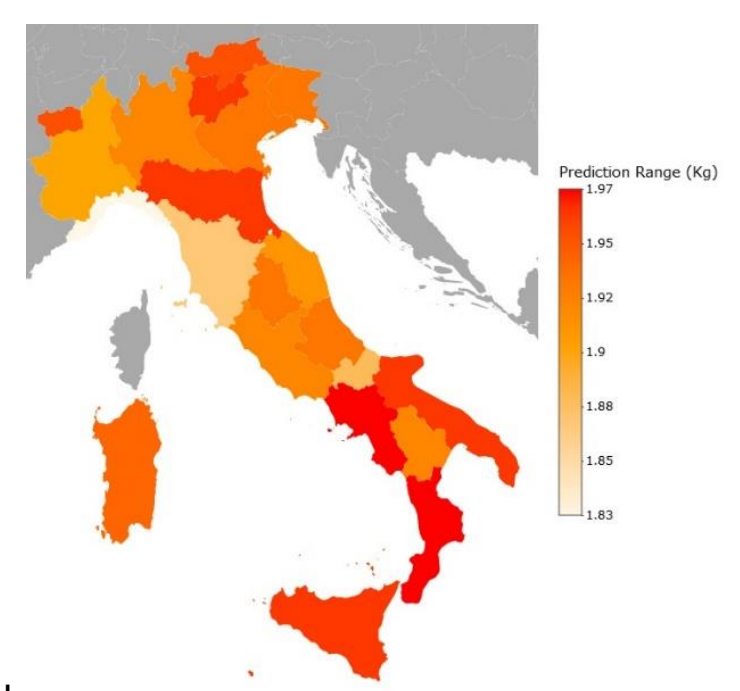

Figure 14 and

Table 17-2 summarize the food waste estimations for the country, both at the regional and national level, as developed by on basis of simulations run with the REFRESH Road Map (Stewart et al, 2019). 
Figure 14: estimated FW per household in Italian regions

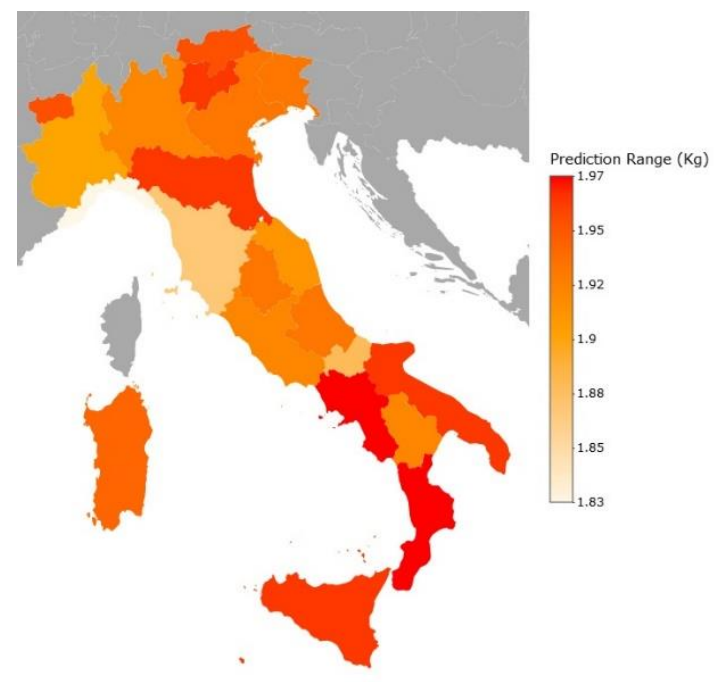

Table 17-2: Italy - FW estimation at regional level

\begin{tabular}{|c|c|c|c|c|c|c|}
\hline Region & $\begin{array}{l}\text { Household } \\
\text { FW (kg/ } \\
\text { year) }\end{array}$ & $\begin{array}{l}\text { Low } \\
95 \% \\
(\mathrm{~kg} / \\
\text { year) }\end{array}$ & $\begin{array}{l}\text { Up } 95 \% \\
\text { (kg/year) }\end{array}$ & $\begin{array}{l}\text { Total } F W \\
\text { (tons/year) }\end{array}$ & $\begin{array}{l}\text { Low 95\% } \\
\text { (tons/ } \\
\text { year) }\end{array}$ & $\begin{array}{l}\text { Up } 95 \% \\
\text { (tons/ } \\
\text { year) }\end{array}$ \\
\hline Campania & 96.98 & 55.81 & 110.76 & 209,729 & 120,702 & 239,530 \\
\hline Calabria & 96.72 & 55.47 & 110.24 & 77,550 & 44,473 & 88,390 \\
\hline Puglia & 96.20 & 55.12 & 109.72 & 152,804 & 87,553 & 174,279 \\
\hline Sicily & 96.20 & 55.12 & 109.98 & 194,334 & 111,348 & 222,171 \\
\hline Trento & 9620 & 55.29 & 109.72 & 22,463 & 12,911 & 25,620 \\
\hline $\begin{array}{l}\text { Emilia- } \\
\text { Romagna }\end{array}$ & 95.94 & 55.29 & 109.46 & 191,400 & 110,310 & 218,373 \\
\hline Valle d'Aosta & 95.42 & 54.77 & 108.94 & 5,811 & 3,336 & 6,634 \\
\hline Sardinia & 95.16 & 54.60 & 109.20 & 68,601 & 39,361 & 78,722 \\
\hline South Tirol & 95.16 & 54.60 & 108.68 & 20,811 & 11,941 & 23,768 \\
\hline Abruzzo & 94.64 & 54.25 & 108.16 & 52,478 & 30,083 & 59,975 \\
\hline Veneto & 94.64 & 54.08 & 108.16 & 195,261 & 111,578 & 223,156 \\
\hline $\begin{array}{l}\text { Friuli-Venezia } \\
\text { Giulia }\end{array}$ & 94.64 & 54.43 & 108.16 & 52,923 & 30,435 & 60,483 \\
\hline Umbria & 94.64 & 54.43 & 108.16 & 36,294 & 20,873 & 41,479 \\
\hline Lazio & 94.38 & 53.91 & 108.16 & 249,276 & 142,378 & 285,672 \\
\hline
\end{tabular}




\begin{tabular}{|c|c|c|c|c|c|c|}
\hline Lombardia & 94.12 & 54.08 & 107.64 & 417,027 & 239,618 & 476,931 \\
\hline Baslicata & 93.86 & 53.73 & 107.12 & 21,860 & 12,514 & 24,948 \\
\hline Marche & 93.60 & 53.39 & 107.12 & 60,260 & 34,370 & 68,964 \\
\hline Piedmont & 92.82 & 53.04 & 106.60 & 186,234 & 106,419 & 213,882 \\
\hline Molise & 92.04 & 52.69 & 105.82 & 12,020 & 6,882 & 13,820 \\
\hline Tuscany & 91.52 & 52.35 & 105.04 & 150,642 & 86,163 & 172,896 \\
\hline Liguria & 89.44 & 50.96 & 102.96 & 68,931 & 39,275 & 79,351 \\
\hline Italy & 94.64 & 54.08 & 108.16 & $2,447,835$ & $1,398,763$ & $2,797,526$ \\
\hline
\end{tabular}

Note: differences among the national values estimation and the sum of single regional values are due to computational approximations.

Source: REFRESH Road Map

The predicted food waste for Italy. Considering the actual regional values for GDP per capita and higher education level amounts to $\mathbf{9 4 . 6 4} \mathrm{kg}$ per household and an overall total of almost $\mathbf{2 , 4 7 7 , 8 3 5}$ tons per year.

At the regional level, the lowest estimated values of food waste are registered in Liguria. With an average household FW of $\mathbf{8 9 . 4 4} \mathrm{kg}$ per year. While the highest are recorded in Campania with a value of $\mathbf{9 6 . 9 8} \mathbf{k g}$ per year. 


\section{Lithuania}

Lithuania is divided in 2 regions (NUTS 2): Sostinès regionas and Vidurio ir vakaru. According to 2017 Eurostat data, the population amounts to $\mathbf{2 , 8 4 7 , 9 0 4}$ The Gross Domestic Product (GDP) per capita on purchasing power parity is $\mathbf{2 3 , 0 0 0}$ euro, $\mathbf{3 3}, \mathbf{0 0 0}$ euro per capita in Sostinès regionas area and 19,100 euro per capita in the Vidurio ir vakaru region.

There are 1,357,000 households, with an average size of $\mathbf{2 . 1}$ persons, and the number of households is, according to Eurostat data.

The average employment rate is $\mathbf{7 0 . 4 \%}$, while the level of tertiary education is 41.7\%. Table 18-1 summarizes the baseline values based on Eurostat data.

Table 18-1: Lithuania - parameters for FW estimation at regional level

\begin{tabular}{lrrrrr} 
Region & $\begin{array}{l}\text { GDP } \\
\text { PPP } \\
\text { (EUR) }\end{array}$ & \multicolumn{1}{l}{$\begin{array}{l}\text { Tertiary } \\
\text { education level }\end{array}$} & $\begin{array}{l}\text { Median } \\
\text { age }\end{array}$ & Population & $\begin{array}{l}N^{\circ} \text { of } \\
\text { households }\end{array}$ \\
\hline $\begin{array}{l}\text { Sostinès } \\
\text { regionas }\end{array}$ & 33,000 & $54.7 \%$ & 39.8 & 805,173 & 384,500 \\
$\begin{array}{l}\text { Vidurio ir } \\
\text { vakaru }\end{array}$ & 19,100 & $36.0 \%$ & 44.9 & $2,042,731$ & 972,500 \\
\hline Lithuania & 23,000 & $41.7 \%$ & 43.4 & $2,847,904$ & $1,357,000$
\end{tabular}

Source: author's elaboration on Eurostat data

Figure 15 and

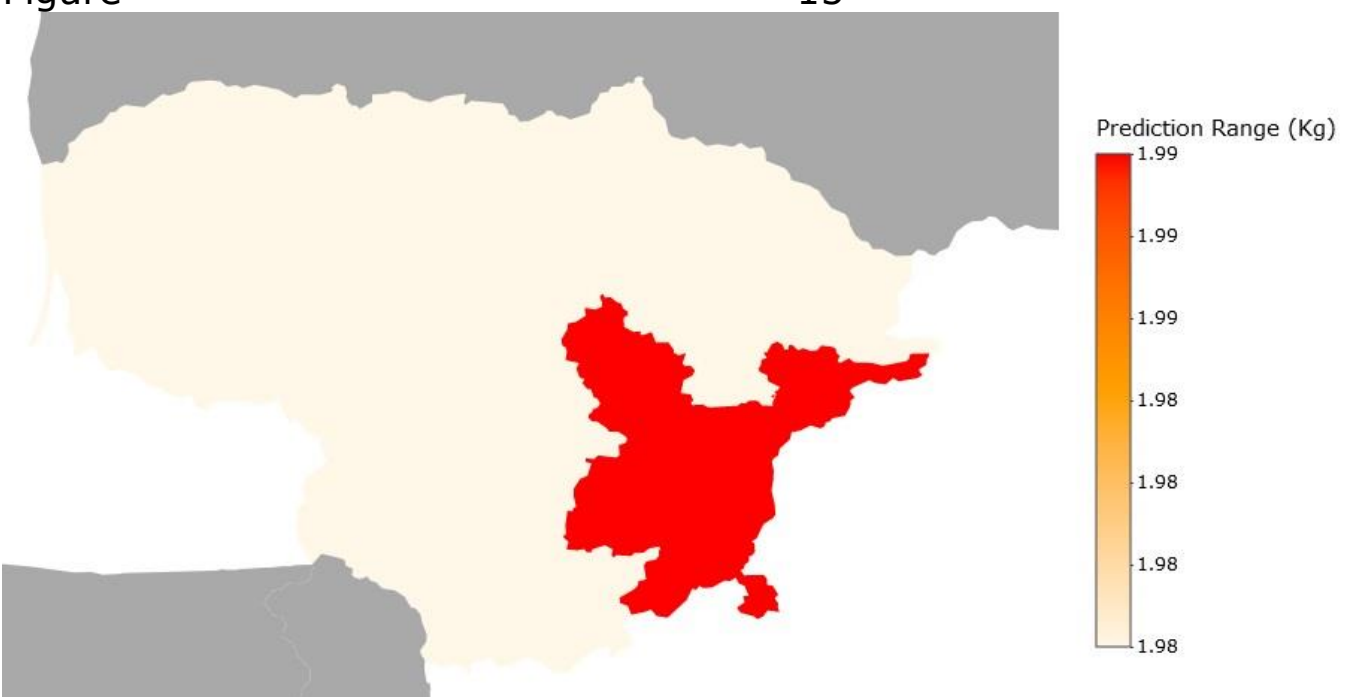

Table 18-2 summarize the food waste estimations for the country, both at the regional and national level, as developed by on basis of simulations run with the REFRESH Road Map (Stewart et al, 2019). 
Figure 15: estimated FW per household in Lithuanian regions

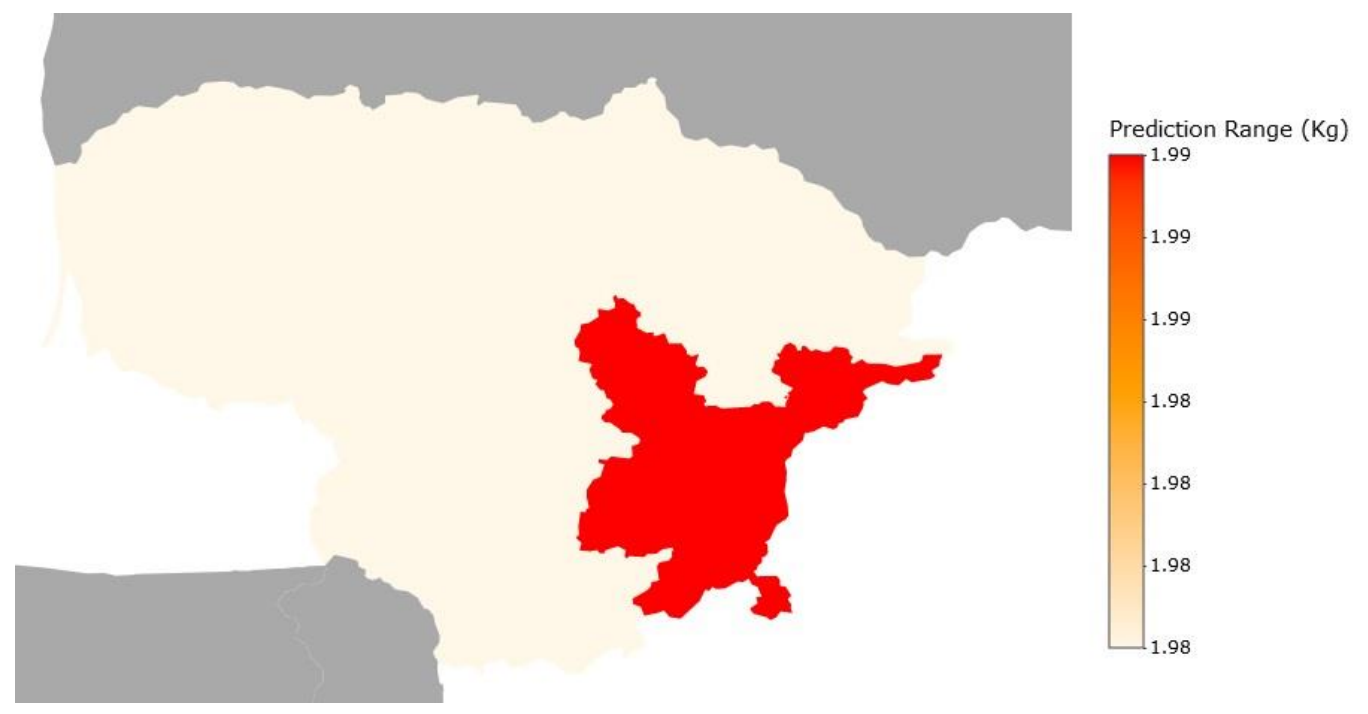

Table 18-2: Lithuania - FW estimation at regional level

\begin{tabular}{|c|c|c|c|c|c|c|}
\hline Region & $\begin{array}{l}\text { Household } \\
\text { FW (kg/ } \\
\text { year) }\end{array}$ & $\begin{array}{l}\text { Low } \\
95 \% \\
(\mathrm{~kg} / \\
\text { year) }\end{array}$ & $\begin{array}{l}\text { Up } 95 \% \\
\text { (kg/year) }\end{array}$ & $\begin{array}{l}\text { Total FW } \\
\text { (tons/year) }\end{array}$ & $\begin{array}{l}\text { Low } \\
95 \% \\
\text { (tons/ } \\
\text { year) }\end{array}$ & $\begin{array}{l}\text { Up } 95 \% \\
\text { (tons/ } \\
\text { year) }\end{array}$ \\
\hline $\begin{array}{l}\text { Sostinès } \\
\text { regionas }\end{array}$ & 98.28 & 56.68 & 111.8 & 37,789 & 21,793 & 42,987 \\
\hline $\begin{array}{l}\text { Vidurio ir } \\
\text { vakaru }\end{array}$ & 96.98 & 55.81 & 110.5 & 94,313 & 54,278 & 107,461 \\
\hline Lithuania & 97.76 & 56.33 & 111.28 & 132,660 & 76,444 & 151,007 \\
\hline
\end{tabular}

Note: differences among the national values estimation and the sum of single regional values are due to computational approximations.

Source: REFRESH Road Map

The predicted food waste for Lithuania. considering the actual regional values for GDP per capita and higher education level amounts to $\mathbf{9 7 . 7 6} \mathbf{k g}$ per household and an overall total of almost $\mathbf{1 3 2 , 6 6 0}$ tons per year.

At the regional level the lowest estimated values of food waste are registered in Vidurio ir vakaru. with an average household FW of $\mathbf{9 6 . 9 8} \mathrm{kg}$ per year. while the highest are recorded in Sostinès regions with a value of $\mathbf{9 8 . 2 8} \mathbf{~ k g}$ per year. 


\section{Luxembourg}

The whole Luxembourg territory is considered as a unique NUTS 2 Region.

According to 2017 Eurostat data, the population amounts to 590,667 The Gross Domestic Product (GDP) per capita on purchasing power parity is $\mathbf{7 4 , 5 0 0}$ euro.

There are $\mathbf{2 4 2 , 4 0 0}$ households with an average size of $\mathbf{2 . 4}$ persons.

The average employment rate is $\mathbf{6 6 . 3 \%}$, while the level of tertiary education is 44.1\%. Table 19-1 summarizes the baseline values based on Eurostat data.

Table 19-1: Luxembourg - parameters for FW estimation at regional level

\begin{tabular}{lllrrr} 
Region & $\begin{array}{l}\text { GDP } \\
\text { PPP } \\
\text { (EUR) }\end{array}$ & $\begin{array}{l}\text { Tertiary } \\
\text { education } \\
\text { level }\end{array}$ & $\begin{array}{l}\text { Median } \\
\text { age }\end{array}$ & Population & $\begin{array}{l}N^{\circ} \text { of } \\
\text { households }\end{array}$ \\
\hline Luxembourg & 74,500 & $44.1 \%$ & 39.4 & 590,667 & 242,400
\end{tabular}

Source: author's elaboration on Eurostat data

Table 19-2 summarizes the food waste estimations for the country as developed by on basis of simulations run with the REFRESH Road Map (Stewart et al, 2019),

Table 19-2: Luxembourg - FW estimation at regional level

\begin{tabular}{llrrr|rrr} 
Region & $\begin{array}{l}\text { Household } \\
\text { FW (kg/ } \\
\text { year) }\end{array}$ & $\begin{array}{l}\text { Low 95\% } \\
\text { (kg/ year) }\end{array}$ & $\begin{array}{l}\text { Up 95\% } \\
\text { (kg/year) }\end{array}$ & $\begin{array}{l}\text { Total FW } \\
\text { (tons/year) }\end{array}$ & $\begin{array}{l}\text { Low } \\
95 \% \\
\text { (tons/ } \\
\text { year) }\end{array}$ & $\begin{array}{l}\text { Up 95\% } \\
\text { (tons/ } \\
\text { year) }\end{array}$ \\
Luxembourg & 93.08 & 39.78 & 107.12 & 22,563 & 9,643 & 25,966
\end{tabular}

Note: differences among the national values estimation and the sum of single regional values are due to computational approximations.

Source: REFRESH Road Map

The predicted food waste for Luxembourg, considering the actual regional values for GDP per capita and higher education level amounts to $\mathbf{9 3 . 0 8} \mathrm{kg}$ per household and an overall total of almost $\mathbf{2 2 , 5 6 3}$ tons per year. 


\section{Latvia}

The whole Latvian territory is considered as a unique NUTS 2 Region.

According to 2017 Eurostat data, the population amounts to 1,950,116, according to 2017 Eurostat data. The gross domestic product (GDP) per capita on purchasing power parity is $\mathbf{1 9 , 6 0 0}$ euro.

There are $\mathbf{8 5 0}, \mathbf{1 0 0}$ households with an average size of $\mathbf{2 . 2}$ persons.

The average employment rate is $\mathbf{7 0 . 1 \%}$, while the level of tertiary education is $\mathbf{3 3 . 9} \%$. Table 20-1 summarizes the baseline values based on Eurostat data.

Table 20-1: Latvia - parameters for FW estimation at regional level

$\begin{array}{lllrrr}\text { Region } & \begin{array}{l}\text { GDP } \\ \text { PPP } \\ \text { (EUR) }\end{array} & \begin{array}{l}\text { Tertiary } \\ \text { education } \\ \text { level }\end{array} & \begin{array}{l}\text { Median } \\ \text { age }\end{array} & \text { Population } & \begin{array}{l}N^{\circ} \text { of } \\ \text { households }\end{array} \\ \text { Latvia } & 19,600 & 33.9 \% & 43.1 & 1,950,116 & 850,100\end{array}$

Source: author's elaboration on Eurostat data

Table 20-2 summarizes the food waste estimations for the country as developed by on basis of simulations run with the REFRESH Road Map (Stewart et al, 2019),

Table 20-2: Latvia - FW estimation at regional level

\begin{tabular}{|c|c|c|c|c|c|c|}
\hline Region & $\begin{array}{l}\text { Household } \\
\text { FW (kg/ } \\
\text { year) }\end{array}$ & $\begin{array}{l}\text { Low } 95 \% \\
\text { (kg/ year) }\end{array}$ & $\begin{array}{l}\text { Up } 95 \% \\
\text { (kg/year) }\end{array}$ & $\begin{array}{l}\text { Total FW } \\
\text { (tons/year) }\end{array}$ & $\begin{array}{l}\text { Low } \\
95 \% \\
\text { (tons/ } \\
\text { year) }\end{array}$ & $\begin{array}{l}\text { Up } 95 \% \\
\text { (tons/ } \\
\text { year) }\end{array}$ \\
\hline Latvia & 98.28 & 56.85 & 111.8 & 83,548 & 48,331 & 95,041 \\
\hline
\end{tabular}

Note: differences among the national values estimation and the sum of single regional values are due to computational approximations.

Source: REFRESH Road Map

The predicted food waste for Latvia, considering the actual regional values for GDP per capita and higher education level amounts to $\mathbf{9 8 . 2 8} \mathrm{kg}$ per household and an overall total of almost $\mathbf{8 3 , 5 4 8}$ tons per year. 


\section{$21 \quad$ Malta}

The whole Maltese territory is considered as a unique NUTS 2 Region.

According to 2017 Eurostat data, the population amounts to 460,297, according to 2017 Eurostat data. The gross domestic product (GDP) per capita on purchasing power parity is $\mathbf{2 8 , 7 0 0}$ euro.

There are $\mathbf{1 8 3 , 4 0 0}$ households with an average size of $\mathbf{2 . 5}$ persons

The average employment rate is $\mathbf{6 8 \%}$, while the level of tertiary education is $\mathbf{2 6 . 3 \%}$. Table 21-1 summarizes the baseline values based on Eurostat data.

Table 21-1: Malta - parameters for FW estimation at regional level

$\begin{array}{lllrrr}\text { Region } & \begin{array}{l}\text { GDP } \\ \text { PPP } \\ \text { (EUR) }\end{array} & \begin{array}{l}\text { Tertiary } \\ \text { education } \\ \text { level }\end{array} & \begin{array}{l}\text { Median } \\ \text { age }\end{array} & \text { Population } & \begin{array}{l}N^{\circ} \text { of } \\ \text { households }\end{array} \\ \text { Latvia } & 28,700 & 26.3 \% & 40.6 & 460,297 & 183,400\end{array}$

Source: author's elaboration on Eurostat data

Table 21-2 summarizes the food waste estimations for the country as developed by on basis of simulations run with the REFRESH Road Map (Stewart et al, 2019).

Table 21-2: Malta - FW estimation at regional level

\begin{tabular}{llrr|rrr|} 
Region & $\begin{array}{l}\text { Household } \\
\text { FW }(\mathrm{kg} / \\
\text { year) }\end{array}$ & $\begin{array}{l}\text { Low 95\% } \\
\text { (kg/ year) }\end{array}$ & $\begin{array}{l}\text { Up 95\% } \\
\text { (kg/year) }\end{array}$ & $\begin{array}{l}\text { Total FW } \\
\text { (tons/year) }\end{array}$ & $\begin{array}{l}\text { Low } \\
\text { (tons/ } \\
\text { year) }\end{array}$ & $\begin{array}{l}\text { Up 95\% } \\
\text { (tons/ } \\
\text { year) }\end{array}$ \\
Malta & 129.48 & 77.31 & 143.52 & 23,747 & 14,178 & 26,322
\end{tabular}

Note: differences among the national values estimation and the sum of single regional values are due to computational approximations,

Source: REFRESH Road Map

The predicted food waste for Malta, considering the actual regional values for GDP per capita and higher education level amounts to $\mathbf{1 2 9 . 4 8} \mathrm{kg}$ per household and an overall total of almost $\mathbf{2 3 , 7 4 7}$ tons per year. 


\section{The Netherlands}

The Netherlands territory is divided in 12 regions (NUTS 2): Groningen, Friesland, Drenthe, Overijssel, Gelderland, Flevoland, Utrecht, Noord-Holland, Zuid-Holland, Zeeland, Noord-Brabant, and Limburg.

According to 2017 Eurostat data, the population amounts to $\mathbf{1 7 , 0 8 1 , 5 0 7}$ The Gross Domestic Product (GDP) per capita on purchasing power parity is $\mathbf{3 7 , 7 0 0}$ euro, with some regional differences ranging from $\mathbf{2 5 , 8 0 0}$ euro per capita of Drenthe area to 49,300 euro per capita of the Noord-Holland region.

There are $\mathbf{7 , 8 1 9 , 0 0 0}$ households, with an average size of $\mathbf{2 . 2}$ persons.

The average employment rate is $\mathbf{7 5 . 8 \%}$, while the level of tertiary education is $\mathbf{3 8 . 3} \%$. Table 22-1 summarizes the baseline values based on Eurostat data.

Table 22-1: The Netherlands - parameters for FW estimation at regional level

\begin{tabular}{|c|c|c|c|c|c|}
\hline Region & $\begin{array}{l}\text { GDP } \\
\text { PPP } \\
\text { (EUR) }\end{array}$ & $\begin{array}{l}\text { Tertiary } \\
\text { education } \\
\text { level }\end{array}$ & $\begin{array}{l}\text { Median } \\
\text { age }\end{array}$ & Population & $\begin{array}{l}N^{\circ} \text { of } \\
\text { households }\end{array}$ \\
\hline Groningen & 35,900 & $36.2 \%$ & 41.9 & 583,581 & 292,600 \\
\hline Friesland & 26,000 & $31.8 \%$ & 44.4 & 646,874 & 298,400 \\
\hline Drenthe & 25,800 & $31.1 \%$ & 46.4 & 491,792 & 211,700 \\
\hline Overijssel & 31,400 & $33.4 \%$ & 42.1 & $1,147,687$ & 509,900 \\
\hline Gelderland & 31,800 & $35.3 \%$ & 43.6 & $2,047,901$ & 925,800 \\
\hline Flevoland & 28,300 & $30.2 \%$ & 38.4 & 407,818 & 166,800 \\
\hline Utrecht & 45,700 & $51.2 \%$ & 39.8 & $1,284,504$ & 586,000 \\
\hline Noord-Holland & 49,300 & $45.4 \%$ & 41.3 & $2,809,483$ & $1,318,100$ \\
\hline Zuid-Holland & 37,700 & $38.9 \%$ & 41.0 & $3,650,222$ & $1,683,300$ \\
\hline Zeeland & 30,100 & $29.1 \%$ & 46.1 & 381,568 & 175,800 \\
\hline Noord-Brabant & 38,100 & $36.0 \%$ & 43.7 & $2,512,531$ & $1,131,100$ \\
\hline Limburg & 33,400 & $32.2 \%$ & 47.3 & $1,117,546$ & 519,600 \\
\hline $\begin{array}{l}\text { The } \\
\text { Netherlands }\end{array}$ & 37,700 & $38.3 \%$ & 42.5 & $17,081,507$ & $7,819,000$ \\
\hline
\end{tabular}

Source: author's elaboration on Eurostat data

Figure 16 and Table 22-2 summarize the food waste estimations for the country, both at the regional and national level, as developed by on basis of simulations run with the REFRESH Road Map (Stewart et al, 2019). 
Figure 16: estimated FW per household in Dutch regions

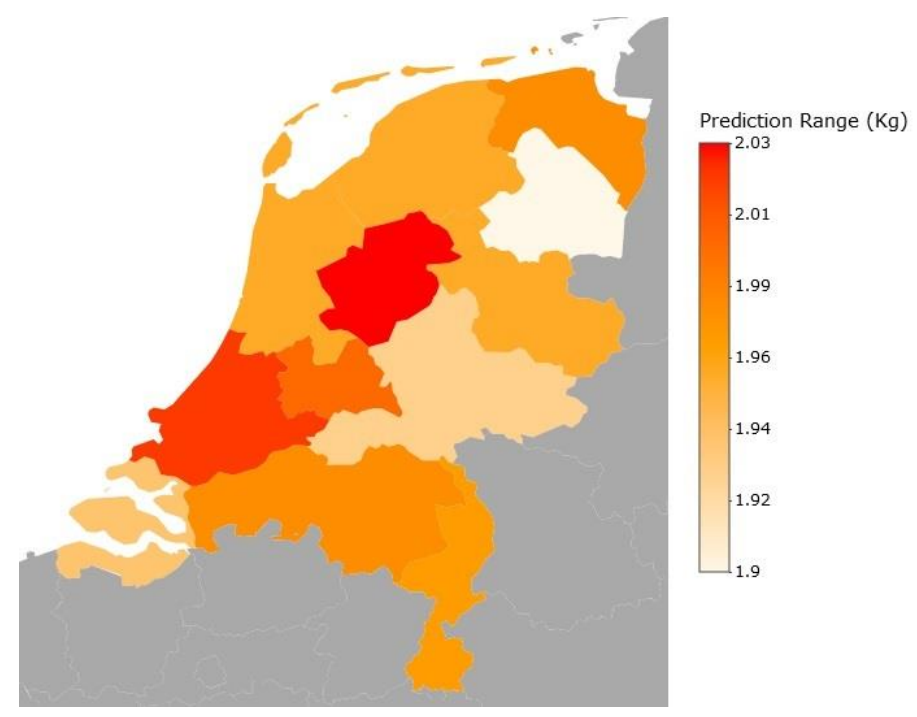

Table 22-2: the Netherlands - FW estimation at regional level

\begin{tabular}{|c|c|c|c|c|c|c|}
\hline Region & $\begin{array}{l}\text { Household } \\
\text { FW (kg/ } \\
\text { year) }\end{array}$ & $\begin{array}{l}\text { Low } 95 \% \\
\text { (kg/ year) }\end{array}$ & $\begin{array}{l}\text { Up } 95 \% \\
\text { (kg/year) }\end{array}$ & $\begin{array}{l}\text { Total } \quad F W \\
\text { (tons/year) }\end{array}$ & $\begin{array}{l}\text { Low } \\
95 \% \\
\text { (tons/ } \\
\text { year) }\end{array}$ & $\begin{array}{l}\text { Up 95\% } \\
\text { (tons/ } \\
\text { year) }\end{array}$ \\
\hline Flevoland & 99.84 & 57.55 & 113.36 & 16,653 & 9,599 & 18,908 \\
\hline Zuid-Holland & 99.32 & 57.20 & 113.1 & 167,185 & 96,285 & 190,381 \\
\hline Utrecht & 98.80 & 56.85 & 112.84 & 57,897 & 33,316 & 66,124 \\
\hline Groningen & 97.24 & 55.81 & 110.76 & 28,452 & 16,331 & 32,408 \\
\hline $\begin{array}{l}\text { Noord- } \\
\text { Brabant }\end{array}$ & 97.24 & 55.99 & 110.76 & 109,988 & 63,327 & 125,281 \\
\hline Limburg & 96.46 & 55.47 & 109.98 & 50,121 & 28,820 & 57,146 \\
\hline Friesland & 96.20 & 55.47 & 109.46 & 28,706 & 16,551 & 32,663 \\
\hline Overijssel & 96.20 & 55.12 & 109.72 & 49,052 & 28,106 & 55,946 \\
\hline Noord-Holland & 96.20 & 55.12 & 109.98 & 126,801 & 72,654 & 144,965 \\
\hline Zeeland & 95.16 & 54.43 & 108.68 & 16,729 & 9,568 & 19,106 \\
\hline Gelderland & 94.64 & 54.25 & 108.68 & 87,618 & 50,228 & 100,616 \\
\hline Drenthe & 93.08 & 53.39 & 106.6 & 19,705 & 11,302 & 22,567 \\
\hline $\begin{array}{l}\text { The } \\
\text { Netherlands }\end{array}$ & 96.72 & 55.64 & 110.24 & 756,254 & 435,049 & 861,967 \\
\hline
\end{tabular}


Note: differences among the national values estimation and the sum of single regional values are due to computational approximations.

Source: REFRESH Road Map

The predicted food waste for the Netherlands, considering the actual regional values for GDP per capita and higher education level amounts to $\mathbf{9 6 . 7 2} \mathbf{k g}$ per household and an overall total of almost 756,254 tons per year, At the regional level the lowest estimated values of food waste are registered in Drenthe, with an average household FW of $\mathbf{9 3 . 0 8} \mathbf{k g}$ per year, while the highest are recorded in Flevoland, with a value of $\mathbf{9 9 . 8 4} \mathbf{k g}$ per year. 


\section{Poland}

Poland territory is divided in 17 regions (NUTS 2): Małopolskie, Ślaskie, Wielkopolskie, Zachodniopomorskie, Lubuskie, Dolnośląskie, Opolskie, Kujawskopomorskie, Warmińsko-mazurskie, Pomorskie, Łódzkie, Świętokrzyskie, Lubelskie, Podkarpackie, Podlaskie, Warszawski stołeczny, and Mazowiecki regionalny.

According to 2017 Eurostat data, the population amounts to 37,972,964 The Gross Domestic Product (GDP) per capita on purchasing power parity is 20,500 euro, with relevant regional differences ranging from 14,100 euro per capita of Lubelskie area to $\mathbf{4 4 , 9 0 0}$ euro per capita of the Warszawski stołeczny region.

There are 14,465,800 households, with an average size of $\mathbf{2 . 6}$ persons.

The average employment rate is $\mathbf{6 6 . 1 \%}$, while the level of tertiary education is $\mathbf{3 0 . 9} \%$. Table 23-1 summarizes the baseline values based on Eurostat data.

Table 23-1: Poland - parameters for FW estimation at regional level

\begin{tabular}{|c|c|c|c|c|c|}
\hline Region & $\begin{array}{l}\text { GDP } \\
\text { PPP } \\
\text { (EUR) }\end{array}$ & $\begin{array}{l}\text { Tertiary } \\
\text { education } \\
\text { level }\end{array}$ & $\begin{array}{l}\text { Median } \\
\text { age }\end{array}$ & Population & $\begin{array}{l}N^{\circ} \text { of } \\
\text { households }\end{array}$ \\
\hline Małopolskie & 18,700 & $33.0 \%$ & 41.9 & $3,339,803$ & $1,196,300$ \\
\hline Śląskie & 21,200 & $29.7 \%$ & 39.0 & $4,510,528$ & $1,838,900$ \\
\hline Wielkopolskie & 22,400 & $26.5 \%$ & 41.7 & $3,457,473$ & $1,245,000$ \\
\hline Zachodniopomorskie & 17,100 & $28.6 \%$ & 39.0 & $1,681,246$ & 667,000 \\
\hline Lubuskie & 16,900 & $24.8 \%$ & 40.9 & $1,004,892$ & 371,500 \\
\hline Dolnośląskie & 22,700 & $31.7 \%$ & 40.1 & $2,866,218$ & $1,174,400$ \\
\hline Opolskie & 16,300 & $25.9 \%$ & 41.1 & 950,710 & 351,400 \\
\hline $\begin{array}{l}\text { Kujawsko- } \\
\text { pomorskie }\end{array}$ & 16,600 & $25.3 \%$ & 41.8 & $2,060,575$ & 772,000 \\
\hline $\begin{array}{l}\text { Warmińsko- } \\
\text { mazurskie }\end{array}$ & 14,400 & $23.6 \%$ & 40.2 & $1,410,641$ & 528,700 \\
\hline Pomorskie & 19,800 & $32.8 \%$ & 39.5 & $2,285,800$ & 869,700 \\
\hline Łódzkie & 19,200 & $29.0 \%$ & 39.1 & $2,471,620$ & 969,900 \\
\hline Świętokrzyskie & 14,600 & $28.9 \%$ & 42.0 & $1,237,518$ & 427,800 \\
\hline Lubelskie & 14,100 & $28.8 \%$ & 41.5 & $2,112,787$ & 759,600 \\
\hline Podkarpackie & 14,300 & $28.4 \%$ & 40.3 & $2,084,722$ & 664,600 \\
\hline Podlaskie & 14,700 & $32.3 \%$ & 39.2 & $1,156,947$ & 431,900 \\
\hline
\end{tabular}




\begin{tabular}{lccrrr|}
$\begin{array}{l}\text { Warszawski } \\
\text { stołeczny }\end{array}$ & 44,900 & $57.4 \%$ & 40.5 & $3,002,278$ & $1,297,200$ \\
\hline $\begin{array}{l}\text { Mazowiecki } \\
\text { regionalny }\end{array}$ & 17,500 & $23.6 \%$ & 40.3 & $2,339,206$ & 900,000 \\
\hline $\begin{array}{l}\text { Poland } \\
\text { N }\end{array}$ & 20,500 & $30.9 \%$ & 40.3 & $37,972,964$ & $14,465,800$ \\
\hline
\end{tabular}

Source: author's elaboration on Eurostat data

Figure 17 and

Table 23-2 summarize the food waste estimations for the country, both at the regional and national level, as developed by on basis of simulations run with the REFRESH Road Map (Stewart et al, 2019). 
Figure 17: estimated FW per household in Polish regions

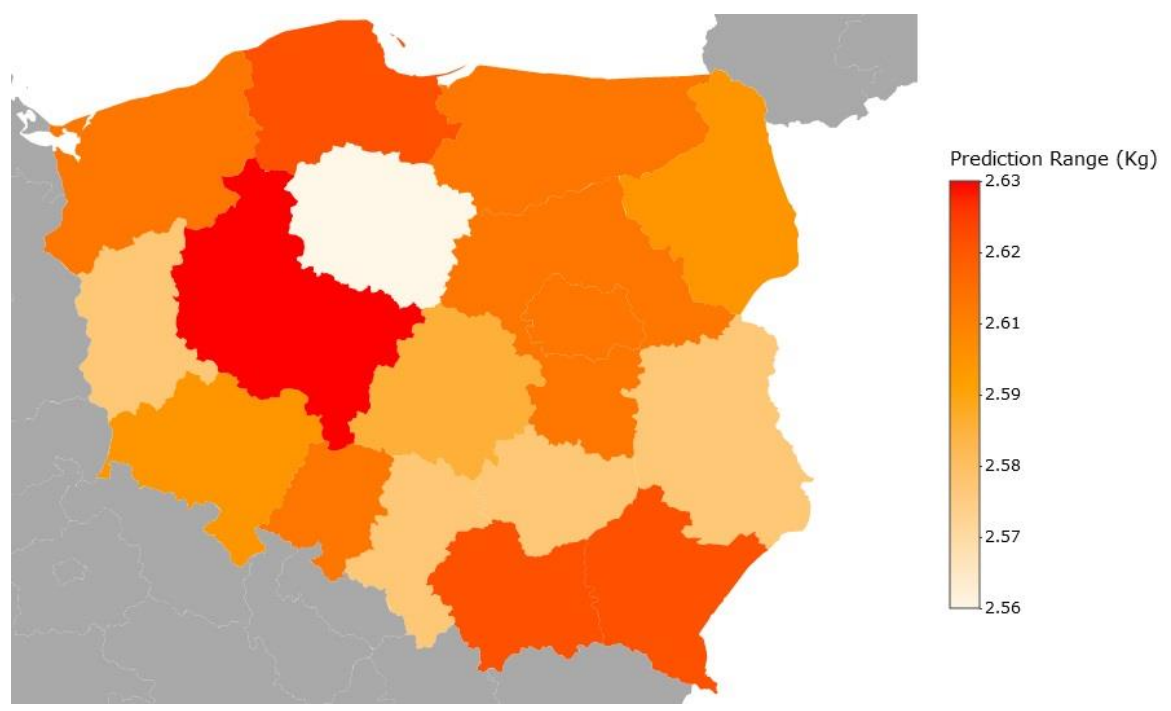

Table 23-2: Poland - FW estimation at regional level

\begin{tabular}{|c|c|c|c|c|c|c|}
\hline Region & $\begin{array}{l}\text { Household } \\
\text { FW (kg/ } \\
\text { year) }\end{array}$ & $\begin{array}{l}\text { Low } \\
95 \% \\
(\mathrm{~kg} / \\
\text { year) }\end{array}$ & $\begin{array}{l}\text { Up } 95 \% \\
\text { (kg/year) }\end{array}$ & $\begin{array}{l}\text { Total FW } \\
\text { (tons/year) }\end{array}$ & $\begin{array}{l}\text { Low 95\% } \\
\text { (tons/ } \\
\text { year) }\end{array}$ & $\begin{array}{l}\text { Up } 95 \% \\
\text { (tons/ } \\
\text { year) }\end{array}$ \\
\hline Wielkopolskie & 131.04 & 78.35 & 144.56 & 163,145 & 97,542 & 179,977 \\
\hline $\begin{array}{l}\text { Warszawski } \\
\text { stołeczny }\end{array}$ & 130.78 & 78.17 & 144.56 & 169,648 & 101,406 & 187,523 \\
\hline Małopolskie & 130.52 & 78.00 & 144.04 & 156,141 & 93,311 & 172,315 \\
\hline Pomorskie & 130.52 & 78.00 & 144.04 & 113,513 & 67,837 & 125,272 \\
\hline Podkarpackie & 130.52 & 78.00 & 144.04 & 86,744 & 51,839 & 95,729 \\
\hline Zachodniopomorskie & 130.00 & 77.65 & 143.52 & 86,710 & 51,795 & 95,728 \\
\hline $\begin{array}{l}\text { Mazowiecki } \\
\text { regionalny }\end{array}$ & 130.00 & 77.65 & 143.52 & 117,000 & 69,888 & 129,168 \\
\hline Opolskie & 129.74 & 77.48 & 143.78 & 45,591 & 27,226 & 50,524 \\
\hline $\begin{array}{l}\text { Warmińsko- } \\
\text { mazurskie }\end{array}$ & 129.74 & 77.48 & 143.52 & 68,594 & 40,964 & 75,879 \\
\hline Podlaskie & 129.48 & 77.65 & 143.00 & 55,922 & 33,538 & 61,762 \\
\hline Dolnośląskie & 129.22 & 77.31 & 142.48 & 151,756 & 90,789 & 167,329 \\
\hline Łódzkie & 128.96 & 76.96 & 142.48 & 125,078 & 74,644 & 138,191 \\
\hline
\end{tabular}


Note: differences among the national values estimation and the sum of single regional values are due to computational approximations.

Source: REFRESH Road Map

The predicted food waste for Poland, considering the actual regional values for GDP per capita and higher education level amounts to $\mathbf{1 2 9 . 4 8} \mathrm{kg}$ per household and an overall total of almost $\mathbf{1 , 8 7 3 , 0 3 2}$ tons per year.

At the regional level, the lowest estimated values of food waste are registered in Kujawsko-pomorskie, with an average household FW of $\mathbf{1 2 7 . 1 4} \mathrm{kg}$ per year, while the highest are recorded in Wielkopolskie, with a value of $\mathbf{1 3 1 . 0 4} \mathrm{kg}$ per year. 


\section{Portugal}

Portugal territory is divided in 7 regions (NUTS 2): Norte, Algarve, Centro, Área Metropolitana de Lisboa, Alentejo, Região Autónoma dos Açores, and Região Autónoma da Madeira.

According to 2017 Eurostat data, the population amounts to $\mathbf{1 0 , 3 0 9 , 5 7 3}$ The Gross Domestic Product (GDP) per capita on purchasing power parity is 22,600 euro, with some regional differences ranging from 19,100 euro per capita of Norte area to 29,600 euro per capita of the Área Metropolitana de Lisboa region.

There are $\mathbf{4 , 1 0 2 , 7 0 0 ~ h o u s e h o l d s , ~ w i t h ~ a n ~ a v e r a g e ~ s i z e ~ o f ~} \mathbf{2 . 5}$ persons.

The average employment rate is $\mathbf{6 7 . 8 \%}$, while the level of tertiary education is $\mathbf{2 5 \%}$. Table 24-1 summarizes the baseline values based on Eurostat data.

Table 24-1: Portugal - parameters for FW estimation at regional level

\begin{tabular}{|c|c|c|c|c|c|}
\hline Region & $\begin{array}{l}\text { GDP } \\
\text { PPP } \\
\text { (EUR) }\end{array}$ & $\begin{array}{l}\text { Tertiary } \\
\text { education } \\
\text { level }\end{array}$ & $\begin{array}{l}\text { Median } \\
\text { age }\end{array}$ & Population & $\begin{array}{l}N^{\circ} \text { of } \\
\text { households }\end{array}$ \\
\hline Norte & 19,100 & $21.8 \%$ & 44.3 & $3,584,575$ & $1,350,600$ \\
\hline Algarve & 24,400 & $22.4 \%$ & 43.7 & 441,469 & 182,400 \\
\hline Centro (PT) & 19,600 & $24.2 \%$ & 46.4 & $2,243,934$ & 914,600 \\
\hline $\begin{array}{l}\text { Área } \\
\text { Metropolitana } \\
\text { de Lisboa }\end{array}$ & 29,600 & $32.8 \%$ & 43.3 & $2,821,349$ & $1,173,900$ \\
\hline Alentejo & 21,300 & $20.2 \%$ & 46.9 & 718,087 & 305,800 \\
\hline $\begin{array}{l}\text { Região } \\
\text { Autónoma dos } \\
\text { Açores }\end{array}$ & 20,200 & $15.2 \%$ & 38.7 & 245,283 & 82,400 \\
\hline $\begin{array}{l}\text { Região } \\
\text { Autónoma da } \\
\text { Madeira }\end{array}$ & 21,600 & $21.2 \%$ & 41.7 & 254,876 & 92,900 \\
\hline Portugal & 22,600 & $25.0 \%$ & 44.4 & $10,309,573$ & $4,102,700$ \\
\hline
\end{tabular}

Source: author's elaboration on Eurostat data

Figure 18 and Table 24-2 summarize the food waste estimations for the country, both at the regional and national level, as developed by on basis of simulations run with the REFRESH Road Map (Stewart et al, 2019). 
Figure 18: estimated FW per household in Portuguese regions

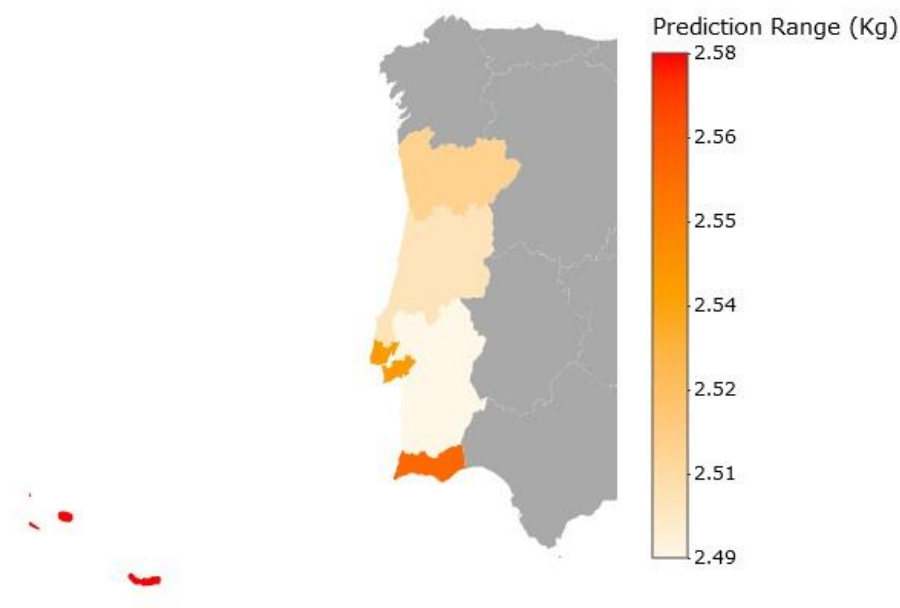

Table 24-2: Portugal - FW estimation at regional level

\begin{tabular}{|c|c|c|c|c|c|c|}
\hline Region & $\begin{array}{l}\text { Household } \\
\text { FW (kg/ } \\
\text { year) }\end{array}$ & $\begin{array}{l}\text { Low } 95 \% \\
\text { (kg/ year) }\end{array}$ & $\begin{array}{l}\text { Up } 95 \% \\
\text { (kg/year) }\end{array}$ & $\begin{array}{l}\text { Total FW } \\
\text { (tons/year) }\end{array}$ & $\begin{array}{l}\text { Low } \\
95 \% \\
\text { (tons/ } \\
\text { year) }\end{array}$ & $\begin{array}{l}\text { Up 95\% } \\
\text { (tons/ } \\
\text { year) }\end{array}$ \\
\hline $\begin{array}{l}\text { Região } \\
\text { Autónoma dos } \\
\text { Açores }\end{array}$ & 127.92 & 76.44 & 141.7 & 10,541 & 6,299 & 11,676 \\
\hline Algarve & 127.14 & 75.92 & 140.92 & 23,190 & 13,848 & 25,704 \\
\hline $\begin{array}{l}\text { Área } \\
\text { Metropolitana } \\
\text { de Lisboa }\end{array}$ & 126.88 & 75.75 & 140.4 & 148,944 & 88,919 & 164,816 \\
\hline $\begin{array}{l}\text { Região } \\
\text { Autónoma da } \\
\text { Madeira }\end{array}$ & 126.10 & 75.23 & 139.88 & 11,715 & 6,989 & 12,995 \\
\hline Norte & 124.54 & 74.19 & 138.32 & 168,204 & 100,197 & 186,815 \\
\hline Centro (PT) & 124.02 & 74.01 & 137.28 & 113,429 & 67,693 & 125,556 \\
\hline Alentejo & 123.24 & 73.32 & 137.02 & 37,687 & 22,421 & 41,901 \\
\hline Portugal & 125.84 & 75.05 & 139.36 & 516,284 & 307,921 & 571,752 \\
\hline
\end{tabular}

Note: differences among the national values estimation and the sum of single regional values are due to computational approximations.

Source: REFRESH Road Map 
The predicted food waste for Portugal, considering the actual regional values for GDP per capita and higher education level amounts to $\mathbf{1 2 5 . 8 4} \mathrm{kg}$ per household and an overall total of almost 516,284 tons per year,

At the regional level, the lowest estimated values of food waste are registered in Alentejo, with an average household FW of $\mathbf{1 2 3 . 2 4} \mathrm{kg}$ per year, while the highest are recorded in Região Autónoma dos Açores, with a value of $\mathbf{1 2 7 . 9 2}$ kg per year. 


\section{Romania}

Romania territory is divided in 8 regions (NUTS 2): Nord-Vest, Centru, Nord-Est, Sud-Est, Sud-Muntenia, București-Ilfov, Sud-Vest Oltenia, and Vest.

According to 2017 Eurostat data, the population amounts to $\mathbf{1 9 , 6 4 4 , 3 5 0}$ The Gross Domestic Product (GDP) per capita on purchasing power parity is 18,400 euro, with some regional differences ranging from 11,400 euro per capita of Nord-Est area to $\mathbf{4 2 , 4 0 0}$ euro per capita of the București-Ilfov region.

There are $\mathbf{7 , 4 8 2 , 4 0 0}$ households, with an average size of $\mathbf{2 . 6}$ persons.

The average employment rate is $\mathbf{6 3 . 9} \%$, while the level of tertiary education is $\mathbf{1 7 . 8} \%$. Table 25-1 summarizes the baseline values based on Eurostat data.

Table 25-1: Romania - parameters for FW estimation at regional level

\begin{tabular}{|c|c|c|c|c|c|}
\hline Region & $\begin{array}{l}\text { GDP } \\
\text { PPP } \\
\text { (EUR) }\end{array}$ & $\begin{array}{l}\text { Tertiary } \\
\text { education } \\
\text { level }\end{array}$ & $\begin{array}{l}\text { Median } \\
\text { age }\end{array}$ & Population & $\begin{array}{l}N^{\circ} \text { of } \\
\text { households }\end{array}$ \\
\hline Nord-Vest & 16,600 & $17.7 \%$ & 40.6 & $2,568,730$ & 952,500 \\
\hline Centru & 17,500 & $18.1 \%$ & 41.3 & $2,332,935$ & 874,600 \\
\hline Nord-Est & 11,400 & $12.7 \%$ & 40.3 & $3,239,612$ & $1,221,300$ \\
\hline Sud-Est & 15,500 & $13.1 \%$ & 43.0 & $2,446,734$ & 954,200 \\
\hline Sud-Muntenia & 14,800 & $12.7 \%$ & 43.5 & $3,003,349$ & $1,127,200$ \\
\hline București-Ilfov & 42,400 & $37.5 \%$ & 40.1 & $2,287,347$ & 903,000 \\
\hline $\begin{array}{l}\text { Sud-Vest } \\
\text { Oltenia }\end{array}$ & 13,400 & $14.7 \%$ & 43.9 & $1,973,140$ & 762,000 \\
\hline Vest & 19,600 & $15.7 \%$ & 42.1 & $1,792,503$ & 687,500 \\
\hline Romania & 18,400 & $17.8 \%$ & 41.8 & $19,644,350$ & $7,482,400$ \\
\hline
\end{tabular}

Source: author's elaboration on Eurostat data

Figure 19 and
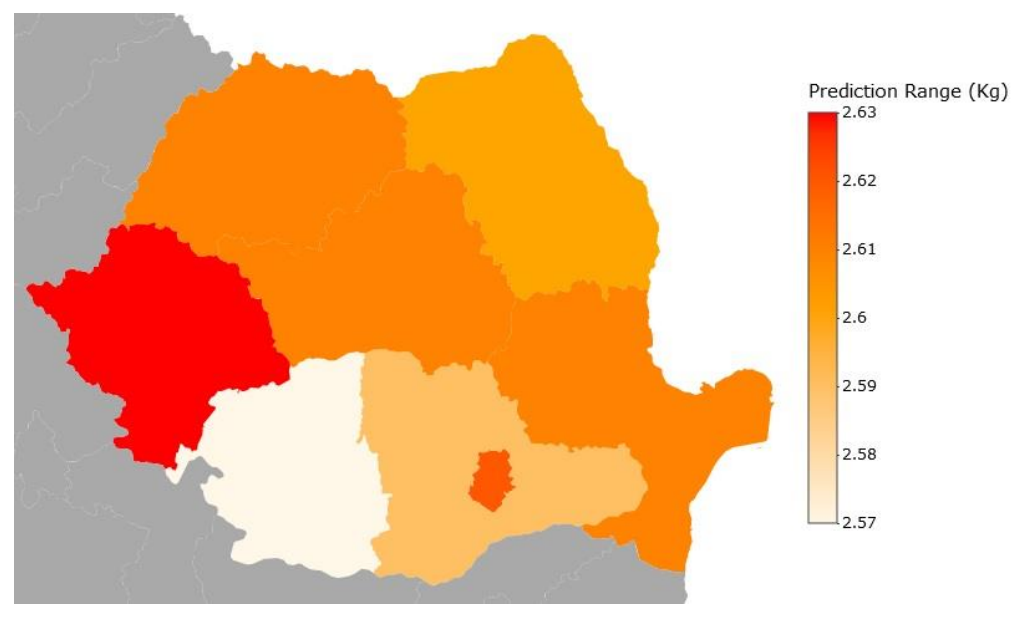
Table 25-2 summarize the food waste estimations for the country, both at the regional and national level, as developed by on basis of simulations run with the REFRESH Road Map (Stewart et al, 2019). 
Figure 19: estimated FW per household in Romanian regions

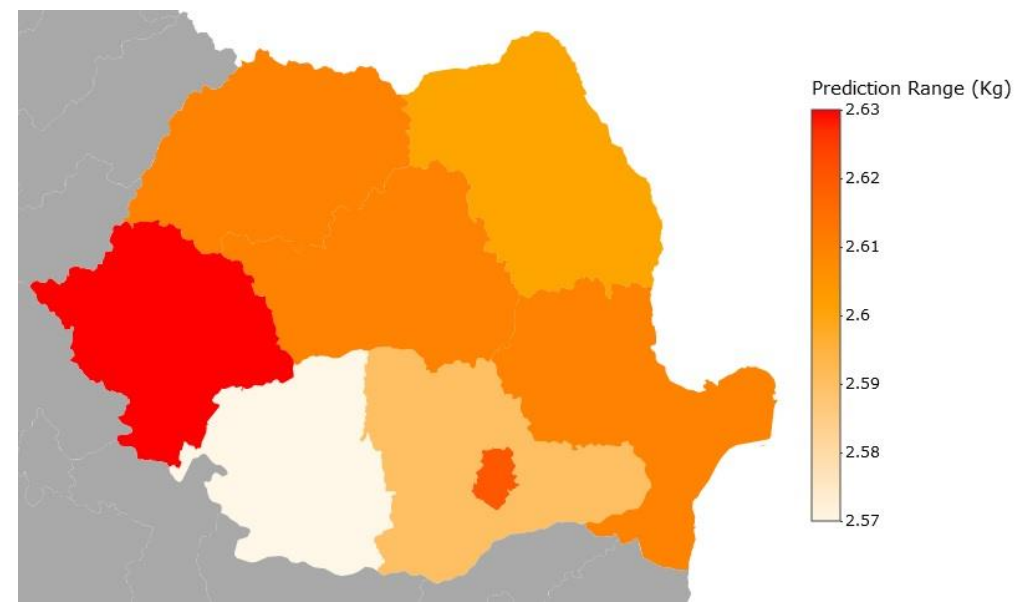

Table 25-2: Romania - FW estimation at regional level

\begin{tabular}{|c|c|c|c|c|c|c|}
\hline Region & $\begin{array}{l}\text { Household } \\
\text { FW (kg/ } \\
\text { year) }\end{array}$ & $\begin{array}{l}\text { Low } \\
95 \% \\
\text { (kg/ } \\
\text { year) }\end{array}$ & $\begin{array}{l}\text { Up } 95 \% \\
\text { (kg/year) }\end{array}$ & $\begin{array}{l}\text { Total FW } \\
\text { (tons/year) }\end{array}$ & $\begin{array}{l}\text { Low } \\
95 \% \\
\text { (tons/ } \\
\text { year) }\end{array}$ & $\begin{array}{l}\text { Up } 95 \% \\
\text { (tons/ } \\
\text { year) }\end{array}$ \\
\hline București-Ilfov & 123.76 & 77.48 & 143.26 & 111,755 & 69,964 & 129,364 \\
\hline Vest & 123.76 & 77.31 & 143 & 85,085 & 53,148 & 98,313 \\
\hline Centru & 122.72 & 76.61 & 141.96 & 107,331 & 67,006 & 124,158 \\
\hline Nord-Vest & 122.20 & 76.27 & 141.96 & 116,396 & 72,644 & 135,217 \\
\hline Sud-Est & 122.20 & 76.44 & 141.96 & 116,603 & 72,939 & 135,458 \\
\hline Nord-Est & 121.68 & 76.09 & 140.92 & 148,608 & 92,933 & 172,106 \\
\hline Sud-Muntenia & 121.16 & 75.92 & 140.92 & 136,572 & 85,577 & 158,845 \\
\hline $\begin{array}{l}\text { Sud-Vest } \\
\text { Oltenia }\end{array}$ & 120.12 & 75.23 & 139.36 & 91,531 & 57,323 & 106,192 \\
\hline Romania & 122.20 & 76.44 & 141.7 & 914,349 & 571,955 & $1,060,256$ \\
\hline
\end{tabular}

Note: differences among the national values estimation and the sum of single regional values are due to computational approximations.

Source: REFRESH Road Map

The predicted food waste for Romania, considering the actual regional values for GDP per capita and higher education level amounts to $\mathbf{1 2 2 . 2 0} \mathrm{kg}$ per household and an overall total of almost $\mathbf{9 1 4 . 3 4 9}$ tons per year,

At the regional level, the lowest estimated values of food waste are registered in Sud-Vest Oltenia, with an average household FW of $\mathbf{1 2 0 . 1 2} \mathrm{kg}$ per year, while the highest are recorded in București-Ilfov, with a value of $\mathbf{1 2 3 . 7 6} \mathrm{kg}$ per year. 


\section{Slovenia}

Slovenia is divided in 2 regions (NUTS 2): Vzhodna Slovenija and Zahodna Slovenija.

According to 2017 Eurostat data, the population amounts to $\mathbf{2 , 0 6 5 , 8 9 5}$ The Gross Domestic Product (GDP) per capita on purchasing power parity is 25,100 euro, $\mathbf{2 0 , 6 0 0}$ euro per capita in Vzhodna Slovenija area and $\mathbf{3 0 , 0 0 0}$ euro per capita in the Zahodna Slovenija region.

There are $\mathbf{8 8 1 , 1 0 0}$ households, with an average size of $\mathbf{2 . 3}$ persons.

The average employment rate is $\mathbf{7 1 . 6 \%}$, while the level of tertiary education is $\mathbf{4 4 . 5 \%}$. Table 26-1 summarizes the baseline values based on Eurostat data.

Table 26-1: Slovenia - parameters for FW estimation at regional level

\begin{tabular}{lrrrrr} 
Region & \multicolumn{1}{l}{$\begin{array}{l}\text { GDP } \\
\text { PPP } \\
\text { (EUR) }\end{array}$} & \multicolumn{1}{l}{$\begin{array}{l}\text { Tertiary } \\
\text { education level }\end{array}$} & $\begin{array}{l}\text { Median } \\
\text { age }\end{array}$ & Population & $\begin{array}{l}N^{\circ} \text { of } \\
\text { households }\end{array}$ \\
\hline $\begin{array}{l}\text { Vzhodna } \\
\text { Slovenija }\end{array}$ & 20,600 & $27.9 \%$ & 44.3 & $1,091,159$ & 465,000 \\
$\begin{array}{l}\text { Zahodna } \\
\text { Slovenija }\end{array}$ & 30,000 & $37.7 \%$ & 42.6 & 974,736 & 416,100 \\
\hline Slovenia & 25,100 & $32.5 \%$ & 43.5 & $2,065,895$ & 881,100
\end{tabular}

Source: author's elaboration on Eurostat data

Figure 20 and
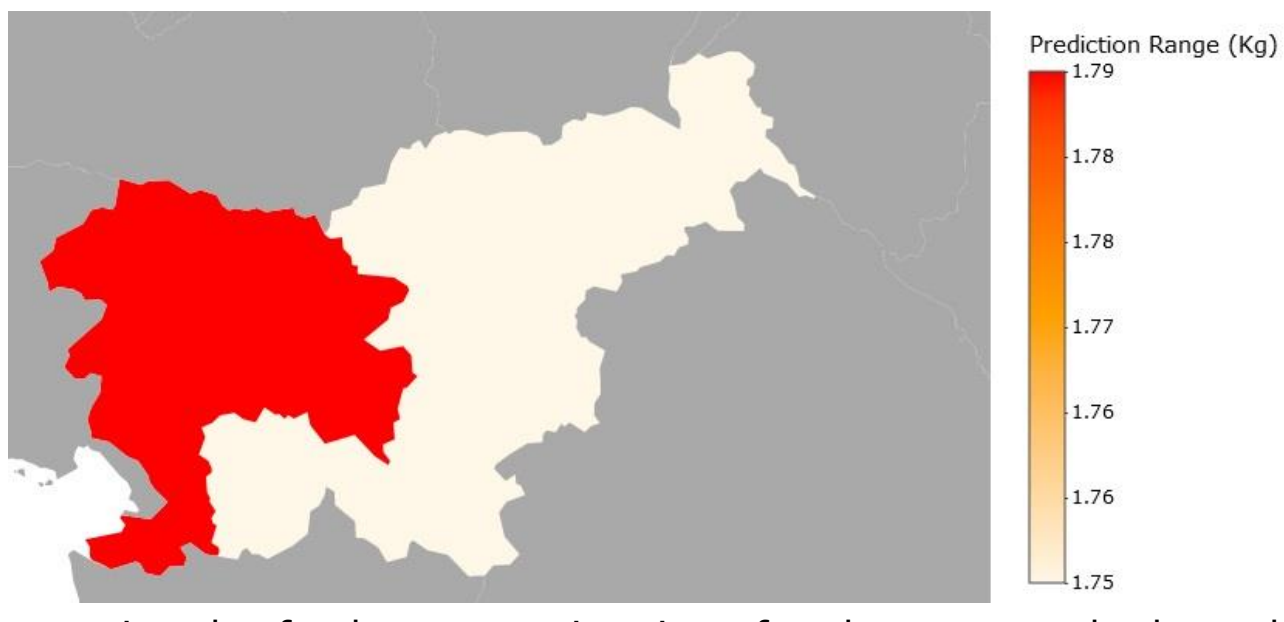

Table 26-2 summarize the food waste estimations for the country, both at the regional and national level, as developed by on basis of simulations run with the REFRESH Road Map (Stewart et al, 2019). 
Figure 20: estimated FW per household in Slovenia regions

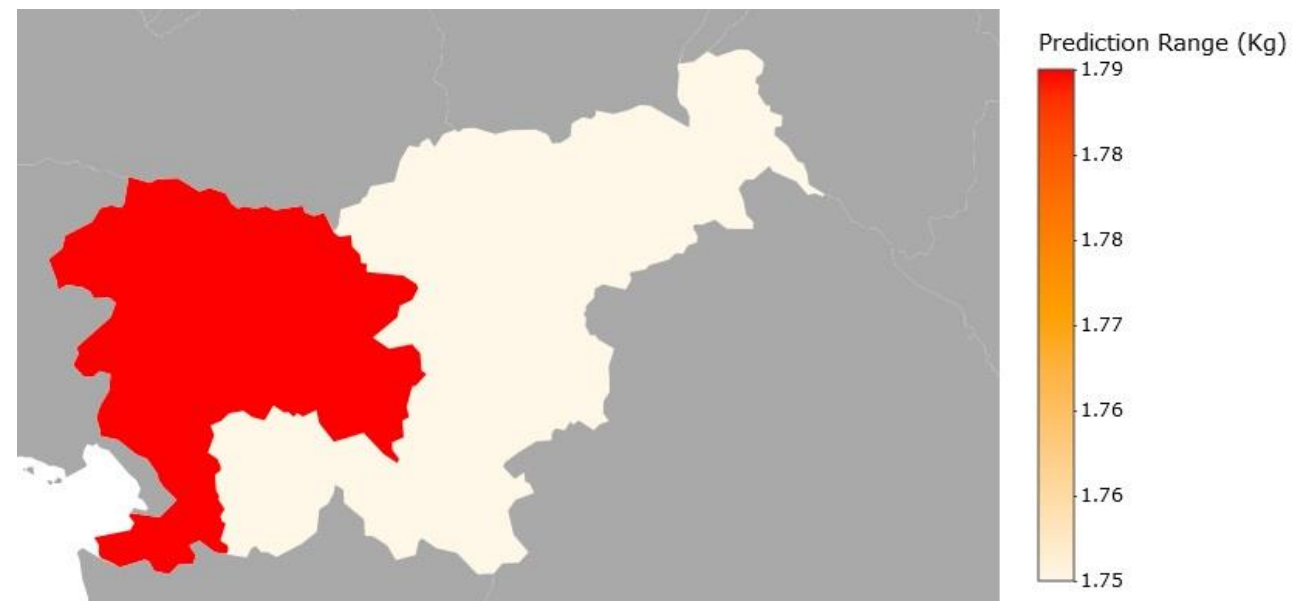

Table 26-2: Slovenia - FW estimation at regional level

\begin{tabular}{|c|c|c|c|c|c|c|}
\hline Region & $\begin{array}{l}\text { Household } \\
\text { FW }(\mathrm{kg} / \\
\text { year) }\end{array}$ & $\begin{array}{l}\text { Low } \\
95 \% \\
\text { (kg/ } \\
\text { year) }\end{array}$ & $\begin{array}{l}\text { Up } 95 \% \\
\text { (kg/year) }\end{array}$ & $\begin{array}{l}\text { Total FW } \\
\text { (tons/year) }\end{array}$ & $\begin{array}{l}\text { Low } \\
95 \% \\
\text { (tons/ } \\
\text { year) }\end{array}$ & $\begin{array}{l}\text { Up } 95 \% \\
\text { (tons/ } \\
\text { year) }\end{array}$ \\
\hline $\begin{array}{l}\text { Zahodna } \\
\text { Slovenija }\end{array}$ & 98.80 & 57.03 & 112.32 & 41,111 & 23,729 & 46,736 \\
\hline $\begin{array}{l}\text { Vzhodna } \\
\text { Slovenija }\end{array}$ & 96.72 & 55.64 & 110.24 & 44,975 & 25,873 & 51,262 \\
\hline Slovenia & 97.76 & 56.33 & 111.28 & 86,136 & 49,635 & 98,049 \\
\hline
\end{tabular}

Note: differences among the national values estimation and the sum of single regional values are due to computational approximations.

Source: REFRESH Road Map

The predicted food waste for Slovenia considering the actual regional values for GDP per capita and higher education level amounts to $\mathbf{9 7 . 7 6} \mathrm{kg}$ per household and an overall total of almost 86,136 tons per year.

At the regional level the lowest estimated values of food waste are registered in Vzhodna Slovenija. with an average household FW of $\mathbf{9 8 . 8 0} \mathbf{k g}$ per year while the highest are recorded in Zahodna Slovenija with a value of $\mathbf{9 8 . 8 0} \mathbf{k g}$ per year. 


\section{Slovakia}

Slovakia is divided in 4 regions (NUTS 2): Bratislavský kraj, Západné Slovensko, Stredné Slovensko, and Východné Slovensko.

According to 2017 Eurostat data, the population amounts to 5,434,343 The Gross Domestic Product (GDP) per capita on purchasing power parity is $\mathbf{2 2 , 4 0 0}$ euro, with consistent regional differences ranging from 17,900 euro per capita of Stredné Slovensko area to $\mathbf{5 2 , 8 0 0}$ euro per capita of the Bratislavský kraj region. There are $\mathbf{1 , 8 7 4 , 5 0 0}$ households, with an average size of $\mathbf{2 . 7}$ persons.

The average employment rate is $\mathbf{7 1 . 6 \%}$, while the level of tertiary education is $\mathbf{4 4 . 5 \%}$. Table 27-1 summarizes the baseline values based on Eurostat data.

Table 27-1: Slovakia - parameters for FW estimation at regional level

\begin{tabular}{lrrrrr} 
Region & $\begin{array}{l}\text { GDP } \\
\text { PPP } \\
\text { (EUR) }\end{array}$ & \multicolumn{1}{c}{$\begin{array}{l}\text { Tertiary } \\
\text { education level }\end{array}$} & $\begin{array}{l}\text { Median } \\
\text { age }\end{array}$ & Population & $\begin{array}{l}N^{\circ} \text { of } \\
\text { households }\end{array}$ \\
$\begin{array}{l}\text { Bratislavský } \\
\text { kraj }\end{array}$ & 52,800 & $43.8 \%$ & 40.1 & 641,892 & 258,800 \\
$\begin{array}{l}\text { Západné } \\
\text { Slovensko }\end{array}$ & 20,800 & $20.6 \%$ & 41.4 & $1,830,751$ & 645,800 \\
\hline $\begin{array}{l}\text { Stredné } \\
\text { Slovensko }\end{array}$ & 17,900 & $21.6 \%$ & 39.9 & $1,342,287$ & 468,800 \\
$\begin{array}{l}\text { Východné } \\
\text { Slovensko }\end{array}$ & 16,000 & $23.6 \%$ & 37.6 & $1,620,413$ & 501,100 \\
\hline Slovakia & 22,400 & $24.6 \%$ & 39.8 & $5,435,343$ & $1,874,500$
\end{tabular}

Source: author's elaboration on Eurostat data

Figure 21 and

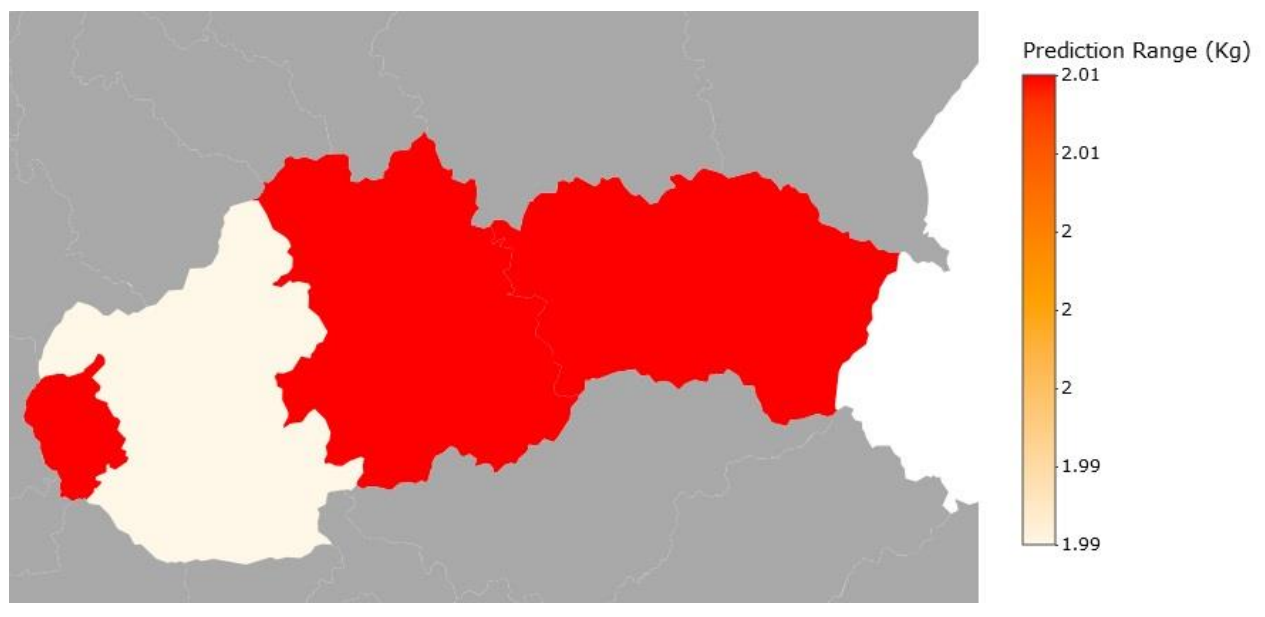

Table 27-2 summarize the food waste estimations for the country, both at the regional and national level, as developed by on basis of simulations run with the REFRESH Road Map (Stewart et al, 2019). 
Figure 21: estimated FW per household in Slovakia regions

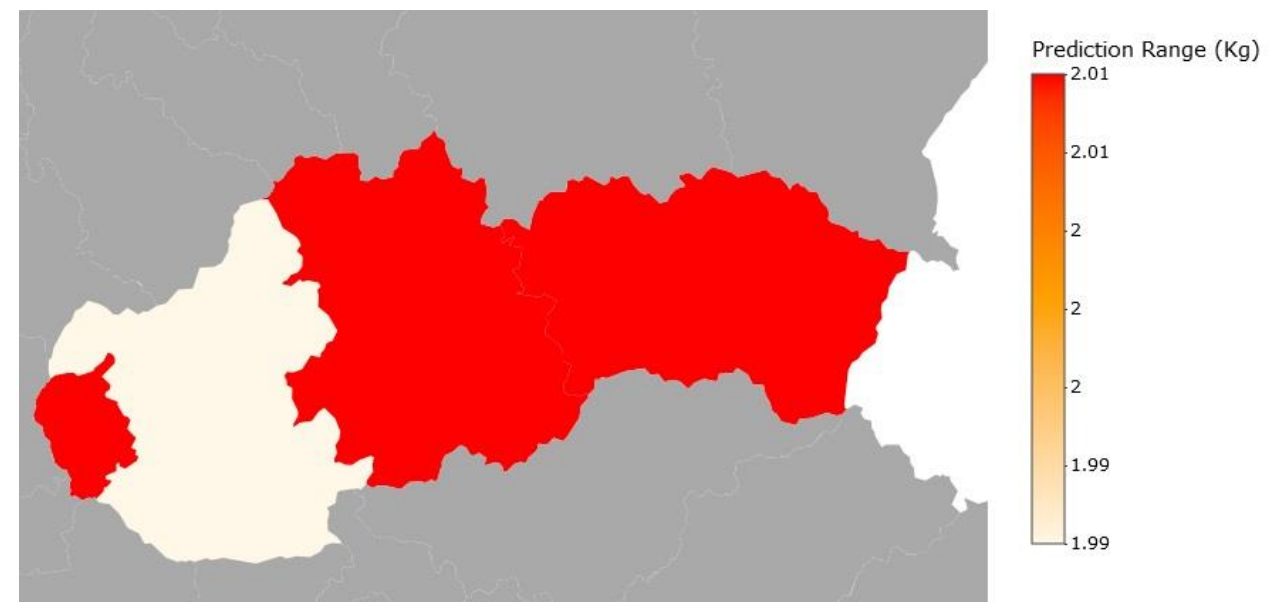

Table 27-2: Slovakia - FW estimation at regional level

\begin{tabular}{|c|c|c|c|c|c|c|}
\hline Region & $\begin{array}{l}\text { Household } \\
\text { FW (kg/ } \\
\text { year) }\end{array}$ & $\begin{array}{l}\text { Low } \\
95 \% \\
\text { (kg/ } \\
\text { year) }\end{array}$ & $\begin{array}{l}\text { Up } 95 \% \\
\text { (kg/year) }\end{array}$ & $\begin{array}{l}\text { Total FW } \\
\text { (tons/year) }\end{array}$ & $\begin{array}{l}\text { Low } \\
95 \% \\
\text { (tons/ } \\
\text { year) }\end{array}$ & $\begin{array}{l}\text { Up } 95 \% \\
\text { (tons/ } \\
\text { year) }\end{array}$ \\
\hline $\begin{array}{l}\text { Bratislavský } \\
\text { kraj }\end{array}$ & 129.48 & 77.48 & 143.00 & 33,509 & 20,052 & 37,008 \\
\hline $\begin{array}{l}\text { Východné } \\
\text { Slovensko }\end{array}$ & 129.48 & 77.31 & 143.00 & 64,882 & 38,738 & 71,657 \\
\hline $\begin{array}{l}\text { Stredné } \\
\text { Slovensko }\end{array}$ & 129.22 & 77.31 & 143.00 & 60,578 & 36,241 & 67,038 \\
\hline $\begin{array}{l}\text { Západné } \\
\text { Slovensko }\end{array}$ & 128.44 & 76.79 & 141.44 & 82,947 & 49,589 & 91,342 \\
\hline Slovenia & 128.96 & 77.31 & 142.74 & 241,736 & 144,911 & 267,566 \\
\hline
\end{tabular}

Note: differences among the national values estimation and the sum of single regional values are due to computational approximations.

Source: REFRESH Road Map

The predicted food waste for Slovakia considering the actual regional values for GDP per capita and higher education level amounts to $\mathbf{1 2 8 . 9 6} \mathrm{kg}$ per household and an overall total of almost 241,736 tons per year.

At the regional level, the lowest estimated values of food waste are registered in Západné Slovensko with an average household FW of $\mathbf{1 2 8 . 4 4} \mathrm{kg}$ per year while the highest are recorded in Bratislavský kraj with a value of $\mathbf{1 2 9 . 4 8} \mathrm{kg}$ per year. 


\section{Spain}

Spain is divided in 19 regions (NUTS 2): Galicia, Principality of Asturias, Cantabria, Basque Community, Navarre, La Rioja, Aragon, Madrid Community, Castile-Leon, Castile-La Mancha, Extremadura, Catalonia, Valencian Community, Balearic Islands, Andalusia, Region of Murcia, Ceuta, Melilla, and Canary Islands.

According to 2017 Eurostat data, the population amounts to 46,528,024 The Gross Domestic Product (GDP) per capita on purchasing power parity is $\mathbf{2 7 . 1 0 0}$ euro, with some regional differences ranging from 19,000 euro per capita of Extremadura area to $\mathbf{3 6 , 6 0 0}$ euro per capita of the Madrid region.

There are 18,512,500 households, with an average size of $\mathbf{2 . 5}$ persons.

The average employment rate is $\mathbf{5 3 . 5 \%}$, while the level of tertiary education is $\mathbf{3 1 . 7 \%}$. Table 28-1 summarizes the baseline values based on Eurostat data.

Table 28-1: Spain - parameters for FW estimation at regional level

\begin{tabular}{|c|c|c|c|c|c|}
\hline Region & $\begin{array}{l}\text { GDP PPP } \\
\text { (EUR) }\end{array}$ & $\begin{array}{l}\text { Tertiary } \\
\text { education } \\
\text { level }\end{array}$ & $\begin{array}{l}\text { Median } \\
\text { age }\end{array}$ & Population & $\begin{array}{l}N^{\circ} \text { of } \\
\text { households }\end{array}$ \\
\hline Galicia & 27,100 & $36.9 \%$ & 47.1 & $2,710,216$ & $1,089,700$ \\
\hline $\begin{array}{l}\text { Principality of } \\
\text { Asturias }\end{array}$ & 24,200 & $43.1 \%$ & 48.8 & $1,034,302$ & 456,100 \\
\hline Cantabria & 24,000 & $40.6 \%$ & 45.6 & 581,490 & 240,500 \\
\hline $\begin{array}{l}\text { Basque } \\
\text { Community }\end{array}$ & 24,500 & $49.6 \%$ & 46.0 & $2,167,323$ & 902,100 \\
\hline Navarre & 35,600 & $45.4 \%$ & 43.4 & 640,353 & 256,500 \\
\hline La Rioja & 33,400 & $38.7 \%$ & 44.4 & 312,624 & 129,900 \\
\hline Aragon & 28,300 & $38.4 \%$ & 44.8 & $1,316,072$ & 537,500 \\
\hline $\begin{array}{l}\text { Madrid } \\
\text { Community }\end{array}$ & 29,900 & $47.2 \%$ & 42.2 & $6,476,838$ & $2,587,700$ \\
\hline Castile-Leon & 36,600 & $36.2 \%$ & 47.9 & $2,435,951$ & $1,025,000$ \\
\hline $\begin{array}{l}\text { Castile-La } \\
\text { Mancha }\end{array}$ & 25,300 & $28.4 \%$ & 42.5 & $2,040,977$ & 784,700 \\
\hline Extremadura & $21, .400$ & $26.5 \%$ & 44.2 & $1,077,525$ & 430,500 \\
\hline Catalonia & 19,000 & $40.8 \%$ & 42.8 & $7,441,284$ & $2,993,300$ \\
\hline $\begin{array}{l}\text { Valencian } \\
\text { Community }\end{array}$ & 32,500 & $35.7 \%$ & 43.3 & $4,935,182$ & $1,998,000$ \\
\hline Balearic Islands & 23,800 & $29.7 \%$ & 41.1 & $1,150,962$ & 448,100 \\
\hline
\end{tabular}




\begin{tabular}{lllrrr|} 
Andalusia & 28,400 & $30.3 \%$ & 41.5 & $8,408,976$ & $3,209,100$ \\
\hline $\begin{array}{l}\text { Region of } \\
\text { Murcia }\end{array}$ & 20,100 & $31.2 \%$ & 40.3 & $1,472,991$ & 539,400 \\
\hline Ceuta & 22,300 & $26.5 \%$ & 36.6 & 85,034 & 28,300 \\
\hline Melilla & 21,100 & $29.9 \%$ & 33.9 & 84,946 & 25,100 \\
\hline Canary Islands & 19,500 & $30.5 \%$ & 42.3 & $2,154,978$ & 831,000 \\
\hline Spain & 19,800 & $37.3 \%$ & 43.2 & $46,528,024$ & $18,512,500$ \\
\hline
\end{tabular}

Source: author's elaboration on Eurostat data

Figure 22 and

Table 28-2 summarize the food waste estimations for the country, both at the regional and national level, as developed by on basis of simulations run with the REFRESH Road Map (Stewart et al, 2019). 
Figure 22: estimated FW per household in Spanish regions

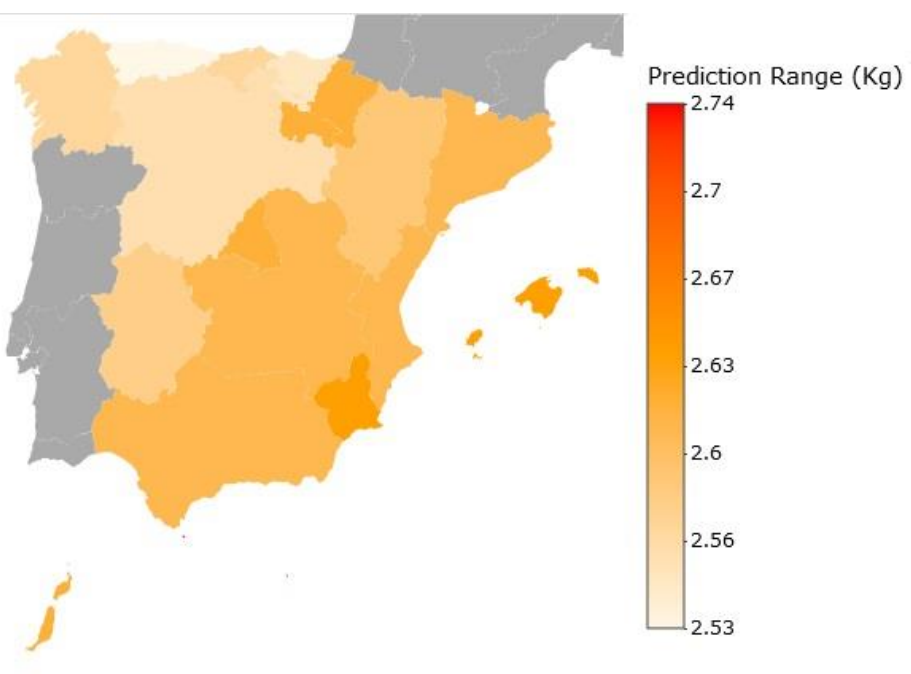

Table 28-2: Spain - FW estimation at regional level

\begin{tabular}{|c|c|c|c|c|c|c|}
\hline Region & $\begin{array}{l}\text { Household } \\
\text { FW ( } \mathrm{kg} / \\
\text { year) }\end{array}$ & $\begin{array}{l}\text { Low } \\
95 \% \\
\text { (kg/ } \\
\text { year) }\end{array}$ & $\begin{array}{l}\text { Up } 95 \% \\
\text { (kg/year) }\end{array}$ & $\begin{array}{l}\text { Total FW } \\
\text { (tons/year) }\end{array}$ & $\begin{array}{l}\text { Low 95\% } \\
\text { (tons/ } \\
\text { year) }\end{array}$ & $\begin{array}{l}\text { Up 95\% } \\
\text { (tons/ } \\
\text { year) }\end{array}$ \\
\hline Melilla & 142.48 & 85.97 & 162.24 & 3,576 & 2,158 & 4,072 \\
\hline Ceuta & 133.90 & 80.08 & 147.94 & 3,789 & 2,266 & 4,187 \\
\hline Navarre & 128.70 & 76.96 & 142.22 & 33,012 & 19,740 & 36,479 \\
\hline $\begin{array}{l}\text { Balearic } \\
\text { Islands }\end{array}$ & 128.70 & 76.79 & 142.48 & 57,670 & 34,408 & 63,845 \\
\hline Murcia & 128.96 & 76.96 & 142.74 & 69,561 & 41,512 & 76,994 \\
\hline La Rioja & 128.44 & 76.79 & 142.48 & 16,684 & 9,975 & 18,508 \\
\hline Madrid & 128.44 & 76.79 & 141.96 & 332,364 & 198,701 & 367,350 \\
\hline Catalonia & 127.14 & 75.75 & 140.66 & 380,568 & 226,732 & 421,038 \\
\hline $\begin{array}{l}\text { Valencian } \\
\text { Community }\end{array}$ & 127.92 & 76.27 & 141.44 & 255,584 & 152,381 & 282,597 \\
\hline Andalusia & 127.92 & 76.27 & 141.44 & 410,508 & 244,747 & 453,895 \\
\hline $\begin{array}{l}\text { Canary } \\
\text { Islands }\end{array}$ & 127.92 & 76.61 & 141.7 & 106,302 & 63,666 & 117,753 \\
\hline $\begin{array}{l}\text { Castile-La } \\
\text { Mancha }\end{array}$ & 127.40 & 76.27 & 140.92 & 99,971 & 59,846 & 110,580 \\
\hline
\end{tabular}




\begin{tabular}{|lrrr|rrr|}
\hline Aragon & 126.88 & 75.57 & 140.4 & 68,198 & 40,621 & 75,465 \\
\hline Cantabria & 126.10 & 75.23 & 139.88 & 30,327 & 18,092 & 33,641 \\
\hline Galicia & 125.84 & 74.88 & 139.36 & 137,128 & 81,597 & 151,861 \\
\hline Extremadura & 125.58 & 74.88 & 139.1 & 54,062 & 32,236 & 59,883 \\
\hline $\begin{array}{l}\text { Basque } \\
\text { Community }\end{array}$ & 125.32 & 74.88 & 139.1 & 113,051 & 67,549 & 125,482 \\
\hline Castile-Leon & 124.54 & 74.19 & 138.06 & 127,654 & 76,041 & 141,512 \\
\hline Asturias & 124.02 & 74.01 & 137.54 & 56,566 & 33,757 & 62,732 \\
\hline Spain & 127.92 & 76.27 & 141.44 & $2,368,119$ & $1,411,887$ & $2,618,408$ \\
\hline
\end{tabular}

Note: differences among the national values estimation and the sum of single regional values are due to computational approximations.

Source: REFRESH Road Map

The predicted food waste for Spain, considering the actual regional values for GDP per capita and higher education level amounts to $\mathbf{1 2 7 . 9 2} \mathrm{kg}$ per household and an overall total of almost $\mathbf{2 , 3 6 8 , 1 1 9}$ tons per year.

At the regional level the lowest estimated values of food waste are registered in Principality of Asturias, with an average household FW of $\mathbf{1 2 4 . 0 2} \mathrm{kg}$ per year, while the highest are recorded in Melilla, with a value of $\mathbf{1 4 2 . 4 8} \mathrm{kg}$ per year. 


\section{Sweden}

Sweden territory is divided in 8 regions (NUTS 2): Stockholm, Östra Mellansverige, Småland med öarna, Sydsverige, Västsverige, Norra Mellansverige, Mellersta Norrland, and Övre Norrland.

According to 2017 Eurostat data, the population amounts to 9,995,153 The Gross Domestic Product (GDP) per capita on purchasing power parity is $\mathbf{3 5 , 6 0 0}$ euro, with some regional differences ranging from $\mathbf{2 8 , 6 0 0}$ euro per capita of Norra Mellansverige area to $\mathbf{4 8 , 8 0 0}$ euro per capita of the Stockholm region.

There are $\mathbf{4 , 8 6 2 , 7 0 0}$ households, with an average size of $\mathbf{1 . 8}$ persons.

The average employment rate is $\mathbf{7 6 . 9 \%}$, while the level of tertiary education is 43.3\%. Table 29-1 summarizes the baseline values based on Eurostat data.

Table 29-1: Sweden - parameters for FW estimation at regional level

\begin{tabular}{|c|c|c|c|c|c|}
\hline Region & $\begin{array}{l}\text { GDP } \\
\text { PPP } \\
\text { (EUR) }\end{array}$ & $\begin{array}{l}\text { Tertiary } \\
\text { education } \\
\text { level }\end{array}$ & $\begin{array}{l}\text { Median } \\
\text { age }\end{array}$ & Population & $\begin{array}{l}N^{\circ} \text { of } \\
\text { households }\end{array}$ \\
\hline Stockholm & 48,800 & $52.0 \%$ & 38.1 & $2,269,060$ & $1,130,400$ \\
\hline $\begin{array}{l}\text { Östra } \\
\text { Mellansverige }\end{array}$ & 30,800 & $40.2 \%$ & 41.1 & $1,664,145$ & 809,200 \\
\hline $\begin{array}{l}\text { Småland med } \\
\text { öarna }\end{array}$ & 30,700 & $36.2 \%$ & 42.7 & 847,667 & 395,600 \\
\hline Sydsverige & 30,700 & $45.4 \%$ & 40.6 & $1,483,018$ & 703,700 \\
\hline Västsverige & 35,100 & $42.3 \%$ & 40.7 & $1,992,116$ & 956,200 \\
\hline $\begin{array}{l}\text { Norra } \\
\text { Mellansverige }\end{array}$ & 28,600 & $34.0 \%$ & 44.5 & 848,451 & 420,200 \\
\hline $\begin{array}{l}\text { Mellersta } \\
\text { Norrland }\end{array}$ & 30,000 & $36.5 \%$ & 44.4 & 374,245 & 185,600 \\
\hline Övre Norrland & 32,800 & $39.9 \%$ & 42.8 & 516,451 & 261,800 \\
\hline Sweden & 35,600 & $43.3 \%$ & 40.8 & $9,995,153$ & $4,862,700$ \\
\hline
\end{tabular}

Source: author's elaboration on Eurostat data 


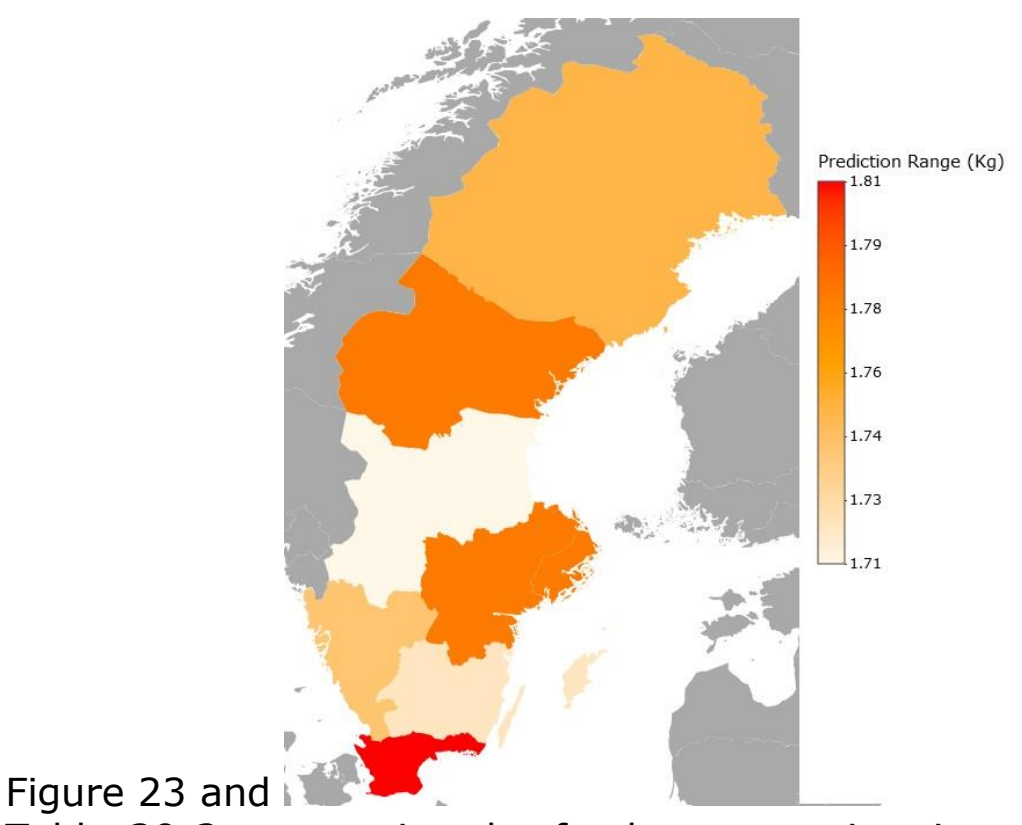

Table 29-2 summarize the food waste estimations for the country, both at the regional and national level, as developed by on basis of simulations run with the REFRESH Road Map (Stewart et al, 2019). 
Figure 23: estimated FW per household in Swedish regions

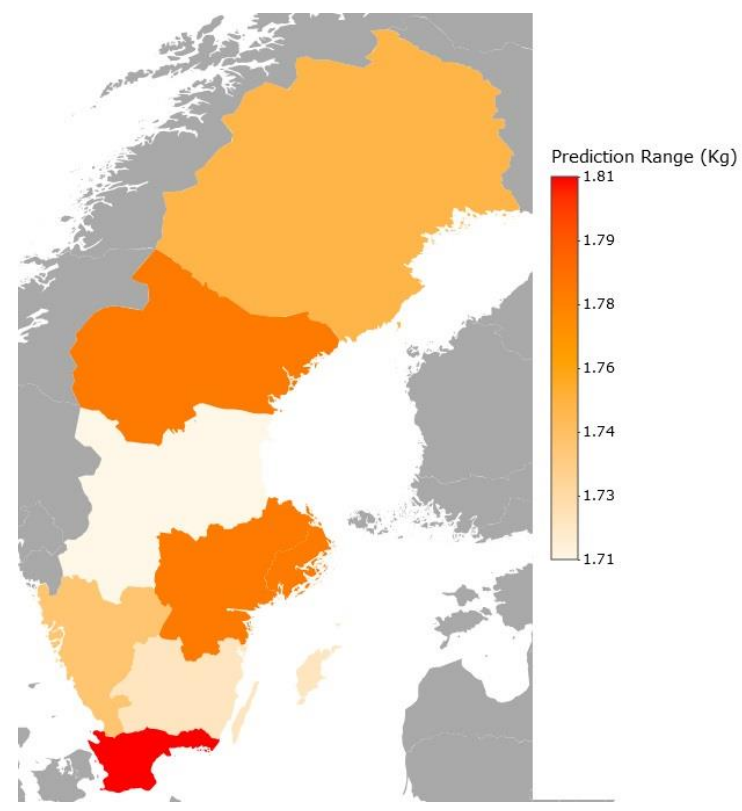

Table 29-2: Sweden - FW estimation at regional level

\begin{tabular}{|c|c|c|c|c|c|c|}
\hline Region & $\begin{array}{l}\text { Household } \\
\text { FW }(\mathrm{kg} / \\
\text { year) }\end{array}$ & $\begin{array}{l}\text { Low } \\
95 \% \\
\text { (kg/ } \\
\text { year) }\end{array}$ & $\begin{array}{l}\text { Up } 95 \% \\
\text { (kg/year) }\end{array}$ & $\begin{array}{l}\text { Total FW } \\
\text { (tons/year) }\end{array}$ & $\begin{array}{l}\text { Low } \\
95 \% \\
\text { (tons/ } \\
\text { year) }\end{array}$ & $\begin{array}{l}\text { Up 95\% } \\
\text { (tons/ } \\
\text { year) }\end{array}$ \\
\hline Sydsverige & 100.62 & 58.24 & 114.14 & 70,806 & 40,983 & 80,320 \\
\hline Stockholm & 98.80 & 56.85 & 112.84 & 111,684 & 64,267 & 127,554 \\
\hline $\begin{array}{l}\text { Östra } \\
\text { Mellansverige }\end{array}$ & 98.28 & 56.85 & 111.8 & 79,528 & 46,006 & 90,469 \\
\hline $\begin{array}{l}\text { Mellersta } \\
\text { Norrland }\end{array}$ & 98.28 & 56.68 & 111.8 & 18,241 & 10,520 & 20,750 \\
\hline Västsverige & 96.72 & 55.47 & 110.24 & 92,484 & 53,037 & 105,411 \\
\hline $\begin{array}{l}\text { Övre } \\
\text { Norrland }\end{array}$ & 96.72 & 55.81 & 110.5 & 25,321 & 14,612 & 28,929 \\
\hline $\begin{array}{l}\text { Småland med } \\
\text { öarna }\end{array}$ & 95.68 & 54.77 & 109.2 & 37,851 & 21,668 & 43,200 \\
\hline $\begin{array}{l}\text { Norra } \\
\text { Mellansverige }\end{array}$ & 94.64 & 54.25 & 108.16 & 39,768 & 22,797 & 45,449 \\
\hline Sweden & 97.50 & 56.16 & 111.28 & 474,113 & 273,089 & 541,121 \\
\hline
\end{tabular}

Note: differences among the national values estimation and the sum of single regional values are due to computational approximations.

Source: REFRESH Road Map 
The predicted food waste for Sweden, considering the actual regional values for GDP per capita and higher education level amounts to $\mathbf{9 7 . 5 0} \mathbf{k g}$ per household and an overall total of almost $\mathbf{4 7 4 , 1 1 3}$ tons per year,

At the regional level, the lowest estimated values of food waste are registered in Norra Mellansverige, with an average household FW of $96.94 \mathrm{~kg}$ per year, while the highest are recorded in Sydsverige, with a value of $\mathbf{1 0 0 . 6 2} \mathbf{k g}$ per year. 


\section{United Kingdom}

United Kingdom is divided in 41 regions (NUTS 2): Tees Valley and Durham, Northumberland and Tyne and Wear, Cumbria, Greater Manchester, Lancashire, Cheshire, Merseyside, East Yorkshire and Northern Lincolnshire, North Yorkshire, South Yorkshire, West Yorkshire, Derbyshire and Nottinghamshire, Leicestershire, Rutland and Northamptonshire, Lincolnshire, Herefordshire, Worcestershire and Warwickshire, Shropshire and Staffordshire, West Midlands, East Anglia, Bedfordshire and Hertfordshire, Essex, Inner London - West, Inner London - East, Outer London - East and North East, Outer London - South, Outer London - West and North West, Berkshire, Buckinghamshire and Oxfordshire, Surrey, East and West Sussex, Hampshire and Isle of Wight, Kent, Gloucestershire, Wiltshire and Bristol/Bath Area, Dorset and Somerset, Cornwall and Isles of Scilly, Devon, West Wales and The Valleys, East Wales, North Eastern Scotland, Highlands and Islands, Eastern Scotland, West Central Scotland, Southern Scotland, and Northern Ireland. According to 2017 Eurostat data, the population amounts to $65,844,122$ The Gross Domestic Product (GDP) per capita on purchasing power parity is $\mathbf{3 1 , 1 0 0}$ euro, with consistent regional differences ranging from 19,000 euro per capita of Southern Scotland area to the 49,600 euro per capita of the Inner London - East region, and with the relevant exception of the Inner London - West region, with a GDP of $\mathbf{1 8 4 , 6 0 0}$ euro per capita

There are $\mathbf{2 8 , 8 3 0 , 1 0 0}$ households, with an average size of $\mathbf{2 . 3}$ persons, and the number of households is, according to Eurostat data.

The average employment rate is $\mathbf{7 4 . 1 \%}$, while the level of tertiary education is 43.2\%. Table 30-1 summarizes the baseline values based on Eurostat data.

Table 30-1: United Kingdom - parameters for FW estimation at regional level

\begin{tabular}{|c|c|c|c|c|c|}
\hline Region & $\begin{array}{l}\text { GDP } \\
\text { PPP } \\
\text { (EUR) }\end{array}$ & $\begin{array}{l}\text { Tertiary } \\
\text { education } \\
\text { level }\end{array}$ & $\begin{array}{l}\text { Median } \\
\text { age }\end{array}$ & Population & $\begin{array}{l}N^{\circ} \text { of } \\
\text { households }\end{array}$ \\
\hline $\begin{array}{l}\text { Tees Valley and } \\
\text { Durham }\end{array}$ & 20,600 & $32.2 \%$ & 42.1 & $1,194,437$ & 544,600 \\
\hline $\begin{array}{l}\text { Northumberland } \\
\text { and Tyne and } \\
\text { Wear }\end{array}$ & 24,500 & $34.7 \%$ & 41.7 & $1,446,249$ & 632,700 \\
\hline Cumbria & 26,200 & $35.1 \%$ & 47.1 & 498,641 & 243,500 \\
\hline $\begin{array}{l}\text { Greater } \\
\text { Manchester }\end{array}$ & 26,800 & $38.8 \%$ & 37.1 & $2,789,735$ & $1,198,000$ \\
\hline Lancashire & 24,800 & $37.8 \%$ & 42.0 & $1,487,102$ & 633,800 \\
\hline Cheshire & 37,700 & $46.6 \%$ & 44.3 & 924,261 & 403,400 \\
\hline Merseyside & 23,400 & $36.6 \%$ & 40.5 & $1,541,473$ & 696,200 \\
\hline
\end{tabular}




\begin{tabular}{|c|c|c|c|c|c|}
\hline $\begin{array}{l}\text { East Yorkshire } \\
\text { and Northern } \\
\text { Lincolnshire }\end{array}$ & 22,600 & $31.5 \%$ & 43.2 & 929,189 & 422,000 \\
\hline North Yorkshire & 26,400 & $47.7 \%$ & 45.2 & 818,141 & 363,000 \\
\hline South Yorkshire & 21,100 & $39.4 \%$ & 39.1 & $1,389,426$ & 609,100 \\
\hline West Yorkshire & 26,000 & $37.3 \%$ & 37.7 & $2,301,000$ & 987,000 \\
\hline $\begin{array}{l}\text { Derbyshire and } \\
\text { Nottinghamshire }\end{array}$ & 24,000 & $37.2 \%$ & 41.3 & $2,187,643$ & 953,500 \\
\hline $\begin{array}{l}\text { Leicestershire, } \\
\text { Rutland and } \\
\text { Northamptonshire }\end{array}$ & 27,300 & $38.8 \%$ & 39.8 & $1,812,852$ & 739,800 \\
\hline Lincolnshire & 20,400 & $35.9 \%$ & 45.4 & 747,996 & 329,500 \\
\hline $\begin{array}{l}\text { Herefordshire, } \\
\text { Worcestershire } \\
\text { and Warwickshire }\end{array}$ & 28,700 & $42.8 \%$ & 44.4 & $1,338,055$ & 580,800 \\
\hline $\begin{array}{l}\text { Shropshire and } \\
\text { Staffordshire }\end{array}$ & 22,500 & $36.9 \%$ & 43.4 & $1,613,788$ & 687,100 \\
\hline West Midlands & 26,000 & $32.6 \%$ & 35.6 & $2,883,905$ & $1,129,800$ \\
\hline East Anglia & 27,500 & $38.0 \%$ & 43.1 & $2,493,326$ & $1,108,800$ \\
\hline $\begin{array}{l}\text { Bedfordshire and } \\
\text { Hertfordshire }\end{array}$ & 32,000 & $46.4 \%$ & 39.2 & $1,841,673$ & 770,900 \\
\hline Essex & 24,600 & $33.5 \%$ & 42.0 & $1,813,609$ & 767,900 \\
\hline $\begin{array}{l}\text { Inner London - } \\
\text { West }\end{array}$ & 184,600 & $71.5 \%$ & 34.9 & $1,163,136$ & 573,600 \\
\hline $\begin{array}{l}\text { Inner London - } \\
\text { East }\end{array}$ & 49,600 & $62.6 \%$ & 32.6 & $2,367,065$ & $1,150,400$ \\
\hline $\begin{array}{l}\text { Outer London - } \\
\text { East and North } \\
\text { East }\end{array}$ & 21,300 & $46.3 \%$ & 35.5 & $1,899,556$ & 772,800 \\
\hline $\begin{array}{l}\text { Outer London - } \\
\text { South }\end{array}$ & 26,400 & $52.7 \%$ & 37.9 & $1,295,666$ & 576,700 \\
\hline $\begin{array}{l}\text { Outer London - } \\
\text { West and North } \\
\text { West }\end{array}$ & 37,900 & $55.9 \%$ & 36.4 & $2,071,842$ & 851,000 \\
\hline
\end{tabular}




\begin{tabular}{|c|c|c|c|c|c|}
\hline $\begin{array}{l}\text { Berkshire, } \\
\text { Buckinghamshire } \\
\text { and Oxfordshire }\end{array}$ & 42,700 & $53.0 \%$ & 39.3 & $2,385,514$ & 978,400 \\
\hline $\begin{array}{l}\text { Surrey, East and } \\
\text { West Sussex }\end{array}$ & 32,100 & $50.4 \%$ & 43.0 & $2,871,387$ & $1,259,900$ \\
\hline $\begin{array}{l}\text { Hampshire and } \\
\text { Isle of Wight }\end{array}$ & 30,600 & $42.9 \%$ & 41.8 & $1,973,952$ & 866,900 \\
\hline Kent & 25,500 & $37.7 \%$ & 41.4 & $1,824,794$ & 786,500 \\
\hline $\begin{array}{l}\text { Gloucestershire, } \\
\text { Wiltshire and } \\
\text { Bristol/Bath Area }\end{array}$ & 31,200 & $45.7 \%$ & 40.7 & $2,474,784$ & $1,107,900$ \\
\hline $\begin{array}{l}\text { Dorset and } \\
\text { Somerset }\end{array}$ & 24,000 & $39.4 \%$ & 46.2 & $1,322,286$ & 590,800 \\
\hline $\begin{array}{l}\text { Cornwall and } \\
\text { Isles of Scilly }\end{array}$ & 19,900 & $41.2 \%$ & 46.8 & 560,526 & 257,800 \\
\hline Devon & 22,800 & $43.1 \%$ & 45.4 & $1,180,517$ & 546,900 \\
\hline $\begin{array}{l}\text { West Wales and } \\
\text { The Valleys }\end{array}$ & 19,400 & $37.0 \%$ & 43.5 & $1,960,764$ & 864,400 \\
\hline East Wales & 27,700 & $43.2 \%$ & 40.5 & $1,158,491$ & 529,800 \\
\hline $\begin{array}{l}\text { North Eastern } \\
\text { Scotland }\end{array}$ & 42,800 & $46.7 \%$ & 40.0 & 491,323 & 226,600 \\
\hline $\begin{array}{l}\text { Highlands and } \\
\text { Islands }\end{array}$ & 27,500 & $44.6 \%$ & 46.4 & 469,420 & 227,100 \\
\hline Eastern Scotland & 31,900 & $52.3 \%$ & 41.0 & $1,976,392$ & 908,300 \\
\hline $\begin{array}{l}\text { West Central } \\
\text { Scotland }\end{array}$ & 26,700 & $44.4 \%$ & 39.8 & $1,531,216$ & 717,000 \\
\hline $\begin{array}{l}\text { Southern } \\
\text { Scotland }\end{array}$ & 19,000 & $43.8 \%$ & 45.9 & 946,372 & 435,900 \\
\hline Northern Ireland & 23,900 & $37.2 \%$ & 38.4 & $1,866,638$ & 800,000 \\
\hline United Kingdom & 31,100 & $43.2 \%$ & 40.0 & $65,844,142$ & $28,830,100$ \\
\hline
\end{tabular}

Source: author's elaboration on Eurostat data 


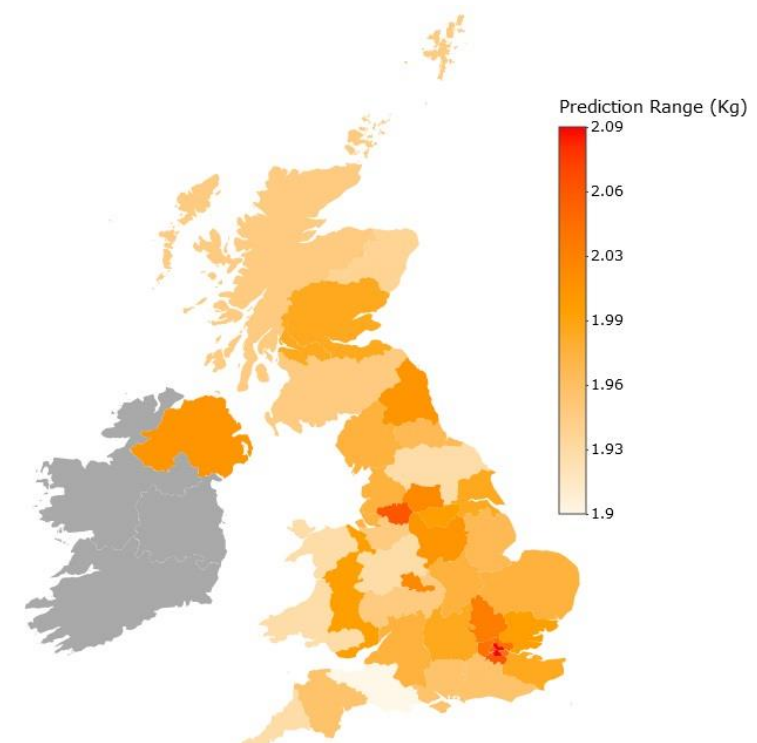

Figure 24 and

Table 30-2 summarize the food waste estimations for the country, both at the regional and national level, as developed by on basis of simulations run with the REFRESH Road Map (Stewart et al, 2019).

Figure 24: estimated FW per household in English regions

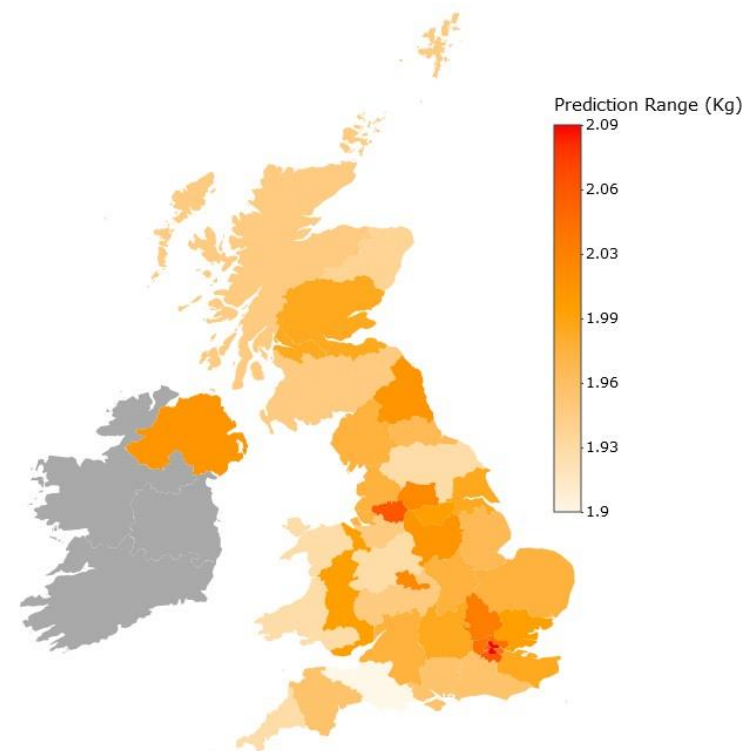

Table 30-2: United Kingdom - FW estimation at regional level

\begin{tabular}{|c|c|c|c|c|c|c|}
\hline Region & $\begin{array}{l}\text { Household FW } \\
\text { (kg/ year) }\end{array}$ & $\begin{array}{l}\text { Low } \\
95 \% \\
\text { (kg/ } \\
\text { year) }\end{array}$ & $\begin{array}{l}\text { Up } 95 \% \\
\text { (kg/year) }\end{array}$ & $\begin{array}{l}\text { Total FW } \\
\text { (tons/year) }\end{array}$ & $\begin{array}{l}\text { Low 95\% } \\
\text { (tons/ } \\
\text { year) }\end{array}$ & $\begin{array}{l}\text { Up } 95 \% \\
\text { (tons/ } \\
\text { year) }\end{array}$ \\
\hline
\end{tabular}




\begin{tabular}{|c|c|c|c|c|c|c|}
\hline $\begin{array}{l}\text { Inner London - } \\
\text { East }\end{array}$ & 103.48 & 59.97 & 117.00 & 119,043 & $68,, 993$ & $134,, 597$ \\
\hline $\begin{array}{l}\text { Outer London - } \\
\text { South }\end{array}$ & 101.92 & 59.11 & 115.70 & 58,777 & $34,, 087$ & $66,, 724$ \\
\hline $\begin{array}{l}\text { Greater } \\
\text { Manchester }\end{array}$ & 101.40 & 58.59 & 114.92 & 121,477 & 70,187 & $137,, 674$ \\
\hline $\begin{array}{l}\text { Outer London - } \\
\text { East and North } \\
\text { East }\end{array}$ & 100.88 & 58.07 & 114.40 & 77,960 & $44,, 874$ & 88,408 \\
\hline $\begin{array}{l}\text { Outer London - } \\
\text { West and North } \\
\text { West }\end{array}$ & 100.88 & 58.07 & 114.40 & 85,849 & 49,415 & 97,354 \\
\hline $\begin{array}{l}\text { Bedfordshire and } \\
\text { Hertfordshire }\end{array}$ & 99.84 & 57.55 & 113.36 & $76,, 967$ & $44,, 363$ & $87,, 389$ \\
\hline West Yorkshire & 99.32 & 57.20 & 112.84 & $98,, 029$ & 56,456 & 111,373 \\
\hline West Midlands & 99.06 & 57.20 & 112.58 & $111,, 918$ & $64,, 625$ & 127,193 \\
\hline $\begin{array}{l}\text { Derbyshire and } \\
\text { Nottinghamshire }\end{array}$ & 98.80 & 56.85 & 112.32 & 94,206 & $54,, 210$ & 107,097 \\
\hline $\begin{array}{l}\text { Inner London - } \\
\text { West }\end{array}$ & 98.80 & 57.03 & 112.58 & $56,, 672$ & 32,710 & $64,, 576$ \\
\hline Northern Ireland & 98.80 & 56.68 & 112.84 & $79,, 040$ & 45,344 & 90,272 \\
\hline $\begin{array}{l}\text { Northumberland } \\
\text { and Tyne and } \\
\text { Wear }\end{array}$ & 98.28 & 56.51 & 111.80 & 62,182 & 35,752 & 70,736 \\
\hline South Yorkshire & 98.28 & 56.51 & 112.06 & 59,862 & 34,418 & 68,256 \\
\hline Essex & 98.28 & 56.51 & 111.54 & 75,469 & 43,391 & 85,652 \\
\hline East Wales & 98.28 & 56.85 & 112.06 & 52,069 & 30,121 & 59,369 \\
\hline Eastern Scotland & 98.28 & 56.68 & 111.54 & 89,268 & 51,482 & 101,312 \\
\hline $\begin{array}{l}\text { West Central } \\
\text { Scotland }\end{array}$ & 98.02 & 56.51 & 111.80 & 70,280 & 40,515 & 80,161 \\
\hline $\begin{array}{l}\text { Berkshire, } \\
\text { Buckinghamshire } \\
\text { and Oxfordshire }\end{array}$ & 97.76 & 56.33 & 111.80 & 95,648 & 55,117 & 109,385 \\
\hline $\begin{array}{l}\text { East Yorkshire } \\
\text { and Northern } \\
\text { Lincolnshire }\end{array}$ & 97.24 & 55.81 & 110.76 & 41,035 & 23,553 & 46,741 \\
\hline
\end{tabular}




\begin{tabular}{|c|c|c|c|c|c|c|}
\hline $\begin{array}{l}\text { Leicestershire, } \\
\text { Rutland and } \\
\text { Northamptonshire }\end{array}$ & 97.24 & 55.99 & 110.76 & 71,938 & 41,419 & 81,940 \\
\hline Kent & 97.24 & 56.16 & 110.76 & 76,479 & 44,170 & 87,113 \\
\hline $\begin{array}{l}\text { Gloucestershire, } \\
\text { Wiltshire and } \\
\text { Bristol/Bath Area }\end{array}$ & 97.24 & 56.16 & 110.76 & 107,732 & 62,220 & 122,711 \\
\hline Lancashire & 96.98 & 55.81 & 110.76 & 61,466 & 35,374 & 70,200 \\
\hline Cumbria & 96.72 & 55.64 & 110.76 & 23,551 & 13,548 & 26,970 \\
\hline Merseyside & 96.72 & 55.81 & 110.76 & 67,336 & 38,857 & 77,111 \\
\hline Lincolnshire & 96.72 & 55.81 & 110.24 & 31,869 & 18,390 & 36,324 \\
\hline East Anglia & 96.72 & 55.81 & 110.24 & 107,243 & 61,886 & 122,234 \\
\hline $\begin{array}{l}\text { Tees Valley and } \\
\text { Durham }\end{array}$ & 96.46 & 55.47 & 109.98 & 52,532 & 30,207 & 59,895 \\
\hline $\begin{array}{l}\text { Surrey, East and } \\
\text { West Sussex }\end{array}$ & 96.20 & 55.47 & 109.72 & 121,202 & 69,882 & 138,236 \\
\hline $\begin{array}{l}\text { Hampshire and } \\
\text { Isle of Wight }\end{array}$ & 96.20 & 55.47 & 109.72 & 83,396 & 48,084 & 95,116 \\
\hline Devon & 96.20 & 55.29 & 109.72 & 52,612 & 30,240 & 60,006 \\
\hline $\begin{array}{l}\text { Southern } \\
\text { Scotland }\end{array}$ & 96.20 & 55.12 & 109.98 & 41,934 & 24,027 & 47,940 \\
\hline $\begin{array}{l}\text { Highlands and } \\
\text { Islands }\end{array}$ & 95.94 & 55.12 & 109.46 & 21,788 & 12,518 & 24,858 \\
\hline Cheshire & 95.68 & 54.77 & 109.72 & 38,597 & 22,096 & 44,261 \\
\hline $\begin{array}{l}\text { Herefordshire, } \\
\text { Worcestershire } \\
\text { and Warwickshire }\end{array}$ & 95.68 & 54.95 & 109.72 & 55,571 & 31,913 & 63,725 \\
\hline North Yorkshire & 95.16 & 54.60 & 108.68 & 34,543 & 19,820 & 39,451 \\
\hline $\begin{array}{l}\text { North Eastern } \\
\text { Scotland }\end{array}$ & 95.16 & 54.77 & 108.68 & 21,563 & 12,412 & 24,627 \\
\hline $\begin{array}{l}\text { Cornwall and } \\
\text { Isles of Scilly }\end{array}$ & 94.64 & 54.43 & 108.68 & 24,398 & 14,031 & 28,018 \\
\hline $\begin{array}{l}\text { West Wales and } \\
\text { The Valleys }\end{array}$ & 94.64 & 54.08 & 108.16 & 81,807 & 46,747 & 93,494 \\
\hline
\end{tabular}




\begin{tabular}{llll|rrr|}
$\begin{array}{l}\text { Shropshire and } \\
\text { Staffordshire }\end{array}$ & 94.12 & 54.08 & 107.64 & 64,670 & 37,158 & 73,959 \\
\hline $\begin{array}{l}\text { Dorset and } \\
\text { Somerset }\end{array}$ & 93.08 & 53.04 & 106.60 & 54,992 & 31,336 & 62,979 \\
\hline United Kingdom & 97.76 & 56.16 & 111.28 & $2,818,431$ & $1,619,098$ & $3,208,214$ \\
\hline
\end{tabular}

Note: differences among the national values estimation and the sum of single regional values are due to computational approximations,

Source: REFRESH Road Map

The predicted food waste for United Kingdom, considering the actual regional values for GDP per capita and higher education level amounts to $\mathbf{9 7 . 7 6} \mathrm{kg}$ per household and an overall total of almost $\mathbf{2 , 8 1 8 , 4 3 1}$ tons per year,

At the regional level, the lowest estimated values of food waste are registered in Dorset and Somerset, with an average household FW of $\mathbf{9 7 . 7 6} \mathrm{kg}$ per year, while the highest are recorded in Inner London - East, with a value of $\mathbf{1 0 3 . 4 8} \mathrm{kg}$ per year. 


\section{References}

Canali, M., Amani, P., Aramyan, L., Gheoldus, M., Moates, G., Östergren, K., Silvennoinen, K., Waldron, K., Vittuari, M., 2016. Food Waste Drivers in Europe, from Identification to Possible Interventions. Sustainability 9, 37. https://doi.org/10.3390/su9010037

Grainger, M., Piras, S., Righi, S., Setti, M., Stewart, G., Vittuari, M., 2018. Behavioural economics: Linking Bayesian and agent-based models to assess consumer food waste.

Parfitt, J., Barthel, M., Macnaughton, S., 2010. Food waste within food supply chains: quantification and potential for change to 2050. Philos. Trans. R. Soc. B Biol. Sci. 365, 3065-3081. https://doi.org/10.1098/rstb.2010.0126

Piras, S., Righi, S., Setti, M., Vittuari, M., 2016. Business behavioural typologies and interrelationships. Implications for food waste.

Reynolds, C., Goucher, L., Quested, T., Bromley, S., Gillick, S., Wells, V.K., Evans, D., Koh, L., Carlsson Kanyama, A., Katzeff, C., Svenfelt, A.,, Jackson, P., 2019. Review: Consumption-stage food waste reduction interventions - What works and how to design better interventions. Food Policy 83, 7-27. https://doi.org/10.1016/j.foodpol.2019.01.009

Stenmarck, §., Jensen, C., Quested, T., Moates, G., 2016. Fusions: Estimates of European food waste levels.

Van Geffen, L., Van Herpen, E., Van Trijp, H., Quested, T., Díaz-Ruiz, R., 2017. Quantified consumer insights on food waste Pan-European research for quantified consumer food waste understanding. EU Refresh Proj.

WRAP, 2013. Household food and drink waste in the UK 2012 | WRAP UK [WWW Document]. URL http://www.wrap.org.uk/content/householdfood-and-drink-waste-uk-2012 (accessed 4.8.19). 